

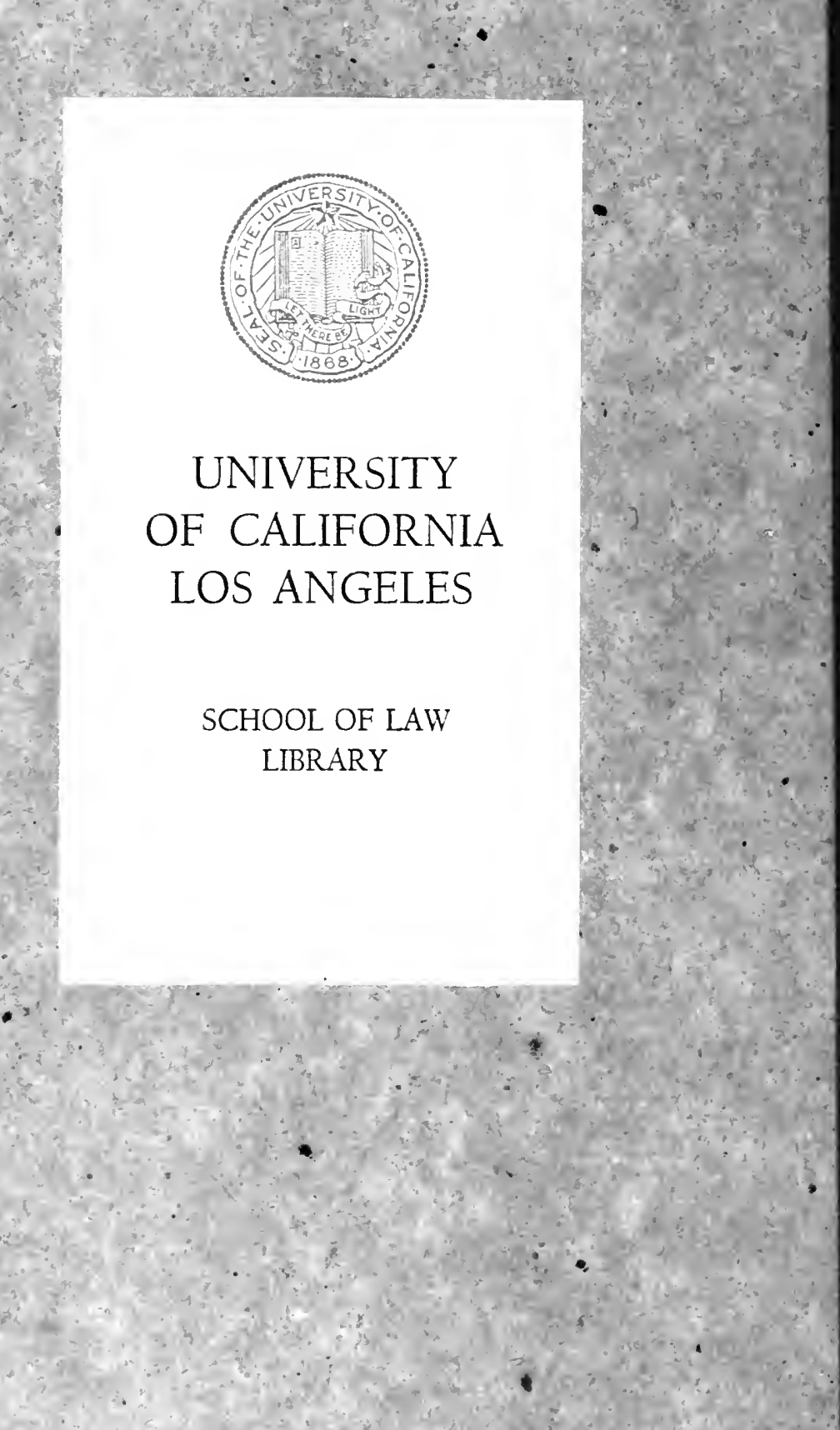

SCHOOL OF LAW LIBRARY 


\title{
STUDIES IN THE POLICE POWER OF THE NATIONAL GOVERNMENT
}

\author{
by \\ ROBERT EUGENE CUSHMAN \\ "1! \\ Associate Professor of Political Science, \\ University of Minnesota.
}

Reprinted from the Minnesota Law Review,

Vol. III, Nos. 5, 6, and 7, April, May and June, 1919,

Vol. IV, Nos, 4 and 6, March and May, 1920. 


$$
\begin{aligned}
& T \\
& C 95965 \\
& 1920
\end{aligned}
$$




\title{
THE NATIONAL POLICE POIVER
}

\author{
UNDER THE
}

\section{COMMERCE CLAUSE OF THE CONSTITUTION}

To point out to the man in the street that while the Congress of the United States may pass laws to suppress the white slave traffic or the sale of adulterated food, it has no power to prohibit child-labor or to regulate marriage and divorce, does not add much to his understanding of American constitutional law. Too often it merely decreases his respect for the constitution and the courts which construe it. His feeling is one of exasperation that any truly national need should exist, any national problem should cry for solution, and the national legislature should lack the authority to deal with it:

The point of view of the layman emphasizes in striking fashion the completeness with which, as a people, we have been won over more or less unconsciously to the belief that Congress has, or ought to have, authority to pass any salutary law in the interest of the national welfare. Instead of surprise that Congress should have the temerity to penetrate into a new field of legislation, there is impatience to find that there is any such field into which Congress may not penetrate. It is the purpose of this article to restate some fundamental doctrines of our constitutional law and review some of the steps in our constitutional history with a view to making clear the somewhat precarious trial and error process by which Congress has come gradually to legislate in affairs over which it has been supposed to have no jurisdiction 
-to assume responsibility for the safety, health, morals, good order, and general welfare of the nation, and thus to exercise what may be called a national police power.

It seems clear that it is entirely proper to use the term "national police power." To borrow a definition of the police power from the authority perhaps most competent to lend, ${ }^{1}$ it is that power of government which "aims directly to secure and promote the public welfare" by subjecting to restraint or compulsion the nembers of the community. It is the power by which the government abridges the freedom of action or the free use of property of the individual in order that the welfare of the state or nation may not be jeopardized. It is obvious, then, that when Congress places a prohibitive tax upon poisonous matches, excludes obscene literature from the mails, or enacts an employers' liability law, it is exercising police power. What is the source and nature of this police power which Congress enjoys and what are the limitations upon it?

\section{Theory of the National Police Power \\ Principle of Enumerated Powers of Congress}

To understand clearly the nature of the national police power it is necessary to bear in mind one of the a b c's of our constitutional law, namely, that Congress enjoys those powers of legislation, and only those, which are positively given to it by the constitution. Unlike the states, which enjoy all powers which have not been taken away from them, it has only the powers which are delegated to it. The subjects over which it may exercise control are carefully enumerated. It would be useless to argue a point so firmly established. Nothing is clearer than that the purpose of the Convention of 1787 was to confer upon the new Congress a certain group of powers definitely delimited and to leave the other powers of government in the hands of the states. Hamilton's famous argument in the Federalist ${ }^{2}$ against the adoption of a bill of rights to the new constitution urged, it will be recalled, that to add to the constitution a list of things which Congress might not do, when Congress had never been given power by the constitution to do them, savored of the dangerous

\footnotetext{
${ }^{1}$ Freund, Police Power, Sec. 3.
}

2 Federalist, No. 84. 
doctrine that Congress enjoyed powers not positively granted to it provided they had not been specifically denied to it. Any such danger was, of course, obviated by the Tenth Amendment declaring that "the powers not delegated to the United States by the Constitution, nor prohibited by it to the States, are reserved to the States respectively, or to the people"; and since that time commentators and courts have joined with complete unanimity in making the doctrine that the powers of Congress are enumerated powers a constitutional axiom. ${ }^{3}$

The effect of this doctrine of enumerated powers upon the right of Congress to exercise a national police power is perfectly plain. The enumeration of congressional powers in the constitution does not include any general grant of authority to pass laws for the protection of the health, morals, or general welfare of the nation. ${ }^{4}$ It follows, then, that if Congress is to exercise a police power at all it must do so by a process soniething akin to indirection; that is, by using the powers which are definitely confided to it, for the purposes of the police power. If it would enter upon an ambitious program to protect public morals or safety or health or to promote good order, it must cloak its good works under its authority to tax, or to regulate commerce, or to control the mails, or the like, and say, "By this authority we pass this law in the interest of the public welfare." In short, Congress exercises a generous police power not because that power is placed directly in its hands but because it has the power to regulate commerce, to lay taxes, and to control the mails, and uses that authority for the broad purposes of the general welfare. ${ }^{5}$

3 "The constitution was, from its very origin, contemplated to be the frame of a national government, of special and enumerated powers. This is apparent, as will presently be seen from the history of the proceedings of the convention which framed it; and it has formed the admitted basis of all legislative and iudicial reasoning upon it ever since it was put in operation, by all who have been its open friends and adrocates as well as by all who have been its enemies and opponents." Story. Constitution, 5 th el., I, Sec. 909.

${ }^{4}$ Sec. 8 , Art. I, of the constitution reads: "The Congress shall have nower to lay and collect Taxes. Duties. Imposts and Excises, to pay the Debts and provide for the common Defense and general Welfare of the United States; . . ." It has been generally agreed. however, that this clause does not confer a general police power upon Congress, but merely the power of levying taxes, etc., for the purpose of paying the debts and providing for the common defense and general welfare of the country. For elaborate review of the authorities on this point, see Watson. Con. stitution. I, p. 390 et seq.

5 This point is further emphasized and the practice severely criticized in an illuminating article by Judge Charles M. Hough, Covert Legislation 
That Congress can exercise police power only in so far as it is possible to utilize one of its enumerated powers for that purpose is not due to accident or inadvertence. The limited nature of that police power has been emphasized and re-emphasized by the unsuccessful efforts of those who from 1787 to the present time have sought to secure its enlargement and invest Congress with a power adequate to deal with any truly national problem. The earliest of these efforts was made in the Convention of 1787 . Four resolutions were introduced during the sessions of that body, varying somewhat in phraseology but similar in purpose. ${ }^{6}$ That purpose, to quote the language of the one introduced by $\mathrm{Mr}$. Bedford, was to confer upon Congress the power "to legislate in all cases for the reneral interests of the Union, and also in those to which the States are severally incompetent, or in which the harmony of the United States may be interrupted by the exercise of individual legislation." In defeating these resolutions the Convention passed squarely upon the question whether or not Congress should enjoy a general police power for the protection of the national welfare apart from its specifically enumerated powers and decided that it should not.

There is a difference of opinion among historians and commentators as to whether James Wilson actually held to the doctrine that Congress possessed any general unenumerated powers. Certain utterances of his have, however, been quoted to prove that he held this view; and more than a century later President Roosevelt used him as an authority in support of his famous doctrine of "New Nationalism." In 1785 Wilson referred to the powers of Congress under the Articles of Confederation in the following language: "Though the United States in congress assembled derive from the particular States no power, jurisdiction, or right which is not expressly delegated by the confederation, it does not thence follow that the United States in congress have no other powers, jurisdiction, or rights, than those delegated by the particular states. The United States have general rights, general powers, and general obligations, not derived

and the Constitution, (1917) 30 Harv. Law Rev. 801. See also an article by Paul Fuller, Is There a Federal Police Power? (1904) 4 Col. Law Rev. 563.

${ }^{6}$ Farrand. Records of the Federal Convention of 1787. I. p. 229: II, pp. 25, 26, 367. The first of these was the sixth resolution in the report of the Committee of the Whole; the others were introduced by Sherman, Bedford, and Rutledge, respectively. 
from any particular state, nor from all the particular states, taken separately; but resulting from the union of the whole. . . To many purposes the United States are to be considered as one undivided, independent nation; and as possessed of all the rights, and powers, and properties by the law of nations incident to such. Whenever an object occurs, to the direction of which no particular state is competent, the management of it must, of necessity, belong to the United States in congress assembled. There are many objects of this extended nature." If such a construction could be placed upon the powers of the congress of the Confederation, powers which were not only delegated but expressly delegated, then surely the same construction could be placed, a fortiori, upon the powers of Congress under the present constitution, which omits the word "expressly." When the federal constitution was before the Pennsylvania convention for ratification Wilson, who was a member of that body, made a speech in which he declared that the framers of the constitution in drawing a line between the powers of the national government and those of the states had acted upon the principle that "Whatever object of government is confined in its operation and effect within the bounds of a particular state, should be considered as belonging to the government of that state; whatever object of government extends in its operations or effects beyond the bounds of a particular state, should be considered as belonging to the government of the United States."'s Although this statement might lend support to the view that Congress could deal with national problems because they were national even in the absence of a positive grant of authority to do so, it seems hardly necessary to regard it in any other light than as a simple statement of the object which the Convention tried to attain in the matter of distributing powers between the nation and the states. Without speculating further on the actual significance of the statements quoted, it may be noted that no trace is found of the so-called "Wilson Doctrine" in Wilson's judicial utterances, nor is there other evidence that he ever became an active exponent of that principle. ${ }^{9}$

${ }^{7}$ Considerations on the Power to Incorporate the Bank of North America, Wilson's Works, Andrews' ed., I, pp. 557, 558.

8 Ibid., p. 533 .

${ }^{9}$ In support of the so-called Wilson doctrine, see: L. H. Alexander, James Wilson, Patriot, and the Wilson Doctrine, North Am. Rev. vol. 183 , p. 971; Governor Samuel W. Pennypacker, Address at Wilson Memorial 
It remained for President Roosevelt to discover or at least to label the neutral or "twilight" zone in our constitutional system - a zone lying between the jurisdictions of the state and the nation, to which lawbreakers of great wealth might repair and be free from punishment or restraint. Large corporations had come to be beyond the reach of the state because they had grown to national dimensions; they were outside the effective control of Congress because the constitution does not confer upon Congress a positive grant of authority to deal with them directly. It was to meet this situation that President Roosevelt urged his doctrine of "New Nationalism," first as a principle of constitutional interpretation, and, failing in that, as a constitutional amendment. That doctrine may be best stated in his own words: "It should be made clear that there are neither vacancies nor interferences between the limits of state and national jurisdictions, and that both jurisdictions together compose only one uniform and comprehensive system of government and laws; that is, whenever the states cannot act, because the need to be met is not one merely of a single locality, then the national government, representing all the people, should have complete power to act." ${ }^{\prime \prime}$ In public addresses delivered after 1906 President Roosevelt reverted again and again to this subject, urging always that the federal government should be competent to deal with every truly national problem and expressing his impatience at "the impotence which springs from overdivision of government powers, the impotence which makes it possible for local selfishness or for legal cunning, hired by wealthy special interests, to bring national activities to a deadlock." 11

But if this "New Nationalism" is ever to be incorporated into our constitutional law it will need to be by a constitutional amendment. In the case of Kansas $v$. Colorado, decided in $1907,{ }^{12}$ the Supreme Court was invited to adopt that doctrine in construing the powers of Congress, but it declined in no

Services, (1906) 55 Am. Law Reg. p. 13; President Roosevelt, speech at dedication of Pennsylvania state capitol, quoted and discussed in Willoughby, Constitution, I, p. 48. The doctrine is criticized by Edward Lindsay in Wilson Versus the "Wilson Doctrine," 44 Am. Law Rev. p. 641.

10 From his speech at Ossawatomie, Kansas, August 31, 1910.

$11 \mathrm{Idem}$. The doctrine of "New Nationalism" is discussed and criticized in Willoughby, Constitution, I, pp. 48-66.

12 (1907) 206 U. S. 46, 51 L. Ed. 956, 27 S. C. R. 655. 
uncertain language to do so. It was urged upon the court in that case that Congress had a paramount right to control the whole system of reclaiming arid lands in a state, whether owned by the United States or not, on the theory that "all powers which are national in scope must be found vested in the Congress of the United States." "Such a view the court held to be in direct conflict with the general established doctrine that the national government is a government of enumerated powers and also with the specific provisions of the Tenth Amendment. "This amendment," declared the court, "which was seemingly adopted with prescience of just such contention as the present, disclosed the widespread fear that the national government might, under the pressure of a supposed general welfare, attempt to exercise powers which had not been granted. With equal determination the framers intended that no such assumption should ever find justification in the organic act, and that if, in the future, further powers seemed necessary, they should be granted by the people in the manner they had provided for amending that act. It reads: "The powers not delegated to the United States by the Constitution, nor prohibited by it to the States, are reserved to the States respectively, or to the people.' The argument of counsel ignores the principal factor in this article, to wit, 'the people.' Its principal purpose was not the distribution of power between the United States and the states, but a reservation to the people of all powers not granted." It would seem from this opinion that President Roosevelt's "twilight zone" is firmly intrenched in our constitutional system and that those who hope to develop a national police power by interpretation or by any method but amendment are doomed to disappointment. ${ }^{13}$

\section{Principle of Implied Powers}

It is perfectly certain that under the doctrine that Congress has no powers which are not enumerated in the constitution it would have been quite impossible to develop a national police

13 This doctrine of a general, inherent, unenumerated power of Congress is not to be confused with what Story termed "resulting powers," or those deduced from several or all of the enumerated powers of Congress. See Commentaries, 5th ed., II, Sec. 1256. Among the examples of such "resulting powers" are the power to exercise the right of eminent domain, Kohl v. United States, (1875) 91 U. S. 367, 23 L. Fd. 449; the power to issue legal tender notes, Juilliard v. Greenman, (1884) $110 \mathrm{U}$. S. 421, $28 \mathrm{~L}$. Ed. 204, 4 S. C. R. 122; and the power to exclude aliens, Fong Yue Ting v. United States, (1893) 149 U. S. 698. 37 L. Ed. 905, 13 S. C. R. 1016. See Willoughby, Constitution, I, Secs. 37, 38. 
power were it not for the fact that the scope of congressional authority was vastly increased, and the possibility of ever-multiplying extensions of power opened up, by the establishment upon a firm foundation of the so-called doctrine of implied powers. It will be recalled that under the Articles of Confederation "Each State retains its sovereignty, freedom, and independence, and every power, jurisdiction, and right, which is not by this confederation expressly delegated to the United States in Congress assembled." 14 When the Tenth Amendment was being debated by Congress in 1789 a motion was made to insert there also the word "expressly" before the word "delegated." This motion, however, was rejected. ${ }^{15}$ The bitter controversy which raged between the Federalists and the anti-Federalists as to whether or not Congress might exercise powers which were not expressly conferred was not settled finally and authoritatively until Marshall's famous opinion in 1819 in the case of McCulloch $v$. Maryland. ${ }^{16}$ It was in that opinion that Marshall gave his classic statement of the doctrine of implied powers: "Let the end be legitimate, let it be within the scope of the Constitution, and all means which are appropriate, which are plainly adapted to that end, which are not prohibited, but are consistent with the letter and spirit of the Constitution, are constitutional." Thus the ghost of strict construction was laid forever, at least so far as the Supreme Court was concerned; and in 1884.Mr. Justice Miller, by way of giving it a suitable epitaph, took occasion to allude to "the old argument, often heard, often repeated, and in this court never assented to, that when a question of the power of Congress arises the advocate of the power must be able to place his finger on the words which expressly grant it."'17 .

Thus it will be seen that while the doctrine of enumerated powers imposes upon Congress the necessity of finding among its delegated powers what has been aptly termed "a definite constitutional peg" upon which to hang every exercise of the national police power, the doctrine of implied powers, or the liberal construction of congressional authority, has made it possible to hang upon those "pegs" an enormous amount of salutary legislation in the interest of the national health, safety, and well being. The

14 Art. II. Italics are the author's.

15 Annals of Congress, I, p. 768.

16 (1819) 4 Wheat. '(U.S.) 316. R. 152 .

17 Ex parte Yarbrough. (1884) 110 U. S. 651, 658, 28 L. Ed. 274, 4 S. C. 
"pegs" themselves are few in number, the only important ones being the power to regulate commerce, the power to tax, and the power to establish and run the postal system; but the police legislation which they have been made to support deals with anything from the white slave traffic to speculation in cotton.

\section{Limitations on the National Police Power}

In the exercise of its police power Congress is subject to three definite constitutional limitations. The first of these limitations has already been outlined: Congress must, in passing police legislation, use an enumerated power; in other words, there must always be a constitutional peg. This would seem on first thought to be entirely obvious. Yet occasionally Congress has tried, always unsuccessfully, to do without the peg. In 1867 Congress forbade the sale of illuminating oils which were below a certain fire test. ${ }^{18}$ The law was declared invalid because it was entirely unrelated to any of the delegated powers ${ }^{19}$ of Congress. It was not a regulation of interstate commerce; it was not a tax; and Congress did not pretend that it was. For the same reason the act of 1876 punishing the counterfeiting of trademarks and the sale of counterfeit trademark goods ${ }^{20}$ was declared unconstitutional. ${ }^{21}$ The excerpt quoted above ${ }^{22}$ from the opinion of the court in Kansas $v$. Colorado emphasizes the same point. In all of these cases Congress had tried to pass police regulations without finding a constitutional peg on which to hang them.

The second limitation requires that a real relevancy exist between the police regulation and the peg upon which. it is hung. Assuming that Congress in exercising its police power uses one of its delegated powers and labels its act accordingly as a tax law, a regulation of commerce, or the like, the law must then pass the test: is there a reasonable enough connection between the law Congress has passed and the constitutional grant of power on which Congress has relied in passing it to warrant its being regarded as a regulation of commerce, or the mails, or the like? If our courts

18 Act of March 2, 1867, Chap. 169 Sec. 29, 14 Stat. at L. 484.

19 United States v. De Witt, (1870) 9 Wall. (U.S.) 41 . The title of the act was "An Act to amend existing Laws relating to Internal Revenue, and for other Purposes." The section involved here must liave been one of those passed "for other purposes," for it made no reference to any tax.

20 Act of August 14, 1876. 19 Stat. at L. 141.

21 Trade-Mark Cases, (1879) 100 U. S. 82, 25 L. Ed. 550.

22 Supra, p. 295. 
in determining the validity of legislation took account of the motives of law-makers, these motives would in the main tend to become the test of the validity of the law; but since the courts ignore those motives and take legislation at its face value, the relevancy of the law to its label becomes the test. In other words, it is proper enough for Congress to use its power over interstate commerce as a means of protecting the national health or morals; but Congress must not get so absorbed in the work of protecting the national health or morals that it forgets that it is, after all, supposed to be regulating interstate commerce. When this test was applied to the law passed in 1907 by which Congress made it a felony for any person to harbor an alien prostitute within three years after her entrance into this country, ${ }^{23}$ the court found that while the authority of Congress to regulate immigration was undoubted and while the law of which the provision in question was a part was entitled "An Act to Regulate the Immigration of Aliens into the United States," nevertheless that provision did not as a matter of fact regulate immigration. ${ }^{24}$ "The validity of the provision in question," declared the court, "should be determined from its general effect upon the importation and exclusion of aliens. But it is sufficient to say that the act charged has no significance in either direction." The provision was invalid because it did not bear a sufficiently close relation to anything over which the constitution gives Congress authority to act. In a case which will be discussed at a later point ${ }^{25}$ it was held that the provision of the Erdman Act forbidding interstate carriers to discharge employees because of membership in labor organizations was not a legitimate exercise of congressional authority because there was no connection between interstate commerce and membership in a labor union. ${ }^{26}$ In the other cases which will be considered in the course of this article it will be seen that no law which Congress has passed in the exercise of a national police power has been upheld unless the court has, after careful scrutiny of this point,

23 Act of February 20, 1907, 34 Stat. at L. 898.

24 Keller v. United States, (1909) 213 U. S. 138, 53 L. Ed. 737, 29 S. C. R. 470, 16 Ann. Cas. 1066.

25 Adair v. United States, (1908) 208 U. S. 161, 52 L. Ed. 436, 28 S. C. R. 277, 13 Ann. Cas. 764. See infra, pp. 308, 317.

${ }_{26}$ Professor Goodnow takes the view that this part of the opinion is dictum, since the court had already declared the provision under consideration to be a violation of the due process of law clause of the Fifth Amendment. Social Reform and the Constitution, 81 et seq. 
been convinced that the law was at the same time a real and substantial exercise of one of the enumerated powers of Congress.

The third limitation, or set of limitations, upon the national police power is to be found in the specific prohibitions upon congressional authority contained in the constitution and particularly in the bill of rights. These restrictions operate in a perfectly obvious and direct fashion. Congress may use its delegated powers for the protection of the national welfare; but in so doing it must not take life, liberty, or property without due process of law, take private property for public use without just compensation, interfere with religious liberty, or do any of those things which it is definitely forbidden by the constitution to do. This third limitation rests upon the well-established principle that the specific prohibitions of the constitution act as restraints upon the general grants of powers to Congress. $^{27}$ The restriction of due process of law is the one perhaps most commonly enforced against exercises of the national police power, particularly those passed under the commerce clause; but in the exercise of the power over the postal system for the protection of the national morals or safety the question has sometimes arisen whether or not Congress has violated the guarantees of freedom of the press, or the guarantee against unreasonable searches and seizures. ${ }^{28}$

In the light of the foregoing constitutional principles and limitations, it is the purpose of the present article to discuss the police power which Congress has exercised under the grant of authority to regulate commerce; and to mark out the scope and variety of the protection which has been accorded the national safety, health, morals, and general welfare in this somewhat indirect and roundabout way.

\section{General Nature and Scope of the Commerce Power}

If one were obliged to name the most potent cause leading to the calling of the Convention of 1787 he would not hesitate in choosing the need for a national control over foreign and inter-

${ }^{27}$ Story, Constitution, II, Sec. 1864 et seq. Monongahela Navigation Co. v. United States, (1893) 148 U. S. 312, 336, 37 L. Ed. 463,13 S. C. R. 622.

28 Ex parte Jackson, (1877) 96 U. S. 727. 24 L. Ed. 877; In re Rapier, (1892) 143 U. S. 110, 36 L. Ed. 93, 12 S. C. R. 374 ; Lewis Publishing Co. v. Morgan, (1913) 229 U. S. 288,57 L. Ed. 1190, 33 S. C. R. 867 ; Public Clearing House v. Coyne, (1904) 194 U. S. 497; 48 L. Ed. 1092, 24 S. C. R. 789. 
state commerce. That there was scant discussion of the problem in the Convention was perhaps due to the unanimity of conviction among the members of that body that the power to regulate commerce should unquestionably rest in the new Congress. Since the adoption of the constitution no small part of the time of Congress has been occupied with the exercise of this power, and no small part of the time of the Supreme Court has been spent in passing upon the constitutionality and meaning of those laws. Considering the wide range of instrumentalities and transactions which have come to be included in the term commerce it is but natural that the authority to regulate it should serve as the constitutional basis for the development of a wide national police power.

The constitution confers upon Congress the power to regulate three kinds of commerce: first, "with foreign nations," second, "among the several states," and third, "with the Indian tribes." The power given in respect to each of these is the same, that is, the power to "regulate"; and there is nothing in the language used to indicate that the framers of the constitution had in mind any distinctions as to the extent of the power of Congress over each type. Congress early utilized its authority over these different classes of commerce, however, in different ways, to meet widely different problems, and apparently without stopping to discuss whether its power over one was greater than over another. It was not until railroad transportation reached a high point of development that Congress, a full century after the framing of the constitution, began to turn its mind seriously to the problems of interstate commerce regulation. But in the meantime the regulations of foreign and Indian commerce had been numerous and rigorous in character. The question has, therefore, become pertinent whether Congress actually does have exactly the same power over interstate commerce that it enjoys over commerce with foreign nations and with the Indian tribes, or whether that power is more restricted. Especially has it been repeatedly urged by those interested in the expansion of a national police power that Congress could exercise every power over interstate commerce which it could exert in controlling foreign commerce. ${ }^{30}$

${ }^{29}$ A.rt. I, Sec. 8.

30 This position has been taken, for instance, by those who believe that Congress may restrict child-labor by means of its control over inter- 
It is possible to cite several cases in which the Supreme Court has expressed the opinion that there is no difference between the powers of Congress over foreign and interstate commerce. ${ }^{31}$ Marshall voiced this view in Gibbons v. Ogden, ${ }^{32}$ and in $1888 \mathrm{Mr}$. Justice Mathews in Bocuman v. Chicago, etc., Ry. Co. declared, "The power conferred upon Congress to regulate commerce among the States is indeed contained in the same clause of the Constitution which confers upon it power to regulate commerce with foreign nations. The grant is conceived in the same terms, and the two powers are undoubtedly of the same class and character and equally extensive." ${ }_{33}$ While these statements sound perfectly conclusive and final, the fact remains that in passing upon the validity of several of the congressional police regulations over interstate commerce the court, though urged to do so, has steadily declined to uphold such regulations on the ground that similar police restrictions applicable to foreign commerce have been sustained. $^{34}$ A substantial body of opinion has grown up in support of the view that there is, after all, a difference between the two powers. It is urged by an eminent authority that "although the three classes of commerce are thus included in the same clause and in the same terms in the enumeration of powers, they are clearly distinguishable in their historic setting and constitutional import, and the laws which are necessary and proper in regulating commercial intercourse with foreign nations and with the Indian tribes may not be necessary and proper in regulating such commercial intercourse between the states." ${ }_{35}$ Without anticipating the more detailed discussion of this problem appropriate at a later point in this article, it may be suggested that Congress has actually exercised a police power over foreign commerce which there is reason to believe would be regarded as beyond its proper authority if applied to commerce among the several states. And while there is no authoritative judicial pronouncement upon this question, an authority over interstate commerce which does not

state commerce. This point will be further considered in a later section of this article.

31 For citation of these cases, with comment, see note by E. B. Whitney, 7· Yale Law Jour. 294.

32 (1824) 9 Wheat. (U.S.) 1, 228, 6 L. Ed. 23.

33 (1888) 125 U. S. 465. 482, 31 L. Ed. 700, 8 S. C. R. 689.

34 This was true both in the Lottery Case and in the recent child-labor case; it will be treated more fully in connection with the latter case.

35 Judson, Interstate Commerce, 3rd ed., Sec. 6. 
extend to the exclusion from the channels of that commerce of the products of factories employing child-labor ${ }^{36}$ can hardly be called co-extensive with an authority over foreign commerce which excludes from our shores the products of convict-labor. ${ }^{37}$

The relationship between the national government and the Indians has always been regarded as anomalous, and it would be unprofitable to enter upon any extended comparison of the power of Congress over interstate commerce with that over commerce with the Indian tribes. Our control over these people has been paternalistic in character. ${ }^{38}$ Because of the importance and delicacy of the problem, Congress has regulated intercourse with the Indians with a rigorous hand. It has forbidden commercial dealings with them in certain commodities, as, for example, intoxicating liquors; ${ }^{39}$ and has even gone to the length of forbidding any one to trade with them without a license issued by the federal government. ${ }^{40}$ It seems probable that restraints have been placed upon commerce with the Indians which could not be imposed upon ordinary trade relations between citizens of the states.

The following discussion of the police power which Congress has come to exercise under the commerce clause may properly be confined, therefore, to the problems relating to interstate commerce. This is appropriate not only because it is in that field of regulation that the national police power has developed in most striking and most varied form, but also because the preceding paragraphs make it clear that if there is any constitutional distinction among the powers of Congress over foreign, interstate, and Indian commerce the power over interstate commerce is the most narrowly restricted; and accordingly whatever police power Congress may exercise over interstate commerce it may exercise over foreign and Indian commerce.

36 Hammer v. Dagenhart, (1918) 247 U. S. 251, 38 S. C .R. 529.

37 Act of October 3, 1913, 38 Stat. at L. 195. The validity of this law has never been questioned and would seem, in the light of numerous precedents, to be unquestionable.

38 Matter of Heff, (1905) 197 U. S. 488, 498, 49 L. Ed. 848, 25 S. C. R. 501 (overruled in United States v. Nice, [1916] 241 U. S. 591, 36 S. C. R. 696).

${ }^{39}$ Held valid in United States v. Holliday, (1866) 3 Wall. (U.S.) 407 , 18 L. Ed. 182: United States v. Forty-three Gallons of Whiskey, (1876) 93 U. S. 188, 23 L. Ed. 846.

${ }^{40}$ Upheld in United States v. Cisna, (1835) 25 Fed. Cas. 422. See Act of March 3, 1903, 32 Stat. at L. 1009. 
While the police regulations which Congress has passed under its authority to regulate interstate commerce have been exceedingly numerous and have dealt with a wide range of topics, from locomotive ashpans to obscene literature, they may all be placed for convenience in four groups, according to the general purpose of their enactment and the constitutional principles upon which they are based. (I) In the first group may be placed those regulations in which Congress has exercised police power for the protection and promotion of interstate commerce itself by the enactment of such laws as the safety appliance acts, the anti-trust acts, and other regulations designed to keep that commerce safe, efficient, and unobstructed. (II) The second group comprises the cases in which the law forbids the use of interstate commerce as a medium or channel for transactions which menace the national health, morals, or welfare. In this class would be placed the Pure Food Act, the White Slave Act, and other statutes by which Congress, instead of protecting commerce itself from danger, protects the nation from the misuse of that commerce. (III) The third group consists of the enactments by which Congress co-operates with the states by forbidding the use of the facilities of interstate commerce for the purpose of evading or violating state police regulations. Here would be found such laws as the WebbKenyon Act, excluding from interstate commerce shipments of liquor consigned to dry territory. (IV) In the last group should be placed the Keating-Owen Child-Labor Act of 1916, by which Congress attempted to deny the privileges of interstate commerce to articles produced under conditions which Congress disapproved but which it had no direct power to control. Careful consideration may profitably be given to each of these groups.

\section{National Police Power for Promotion and Protection OF COMMERCE}

1. Appliances and Physical Regulations Necessary for Safety. It is but natural that Congress should feel that one of the most obvious and necessary duties imposed upon it by the grant of power to regulate commerce is the duty to pass police regulations to protect from destruction, loss, or danage the lives, limbs, and property of persons concerned in the processes or transactions of interstate commerce, whether as passengers, shippers. or em- 
ployees. As early as 1838 laws were passed requiring the installation of safety devices upon steam vessels. ${ }^{41}$ Beginning with a statute passed in 1866 Congress has rigorously controlled the transportation on land and water of explosives. ${ }^{42}$ But it was not until 1893 that Congress began to enact the comprehensive set of safety appliance acts now applicable to interstate railroads. ${ }^{43}$ The first of these acts was the Automatic Coupler Act, ${ }^{44}$ which has been supplemented by more recent laws requiring, among other things, the use of ashpans ${ }^{45}$ on locomotives, the inspection of boilers, ${ }^{46}$ and the use of ladders, hand-brakes, drawbars, and similar devices on cars. ${ }^{47}$ To the same general purpose are the statutes requiring railroads to make full reports to the Interstate Commerce Commission regarding all accidents. ${ }^{48}$ A statute of 1913 protects interstate commerce from another type of loss by making criminal the unauthorized breaking of the seals of railroad cars containing interstate or foreign shipments. ${ }^{49}$

The purpose of Congress in passing these laws is perfectly plain. Most of them, following the pioneer Safety Appliance Act of 1893, declare specifically that their object is "to promote the safety of employees and travellers upon railroads." The courts have uniformly recognized this purpose. "The Safety Appliance Act," declares one federal judge, "is essentially a police regulation. Its general purpose is humanitarian-the safeguarding of employees from injury and death." ${ }_{50}$ In the words of another court, "the object of Congress in passing the safety appliance acts was undoubtedly to safeguard interstate commerce, the life of the passengers, and the life and limb of the employees

41 Act of July 7, 1838, 5 Stat. at L. 304 ; Act of March 3, 1843, ibid., 626.

42 Act of July 3,1866, 14 Stat. at L. 81. For legislation on this subject now in force. see the U. S. Criminal Code of March 4, 1939, 35 Stat. at L. 1134, Secs. 232-236.

43 Collected in Comp. Stat. 1918, Secs. $8605-8650 ; 3$ U. S. S. A. 480-530.

44 Act of March 2, 1893, 27 Stat. at I. 531.

45 Act of May 30, 1908, 35 Stat. at L. 476.

46 Acts of February 17, 1911, 36 Stat. at L. 913, and March 4, 1915, 38 ibid., p. 1192.

47 Act of April 14, 1910, 36 Stat. at L. 298.

48 Act of May 6, 1910, 36 Stat. at L. 351; Act of February 17, 1911, ibid., p. 216.

49 Act of February 13. 1913, 37 Stat. at L. 670. Upheld in Morris v. United States, (1916) 229 Fed. 516.

50 United States v. Philadelphia, etc., Ry. Cc '191' 223 Fed. 215, 216. 
engaged therein." purpose of this legislation to be "to promote the public welfare by securing the safety of employees and travellers."

That these statutes designed to insure the physical safety of interstate commerce are police regulations falling well within the recognized limits of congressional power is too obvious to call for argument; so obvious, in fact, that the Supreme Court has never been asked to decide a case in which it was squarely contended that acts of this kind were not natural and legitimate regulations of commerce. ${ }^{53}$ Moreover, in several cases involving the meaning and application of these statutes, as well as in cases involving analogous exercises of the commerce power, that tribunal has alluded to the safety appliance acts in terms which place the question of their validity in the realm of settled law. ${ }^{54}$ And indeed if the power to regulate commerce does not include the power to make reasonable rules to secure the physical safety of the lives and property of travellers, shippers, and employees, it may well be inquired what conceivable kind of commercial regulation could be regarded as legitimate.

2. Regulations of Labor Necessary for Safety of Interstate Commerce. (a) Hours of Service Act: It came at last to be recognized that safety appliances and regulations were not enough in and of themselves to insure the physical safety of interstate commerce. There were plenty of gruesome proofs of the fact that life and property on interstate railroads were as much jeopardized by the deadening fatigue of a locomotive engineer as by the absence of block signals or automatic couplers. Accordingly, in 1907 Congress passed the Hours of Service Act, ${ }^{55}$ making it unlawful for any interstate carrier to employ a train-

51 United States v. Atl. Coast Line R. Co.. (1913) 214 Fed. 498, 499.

52 Johnson v. So. Pacific Co., (1904) 196 U. S. 1, 17, 49 L. Ed. 365, 25 S. C. R. 158 .

53 The validity of these laws has been passed upon squarely, however, in numerous decisions of the lower federal courts. For extensive citation of cases, see Thornton. The Federal Employers' Liability Act, 3rd ed., p. 334: Richey, Federal Employers' Liability, Safety Appliance, and Hours of Service Acts, 2nd ed., Sec. 215.

54 Johnson v. So. Pacific Co.. supra ; Schlemmer v. Buffalo, etc., Ry Co., (1907) 205 U. S. 1, 51 L. Ed. 681, 27 S. C. R. 407; Employers' Liability Cases, (1908) 207 U. S. 463. 52 I. Fd. 297. 28 S. C. R. 141 : Southern Ry. Co. v. United States, (1911) 222 U. S. 20, 56 L. Ed. 72.32 S. C. R. 2 ; Second Employers' Liability Cases, (1912) 223 U. S. 1. 56 L. Ed. 327, 32 S. C. R. 169. 38 L. R. A. (N.S.) 44 ; Wilson v. New. (1917) 243 U. S. 332. 61 L. F.d. 755, 37 S. C. R. 298.

55 March 4, 1907, 34 Stat, at L. 1415. 
man for a period longer than sixteen consecutive hours and requiring definite rest periods in every twenty-four hours. The hours of train dispatchers and telegraphers were still further reduced, thirteen consecutive hours being the maximum where only day work was required and nine hours out of twenty-four where both night and day work was expected.

It is important to bear in mind that such a limitation upon hours of service as that provided for in the act of 1907 stands in sharp contrast, both in purpose and in constitutional justification, to such a statute as the Adamson Law providing for a standard eight-hour day on interstate railroads. While the employees affected by the Hours of Service Act would of course benefit by the relief granted from continuous labor for long hours, such relief constituted only a secondary motive for the passage of the act; certainly the legal authorization of a sixteen-hour day does not indicate a very vigorously humanitarian interest in the welfare of the workingmen affected. The object of the act was quite clearly to promote the safety of interstate commerce on railroads; and the title of the statute specifically declares it to be "An Act to Promote the Safety of Employees and Travellers upon Railroads by Limiting the Hours of Service of Employees Thereon." Viewed thus as a safety regulation, there could be no serious question as to the validity of the act; and in upholding it as a valid exercise of the power of Congress to regulate commerce Mr. Justice Hughes declared: "In its power suitably to provide for the safety of employees and travelers, Congress was not limited to the enactment of laws relating to mechanical appliances, but it was also competent to consider, and to endeavor to reduce, the dangers incident to the strain of excessive hours of duty on the part of engineers, conductors, train dispatchers, telegraphers, and other persons embraced within the clause defined by the act." ${ }^{{ }^{6} 6}$ At a later point in this article ${ }^{57}$ it will be made clear that no such argument as this was applied to the Adamson Law, and it was sustained by the Supreme Court on widely different grounds.

(b) Employers' Liability Statutes: When Congress, after considerable prodding by an energetic and persistent president, ${ }^{58}$

${ }^{56}$ Baltimore \& Ohio R. Co. v. Int. Com. Comm., (1911) 221 U. S. 612, 55 L. Ed. 878, 31 S. C. R. 621.

57 Infra, p. 315.

58 President Roosevelt urged the passage of the act in various messages to Congress. 
finally passed the first Employers' Liability Act in 1906, ${ }^{59}$ there is every reason to believe that the members of that body were actuated by a humanitarian interest in the welfare of the workmen on interstate railroads. Like the state legislatures which had passed similar laws, they wished to take away the unjust and oppressive burdens which the common law doctrines of employers' liability had placed upon the shoulders of the injured workman. Senator Dolliver, who was a particularly vigorous proponent of the law, expressed in the senate his belief that there was not a single senator "who does not recognize the equity and justice involved" in such legislation, and added that "there is scarcely an American state in these recent years which has not taken this step forward in industrial justice." ${ }^{60}$ The federal employers' liability laws were passed in order to guarantee to the men to whom they applied a reasonably square deal.

It must, therefore, have been something of a surprise to the members of Congress who had fought and voted for this legislation to learn from the Supreme Court that what they had really passed was not an act to secure economic justice in certain relations between employers and employees in interstate commerce, but a safety regulation. ${ }^{61}$ It will throw some light upon the nature of the limitations resting upon the police power of Congress to understand why it is that from the standpoint of constitutional law there is no substantial difference between the Employers' Liability Act and the Boiler Inspection Act.

It is not difficult to follow the steps in the chain of reasoning which led the Supreme Court to this somewhat startling result. In the first place, the power undèr which Congress is purporting to act in passing the Employers' Liability Act is the authority to regulate commerce; Congress has no power to regulate labor as such. It follows, therefore, that only those regulations of the relations between master and servant which are at the same time

59 June 11, 1906. 34 Stat. at L. 232.

${ }^{60}$ Quoted by Thornton in his excellent summary of the legislative history of the act. See Thornton. Federal Employers' Liability Act, 3rd ed.

61 The first Employers' Liability Act was declared unconstitutional by the Supreme Court in the Employers' Liability Cases, (1908) 207 U. S. 463, 52 L. Ed. 297, 28 S. C. R. 141, because its provisions extended to include the employees of interstate carriers even when such employees were not themselves engaged in any of the processes of interstate commerce. Congress remedied this defect in passing the second statute, April 22. 1908, 35 Stat. at L. 65. which was held valid in the Second Employers' Liability Cases, (1912) 223 U. S. 1,56 L. Ed. 327, 32 S. C. R. 169, 38 L. R. A. (N.S.) 44. 
regulations of commere within the power of Congress. Only three years before, the "court, speaking through Mr. Justice Harlan in the Adair case, had declared that one of the reasons why Congress had exceeded its power when it forbade interstate carriers to discharge any employee because he belonged to a labor union was because "there is no such connection between interstate commerce and membership in a labor organization as to authorize Congress" to pass such a law. ${ }^{62}$ Now if the only object and result of the employers' liability statutes was to secure a more equitable incidence of the burden of industrial accidents between the employers and the employees in interstate commerce and thereby to protect the welfare of a certain economic group, then Congress in passing such an act had again exceeded its authority, since it could hardly be shown that the statute really regulated interstate commerce or bore any reasonable relation to it. But if, on the other hand, it could be shown that the act would promote or protect interstate commerce in some definite way, then, of course, it could be upheld. Counsel for the government therefore wisely urged upon the court with great vigor the view that "if the conditions under which the agents or instrumentalities do the work of commerce are wrong or disadvantageous, those bad conditions may and often will prevent or interrupt the act of commerce or make it less expeditious, less reliable, less economical, and less secure." ${ }^{33}$ It is a well established principle of constitutional construction that a statute, when possible, should be so construed as to save it; and the court readily adopted the alluring argument which made it possible to sustain the validity of the act. It declared its belief that "the natural tendency of the changes described is to impel the carriers to avoid or prevent the negligent acts and omissions which are made the bases of the rights of recovery which the statute creates and defines; and as whatever makes for that end tends to promote the safety of the employees and to advance the commerce in which they are engaged, we entertain no doubt that in making those changes Congress acted within the limits of the discretion confided to it by the Constitution." ${ }^{64}$ Thus a statute which, viewed merely as a measure to insure economic justice to the employees of interstate carriers,

62 Note 25, supra.

6. Second Fmployers' Liability Cases, note 61. supra, 223 U. S. at p. 48.

${ }^{64}$ Ibid., p. 50. For a criticism of this point of view, see L. I. Hall. The Federal Employers' Liability Act. (1910) 20 Yale Law Jour. 122, in which 
would doubtless have been invalidated, was enabled to pass the scrutiny of the courts by donning the somewhat transparent disguise of a regulation to prevent railroad accidents.

3. Regulations Necessary to Prevent the Obstruction or Suspension of Interstate Commerce. It has been suggested above that perhaps the most important cause for the formation and adoption of our federal constitution was the desire to establish a government with power to regulate foreign and interstate commerce according to a uniform rule and thereby to put an end to the chaos of obstructions, burdens, and inharmonious systems of control affecting that commerce which emanated from the jealousies of thirteen separate commonwealths. The very first case in which the commerce clause of the new constitution came before the Supreme Court for interpretation was a case in which the court refused to allow the state of New York to obstruct the freedom of interstate commerce by granting to one of its citizens an exclusive right to navigate the Hudson River by steamboat. ${ }^{65}$ Since that time no small proportion of the judicial attention which the commerce clause has received has been directed to the problem of preventing state interference with interstate commerce. It would seem, therefore, that in exercising its delegated power to regulate commerce Congress could tread on no safer ground, could use its authority in no way more clearly in harmony with the purpose for which it was conferred, than when it passed regulations designed to prevent the obstruction or suspension of commerce.

And while, curiously enough, the positive enactments of this kind to be found in the federal statute books are not quite so numerous nor elaborate as one might expect, yet they present some problems of peculiar interest to those interested in the development of a national police power. They may be conveniently arranged in the following groups, each of which merits some comment.

(a) Regulations to Prevent Physical Obstructions: It is un-

it is urged that "it is only by an indirect and unsatisfactory method of reasoning that it can be said that safety in transportation is promoted by increasing the amount of damages which a railroad company must pay for the acts of carelessness of its men in their relations to each other." It will be noted that the article was written before the Second Employers' Liability Cases, were decided, but its reasoning is applicable to the doctrine of those cases.

65 Gibbons v. Ogden, (1824) 9 Wheat. (U.S.) 1, 6 L. Ed. 23. 
necessary to enlarge upon the fact that Congress has full authority to penalize any act which results in the physical obstruction or interference with commerce. "Any offense," declared Mr. Justice Story in 1838, "which thus interferes with, obstructs, or prevents such commerce and navigation, though done on land, may be punished by Congress, under its general authority to make all laws necessary and proper to execute their delegated constitutional powers." 66 Congress has accordingly enacted a fairly substantial penal code designed to preserve and protect navigable rivers and harbors from obstruction, to regulate the erection of bridges and piers, and in various other ways to keep commerce by water free and untrammeled. ${ }^{67}$ There would seem to be no doubt as to the existence of similar congressional authority to afford this kind of protection to the facilities of interstate land commerce; but, with the exception of the Larceny Act of 1913, already mentioned above, ${ }^{68}$ and some of the recent war legislation, ${ }^{69}$ Congress has, except in emergencies which will be alluded to later ${ }^{70}$ preferred to rely upon the criminal laws of the several states to prevent the physical obstruction of interstate commerce by land.

(b) Regulations to Prevent Economic Obstructions or Restraints of Commerce. (1) By combinations of capital: It would not be relevant to the subject under consideration to launch out upon any extended discussion of the highly interesting and important laws Congress has passed for the purpose of solving the socalled trust problem. The fact that the policy of the federal government toward trusts and monopolies has not always been happy in its conception or successful in its administration has little to do with the fact that the general underlying motives of that policy have always been the same: namely, to keep interstate commerce free from the obstacles and interferences resulting from monopoly and other combinations and conspiracies designed to destroy free competition and restrain trade. It will hardly be

66 United States v. Coombs, (1838) 12 Pet. (U.S.) 72, 9 L. Ed. 1004.

${ }^{67}$ See U. S. Comp. Stat. 1918 Sec. 9909 et seq.

68 Supra, p. 304, note 49.

69 The War Materials Destruction Act of April 20, 1918. By the provisions of this act the instrumentalities and facilities of interstate commerce. or "war utilities" as they are called, are, along with "war materials" and "war premises," protected from wilful injury and destruction. The act rests, of course, upon the war power of Congress and not on the commerce power.

${ }^{70}$ Infra, pp. 314,315 , notes $87,88$. 
denied that these acts are police regulations designed for the protection of commerce. The first of these statutes penalized certain specific acts, such as discriminations among shippers and rebating, which Congress deemed destructive to the freedom of competition desirable in interstate commerce. This type of regulation includes the Interstate Commerce Act of 1887 and the various amendments to it passed since that time. ${ }^{72}$ Federal police regulations making certain acts criminal were soon found to be a very inadequate means of freeing interstate commerce from monopolistic obstructions; and so Congress, convinced that relief could be had by breaking up trusts, combinations, and conspiracies in restraint of trade, enacted the famous Sherman Act of $1890 .^{72}$ After two decades of sporadic and more or less ineffectual "trust-busting," Congress supplemented the Sherman Act by legislation designed to make the act more definite in meaning and effective in operation. ${ }^{73}$ This supplementary anti-trust act, known as the Clayton Act, was accompanied by the passage of the Trade Commission Act. ${ }^{74}$ By the passage of this latter act Congress embarked upon a new policy in respect to combinations of capital-the policy of administrative control. While this act must still be regarded as a federal police regulation for the protection of commerce, the method employed for that purpose was the creation of an administrative commission with power to investigate, advise, and issue

71 Act of February 4, 1887, 24 Stat. at L. 379. The text of this act and the amendments thereto are set forth and discussed at length in Judson. Interstate Commerce, 3rd ed. See also, Fuller, The Interstate Commerce Act, (1915). One striking instance of this type of police regulation over interstate commerce is to be found in the commodities clause of the Hepburn Act, June 29, 1906, 34 Stat. at L. 584. The purpose of this act was to compel the interstate railroads to dispose of such interests as they might have in the coal mining business by making it unlawful for them to carry in interstate commerce "any article or commodity other than timber and the manufactured products thereof, manufactured, mined or produced by it, or under its authority, or which it may own in whole or in part, or in which it may have an interest, direct or indirect . . ." The legislative purpose, however, was not effectuated, because the Supreme Court in passing upon the constitutionality of the law construed it in such a way as to permit the railroad to transport coal from its own mines provided such coal had been sold by the railroad before such transportation took place." United States v. Delaware, etc., Co., (1909) 213 U. S. 366, 53 L. Ed. 836, 29 S. C. R. 527. For an excellent discussion of the history, interpretation, and operation of the clause, see Kibler, The Commodities Clause (1916): also Hand, the Commodities Clause and the Fifth Amendment, (1909) 22 Harv. Law Rev. 250.

72 Act of July 2, 1890, 26 Stat, at L. 209.

73 The Clayton Act of October 15, 1914, 38 Stat. at L. 731.

74 Act of September 26, 1914, 38 Stat. at L. 719. 
orders based upon definite findings of fact. Combinations of capital formerly in bad odor merely because of their size and importance were to be kept within the law and prevented from interfering with the freedom of commerce by an active governmental supervision and co-operation.

While the litigation which has arisen under these acts, or at least under the earlier ones, has been exceedingly voluminous and the courts have spent much time construing and applying them to the concrete problems which have arisen, there seems never to have been any serious question raised as to the authority of Congress to pass laws designed to accomplish the results which these acts sought to achieve. Such constitutional objections as have been urged against these enactments have been aimed at the details of method and procedure rather than at the validity of the legislative object. ${ }^{75}$

(2) By combinations of labor: While Congress seems never to have passed, under its commerce power, any police legislation which in express terms names labor organizations and forbids them to enter into conspiracies or to commit acts which would obstruct or suspend interstate commerce, several of its enactments are couched in terms broad enough to permit the courts to apply their restraints and prohibitions to combinations of laborers.

This is true, in the first place, of the Interstate Commerce Act of $1887 .{ }^{76}$ This act makes it unlawful for any common carrier subject to the provisions of the statute "to make or give any undue or unreasonable preference or advantage to any particular person, company, firm, corporation, or locality, or any particular description of traffic, in any respect whatsoever, or to subject any particular person, company, firm. corporation, or locality, or any particular description of traffic, to any undue or unreasonable prejudice or disadvantage." 77 It is specifically made criminal under heavy penalty for "any common carrier subject to the provisions of this act, or, when such common carrier is a corporation, any director or officer thereof, or any receiver, trustee, or lessee, agent, or person acting for or employed by such corporation," to

75 Any doubt as to the validity of the Sherman Act was set at rest by the decision in Addyston Pipe and Steel Co. v. United States. (1899) 175 U. S. 211, 44 L. Ed. 136, 20 S. C. R. 96.

${ }^{i 6}$ Note 71 , supra.

77 Sec. 3. 
do or conspire to do any of the unlawful acts above set forth. ${ }^{\text {is }}$ In 1893 Judge Taft held that these provisions were applicable to the officers and members of a brotherhood of locomotive engineers who had induced the railroad for which they worked to join them in a boycott against a railroad which was engaged in a strike because of its refusal to meet certain demands of its men. ${ }^{79}$ As long as the men remained in the employ of the railroad they were subject to injunctions to restrain them from violations of these provisions. Judge Taft also declared that a conspiracy on the part of the employees to violate these sections could be punished under the general provision of the Criminal Code penalizing those who "conspire to commit any offense against the United States." ${ }^{80}$ It is thus clear that the Interstate Commerce Act is not only applicable to common carriers but imposes restraints and obligations for the protection of interstate commerce upon labor organizations as well. ${ }^{81}$

In like manner the Sherman $\mathrm{Act}^{82}$ has been applied to acts of combinations of laborers when the effect of those acts was to interfere with interstate commerce or to restrain trade. It is unnecessary to enter here into a discussion of the question whether or not Congress actually intended to include the activities of labor organizations within the prohibitions of the act. ${ }^{83}$ It is less important that Mr. Gompers and other labor leaders believed that Congress intended that labor unions should be outside the scope of the act than it is that the Supreme Court should have found the words of the statute so broad and inclusive that it could discover no legal basis for exempting labor unions from the operation of the act. The law declares in sweeping terms that "Every contract, or combination in the form of a trust, or otherwise in restraint of trade or commerce among the several states or with foreign nations, is hereby declared to be illegal." In

78 Sec. 10. Italics are the author's.

79 Toledo, etc., Ry. Co. v. Penn. Co., (1893) 54 Fed. 730; same case, ibid., p. 746.

${ }^{80}$ Rev. Stat. Sec. 5440.

${ }^{81}$ For detailed discussion of this whole point, with citation of cases, see Judson, Interstate Commerce, 3rd ed., Chap. 6 and Secs. 408-417; Martin, The Modern Law of Labor Unions, Chap. 14.

82 Note 72, supra.

${ }^{83} \mathrm{~A}$ clear statement of both sides of the question is found in Laidler, Poycotts and the Labor Struggle, 170 et seq. 
construing that act, the courts, with practical unanimity, ${ }^{84}$ have steadily refused to make any distinction between combinations of capital and combinations of labor which were in restraint of trade. In numerous cases injunctions have been issued by the United States courts against such restraints of trade, or against more direct obstructions of commerce by labor organizations $;^{85}$ while in the Danbury Hatters case the Supreme Court held squarely that the provisions of the Sherman Act were applicable to trade unions so as to permit the recovery from the members of the hatters' union of triple damages by their employers whose business had been injured by a secondary boycott. ${ }^{86}$

During the Pullman strike of 1893 a federal circuit court issued an injunction based upon the provisions of the Sherman Act, restraining Eugene V. Debs and other officers of the American Railway Union from interfering in any way with interstate commerce or the mails. ${ }^{87}$ When the case came before the Supreme Court on appeal, however, the court declined to regard the Sherman Act as the necessary source of the authority of the court to issue the injunction (although not denying that it did confer such power), but declared that the broad grant of authority to the national government to regulate interstate commerce was sufficient in itself to warrant the granting by the courts of injunctive relief against those who obstructed or restrained such

84 The only exception seems to be United States v. Patterson, (1893) 55 Fed. 605 , in which the court took the view that "restraints of trade" must be interpreted in the strict common law sense as meaning efforts to "monopolize or grasp the market."

85 United States v. Workingmen's Amalgamated Council, (1893) 54 Fed. 994, 26 L. R. A. 158; United States v. Debs, (1894) 64 Fed. 724. Other cases in Martin, op. cit., 246, 247, note 81 , supra.

86 Loewe v. Lawlor, (1908) 208 U. S. 274, 52 L. Ed. 488, 28 S. C. R., 301, 13 Arn. Cas. 815. The result reached in this case would seem to be impossible under the existing law. The Clayton Act of October 15, 1914. specifically declares that the labor of a human being is not to be regarded as a commodity or article of commerce and that "nothing contained in the anti-trust law shall be construed to forbid the existence and operation of labor, agricultural, and horticultural organizations instituted for the purpose of mutual help and not having capital stock or conducted for profit, or to forbid or restrain individual members of such organizations from lawfully carrying out the legitimate objects thereof, nor shall such organizations or members thereof be held or construed to be illegal combinations or conspiracies in restraint of trade under the anti-trust laws." While this act legalizes certain activities of labor organizations befor regarded as illegal, it does not, of course, have the effect of permitf iny direct and substantial obstructions of interstate commerce.

87 United States v. Debs, (1894) 64 Fed. 724. 
commerce $^{88}$ From this decision it would seem, therefore, to follow that specific police legislation by Congress to prevent the obstruction of interstate commerce is unnecessary to enable federal courts sitting in equity to prevent such obstruction.

To classify the Eight-Hour Law, popularly known as the Adamson Law ${ }^{89}$ which was passed by Congress in the autumn of 1916 , as a police regulation to protect interstate commerce from obstruction and interference will seem at first a curious perversion of facts. But those who will recall the legislative history of the statute and examine carefully the opinion of the Supreme Court in the case in which the constitutionality of the law was upheld will be convinced that such a classification of the act is accurate from the standpoint both of legislative intention and of constitutional law. It seems perfectly clear that Congress passed the law at the request of President Wilson for the single purpose of averting the nation-wide railroad strike which there was every reason to believe would take place if the law were not passed. It is equally apparent that the Supreme Court upheld the law on the ground that its passage was necessary to accomplish this result and avoid the threatened suspension of interstate commerce. This remarkable decision merits some little comment.

In considering the validity of the Adamson Law, which was questioned in the case of Wilson $v$. New, ${ }^{90}$ it was necessary for the court to apply the same tests which it has always applied to regulations of commerce enacted for police purposes. ${ }^{91}$ In the first place, is the act a bona fide regulation of commerce; in the second place, assuming that it is, does it deprive any person of life, liberty, or property without due process of law? The court accordingly addressed itself to the question whether Congress was really regulating interstate commerce when it established an eight-hour day for trainmen on interstate railroads. The answer of the court to this question was that the act was a regulation of interstate commerce because its passage was necessary in order to prevent the complete suspension of that commerce. It alluded to the long list of acts, many of which have already been discussed in this article, by which Congress had sought to make interstate commerce safe and efficient. It mentioned par-

88 In re Debs, (1895) 158 U. S. 564, 39 L. Ed. 1092, 15 S. C. R. 900.

89 Act of September 3, 5, 1916, 39 Stat. at L. 721.

90 (1917) 243 U. S. 332, 61 L. Ed. 755, 37 S. C. R. 298.

91 Supra, p. 297 et seq. 
ticularly the Hours of Service Act, the Safety Appliance Acts, and the Employers' Liability Act, in all of which the power to regulate commerce had been used to control various relations between employers and employees. It then pointed out "how completely the purpose intended to be accomplished by the regulations which had been adopted in the past would be rendered unavailing or their enactment inexplicable if the power was not possessed to meet a situation like the one with which this statute [the Adamson Law] dealt. What would be the value of the right to a reasonable rate if all movement in interstate commerce could be stopped as the result of a mere dispute between the parties or their failure to exert a primary right concerning a matter of interstate commerce? Again, what purpose would be subserved by all the regulations established to secure the enjoyment by the public of an efficient and reasonable service if there was no power in government to prevent all service from being destroyed . . ? And finally, to what derision would it not reduce the proposition that government had power to enforce the duty of operation if that power did not extend to doing that which was essential to prevent operation from being completely stopped . . . ?"

The question whether the statute was in violation of the due process of law clause of the Fifth Amendment was considered by the court in a portion of the opinion which need not be treated in detail here. It is sufficient to say that the abridgment of the freedom of contract which the act entailed upon employers and employees was found constitutionally permissible because both were engaged in a business charged with a public interest and therefore subject to types of congressional regulation which could not be imposed upon any business except public utilities.

It is important to notice that the opinion of Chief Justice White marks out an entirely new boundary line for the exercise by Congress of its police power over interstate commerce for the purpose of protecting that commerce from obstruction or suspension. In the earlier cases in which the court had been obliged to decide whether or not a statute purporting to regulate commerce actually did so, it was the subject matter of the regulation which was examined. If the provisions of the statute bore a reasonable and direct relationship to interstate commerce, then, in the absence of other constitutional defects, it was held a valid regulation of commerce; if not, it was held invalid. It will be recalled that 
Mr. Justice Harlan in the majority opinion in the Adair case $e^{12}$ expressed the view that the provisions of the Erdman Act which made it a penal offense for an interstate carrier to discharge an employee because of his membership in a labor organization did not have a sufficiently close relationship to interstate commerce to make it a valid regulation thereof. Various other attempts of Congress to regulate commerce have suffered the same fate. ${ }^{93}$ But in considering whether or not the Adamson Act was a bona fide regulation of commerce the court paid practically no attention to what the law was about. The mind of the court was fixed upon what would happen if the law was not passed. It was urged upon the court that the law was, in effect, a regulation of wages and as such did not fall properly within the scope of the commerce power: The court disposed of this objection by declaring that "if it be conceded that the power to enact the statute was in effect the exercise of the right to fix wages where, by reason of the dispute, there had been a failure to fix by agreement, it would simply serve to show the nature and character of the regulation essential to protect the public right and safeguard the movement of interstate commerce, not involving any denial of the authority to adopt it." In short, it is difficult to escape the conclusion that the Supreme Court regarded the Adamson Law as a regulation of interstate commerce, not because it dealt with the wages or hours of labor of railroad employees, but because its passage was demanded by an organization which was in a position to bring about a total cessation of interstate commerce if its demand was not acceded to. If this is true, then it would seem to follow that any legislation which forms the subject matter of the demands of a body of individuals possessing the power to bring interstate commerce to a standstill if those demands are not granted, must be regarded as a legitimate exercise of the power of Congress to regulate commerce, provided such legislation does not violate the due process of law clause or any other specific constitutional prohibition. This startling doctrine without doubt opens up some rather interesting possibilities in the way of broadening the scope of the national police power under the commerce clause.

The majority opinion in Wilson $v$. New is also interesting 
because it asserts unequivocally that Congress could, without exceeding its constitutional powers, enact a new type of police regulation under the commerce clause: namely, a law providing for the compulsory arbitration of disputes between interstate carriers and their employees. In fact, Chief -Justice White took the point of view that the Adamson Act was in effect the award of a tribunal before which the railroads and the brotherhoods had been compelled to arbitrate their differences. Instead of creating special machinery for such arbitration, Congress itself served as the arbitral tribunal and enacted its award into law. "We are of opinion," declared the chief justice, "that

the act which is before us was clearly within the legislative power of Congress to adopt, and that, in substance and effect, it amounted to an exercise of its authority under the circumstances disclosed to compulsorily arbitrate the dispute between the parties by establishing as to the subject matter of that dispute a legislative standard of wages operative and binding as a matter of law upon the parties, - a power none the less efficaciously exerted because exercised by direct legislative act instead of by the enactment of other and appropriate means providing for the bringing about of such result." While it was unnecessary to the decision of the case for the court to state whether or not it would regard the general scheme of compulsory arbitration applicable to interstate carriers constitutional, the dictum was couched in such language and the underlying principle of the whole case is such as to leave little room for doubt that the court would regard such a system as a legitimate exercise of the power to regulate commerce. Congress has enacted several laws aimed to provide facilities for the arbitration of labor disputes affecting interstate commerce, ${ }^{94}$ but it has never made it obligatory upon the parties to such disputes to arbitrate; these laws providing for mediation, conciliation, and voluntary arbitration are not, therefore, police regulations in the sense in which that term is used in this article, since they subject no one to restraint or compulsion. It seems clear, however, in light of the utterances of the court in Wilson $v$. Nerv, that the continuance of the voluntary system of arbitration is a matter to be settled by legislative discretion alone, and that as soon as Congress deems it expedient an effective system of

${ }^{94}$ Act of October 1, 1888, 25 Stat. at L. 501 ; Act of June 1, 1898, 30 Stat. at L. 424 ; Act of July 15, 1913, 38 Stat. at L. 738. 
compulsory arbitration could be put into force without violating any provision of the constitution.

By way of summary of the ground covered thus far, it is apparent that no insignificant amount of legislation, social and economic in character, legislation which may properly be called national police legislation, has been passed by Congress in pursuance of its authority to protect and promote interstate commerce. In order to protect the lives, limbs, and property of those who are concerned with interstate commerce as passengers, shippers, or employees, Congress has enacted a most elaborate series of provisions relating to the physical appliances and regulations necessary to insure such safety. For the same purpose Congress has regulated in various ways the conditions under which the employees engaged in interstate commerce shall do their work. And the courts have taken a rather generous view of the amount of such welfare legislation which may be justified constitutionally upon the theory that it promotes the safety, reliability, and efficiency of interstate commerce. Finally, in order to prevent the obstruction of interstate commerce, Congress has been forced to deal with the complex problem of monopolies and combinations in restraint of trade, has imposed restrictions upon the freedom of action of organized labor, and, where collective bargaining has broken down, has assumed the role of an arbiter in disputes between labor and capital. In short, congressional responsibility for the safe, free, uninterrupted flow of commerce between the states carries with it the constitutional authority to legislate upon a wide range of problems, not commonly regarded as commercial in character, which vitally affect the national safety and welfare. 



\section{THE NATIONAL POLICE POWER}

UNDER THE

\section{COMMERCE CLAUSE OF THE CONSTITUTION*}

II. Regulations Barring the Use of Interstate Comanerce As a Conduit for Injurious Commodities and - An Aid in Illicit Transactions

Althocgh Congress in its efforts to protect the national health, morals, and general welfare has been compelled to use a process of indirection and has had to do good not merely by stealth but by subterfuge, the result has been that, under its specific grants of power to regulate interstate commerce, to tax, and to maintain a postal system, Congress has succeeded in laying a compelling or restraining hand upon numerous abuses, has wrestled with a considerable variety of economic and social problems, and has, accordingly, exercised a police power that has been real and substantial. By far the greatest number of those acts of Congress, which, even though labeled interstate commerce or tax or postal regulations, are really police enactments in disguise, have been passed under the authority to regulate commerce; a group of these, those passed to protect interstate commerce from danger or obstruction, have been discussed in the previous portion of this article. There remain still to be discussed three main groups of police regulations passed under the sanction of the commerce clause: those forbidding the use of interstate commerce as a channel for transactions that menace the national health, morals, or general welfare; those passed to co-operate with the states by forbidding the use of the facilities of interstate commerce for the purpose of evading or violating state police regulations; and finally the Child-Labor Law, by which Congress sought to deny the privileges of interstate commerce to articles produced under conditions of which Congress did not approve.

* Continued from 3 Minnesota Law Review 319. 
It has been made clear that Congress has full right under its power "to regulate commerce . . . . among the several states" to protect that commerce from danger and obstruction; and the Supreme Court has found it possible to uphold the Employers' Liability Act as necessary to protect commerce from railway accidents, and the Adamson Eight-Hour Law as necessary to keep commerce from being obstructed. But if Congress were limited in its power over interstate commerce merely to the protection of that commerce, then a good many abuses and dangers arising from or augmented by interstate commerce would be left unremedied. But Congress has not felt itself so circumscribed. It has regarded as a proper use of its authority over commerce not only the protection of commerce itself but also the protection of the public from the misuse of that commerce. One of the most interesting and important steps in the development of a national police power under the commerce clause has been the enactment of a group of laws by which the channels of interstate commerce have been closed to commodities or transactions which are injurious, not to that commerce or to any of the agencies or facilities thereof, but to the health, morals, safety, and general welfare of the nation. When Congress punishes the man who ships across a state line bottles of colored water declared by their labels to be a cure for cancer, it does so not because those bottles are a whit more dangerous to commerce than would be a consignment of shoes, but because it desires to prevent the facilities of commerce from being used as a means of distributing goods which are a fraud upon the people who buy and use them. When Congress makes it a felony to transport a woman from one state to another for immoral purposes, it does so not because it is more dangerous or injurious to an interstate carrier to carry a prostitute than to carry a clergyman, but because it is undesirable to have interstate carriers used as tools or agencies by those engaged in the white slave traffic.

There ought to be no difficulty in concluding that the authority to pass such laws is reasonably implied from the plenary power of Congress to regulate commerce. When a man is given charge of a gun or an axe he is expected not merely to keep it in repair and protect it from damage: he is expected also to see that it is not placed at the disposal of those who desire to use it in committing murder or in destroying other people's property. Whatever controversy may arise as to the power of Congress to pro- 
hibit or restrict under certain circumstances the shipment in interstate commerce of commodities which are legitimate and wholesome and are destined for legitimate and wholesome uses, there ought to be no serious doubt about the congressional authority to keep "the arteries of interstate commerce from being employed as conduits for articles hurtful to the public health, safety, or morals."

The police regulations thus enacted by Congress to prevent the use of commerce for improper purposes may be grouped under three heads: first, those designed to protect the public morals; second, those aimed to protect the public health; third, those intended to protect the public from deception and fraud. Each of these groups may be considered briefly.

1. Acts Under the Commerce Clause Protecting Public Morals. (a) Exclusion of Lottery Tickets: It would be difficult to point to any problem about which the moral judgment of the American people has changed so radically and in so short a time as it has in respect to lotteries. During the first few decades of our history lotteries were looked upon as perfectly proper forms of private enterprise, and even as useful fiscal agencies for augmenting the revenue of the state and nation. ${ }^{2}$ At the present time lotteries are thoroughly and almost universally discredited; and rigorous provisions prohibiting them are to be found on the statute books and even in the constitutions of a great majority of the states. ${ }^{3}$ In 1895 Congress lent its aid to the cause of the suppression of lotteries by passing an act which prohibited the introduction or the carriage of lottery tickets in the United States mails or in interstate commerce. ${ }^{4}$ This interesting statute was apparently passed with two purposes in view. One purpose was the desire to strike a blow indirectly, through the power of Congress over interstate commerce and the mails, at an evil over which the constitution of the United States gave Congress no direct authority. A second purpose was to prevent the anti-

1 This apt phrase is borrowed from the brilliant article by Senator Knox on Development of the Federal Power to Regulate Commerce. See 17 Yale Law Jour. 135 (1908).

2 An elaborate account of this is to be found in an article by A. R. Spofford, Lotteries in American History. Annual Rep. of Amer. Hist. Assoc., 1892 .

3 An exhaustive analysis of these state provisions and the cases construing them is to be found in Horner v. United States, (1893) 147 U: S. 449, 13 S. C. R. 409, 37 L. Ed. 237. At present probably every American state forbids them. 17 R. C. L. 1212.

4 March 2, 1895, 28 Stat. at L. 963. This now forms Sec. 237 of the criminal code of the United States, March 9, 1909, 35 Stat. at L. 1136. 
lottery statutes of the various states from being rendered ineffective by permitting the introduction of lottery tickets into the states through interstate commerce and the mails, channels beyond the reach of the police power of any state legislature.

It was not until 1903 that the Supreme Court of the United States passed upon the constitutionality of the Lottery Act. ${ }^{5}$ So important and difficult did the court regard the problems involved that it had the case argued three times before rendering its final decision, and then decided it by a vote of five to four. Some of the most distinguished members of the American bar appeared on the brief attacking the statute. Two distinct questions were raised in this case : first, are lottery tickets commodities or articles of commerce within the meaning of the constitution; second, granted that they are, does the power which Congress possesses to "regulate" commerce include the power to prohibit commerce in such commodities?

The court answered both these questions in the affirmative. It decided, first, that lottery tickets are articles of commerce; and, second, that their exclusion from interstate commerce is a proper exercise of the power to regulate that commerce. While it is unnecessary to the present discussion to comment upon the first of these questions, it will be interesting to examine briefiy the reasons which led the majority of the court to this second conclusion. "In the first place," declared the court, speaking through Mr. Justice Harlan, "in determining whether regulation may not under some circumstances properly take the form or have the effect of prohibition, the nature of the interstate traffic which it was sought by the act of March 2, 1895, to suppress, cannot be overlooked." Then follow the views of the court upon the menace of lotteries. Quoting from one of its previois decisions, ${ }^{3}$ it. asserted that "Experience has shown that the common forms of gambling are comparatively innocuous when placed in contrast with the widespread pestilence of lotteries. The former are confined to a few persons and places, but the latter infests the whole community; it enters every dwelling; it reaches every class; it preys upon the hard earnings of the poor; it plunders

5 The Lottery Case (Champion v. Ames), (1903) 188 U. S. 321, 23 S. C. R. 321. 47 L. Ed. 492 . This case involved only the validity of the exclusion of lottery tickets from interstate commerce: their exclusion from the mails had been sustained in earlier decisions. See infra pp. 386-387 and note 7 .

6 Phalen v. Virginia, (1849) 8 How. (U. S.) 163, 168, 12 L. Ed. 1030. 
the ignorant and simple." The second step in the court's argument is that Congress by virtue of its plenary power to regulate commerce among the states may "provide that such commerce shall not be polluted by the carrying of lottery tickets" unless some constitutional restriction can be found to stand in the way. "What clause," inquires Mr. Justice Harlan, "can be cited which, in any degree, countenances the suggestion that one may, of right, carry or cause to be carried from one state to another that which will harm the public morals?" The only possible clause of the constitution which might be so invoked is that which forbids the deprivation of any person's liberty without due process of law. "But surely it will not be said to be a part of anyone"s liberty, as recognized by the supreme law of the land, that he shall be allowed to introduce into commerce among the states an element that will be confessedly injurious to the public morals.

It is a kind of traffic which no one can be entitled to pursue as of right." In the third place, the court disposes of the contention that the Lottery Act, by establishing regulations of the internal affairs of the several states, violated the Tenth Amendment, which reserves to the states or to the people all powers not delegated to the United States. The court held, to begin with, that this contention overlooks the fact that the Lottery Act is a regulation of commerce and that the power to regulate commerce is specifically given to Congress by the constitution. But, aside from that, the act does not purport to suppress the traffic in lottery tickets which is carried on entirely within the limits of a state, but only that traffic which is interstate. Furthermore, instead of invading the proper field of police regulation and usurping the powers of control over the morals of the people of the state-

"Congress only supplemented the action of those statesperhaps all of them-which, for the protection of the public morals, prohibit the drawing of lotteries, as well as the sale or circulation of lottery tickets, within their respective limits. It said, in effect, that it would not permit the declared policy of the states, which sought to protect their people against the mischiefs of the lottery business, to be overthrown or disregarded by the agency of interstate commerce. We should hesitate long before adjudging that an evil of such appalling character, carried on through interstate commerce, cannot be met and crushed by the only power competent to that end. We say competent to that end, because Congress alone has the power to occupy, by legislation, the whole field of interstate commerce." 
After noticing as precedents or analogies some of the other instances in which congressional regulations of commerce have taken the form of prohibition,- - namely, the prohibition of the interstate transportation of diseased cattle, the prohibitions comprising the Sherman Anti-Trust Act, and the prohibition resulting from the operation of the Wilson Act of 1890, which subjected to state police control interstate shipments of liquor upon their arrival within the state- the court takes particular pains to make clear the limited scope of this important decision. This case does not at all establish the right of Congress to "exclude from commerce among the states any article, commodity, or thing, of whatever kind or nature, or however useful or valuable, which it may choose, no matter with what motive. . . ." The court will consider such arbitrary exclusions from interstate commerce only when it is necessary to do so. "The whole subject is too important, and the questions suggested by its consideration are too difficult of solution to justify any attempt to lay down a rule for determining in advance the validity of every statute that may be enacted under the conmerce clause. We decide nothing more in the present case than that lottery tickets are subjects of traffic among those who choose to sell or buy them: that the carriage of such tickets by independent carriers from one state to another is therefore interstate commerce: that under its power to regulate commerce among the several states Congresssubject to the limitations imposed by the constitution upon the exercise of the powers granted-has plenary authority over such commerce, and may prohibit the carriage of such tickets from state to state; and that legislation to that end, and of that character, is not inconsistent with any limitation or restriction imposed upon the exercise of the powers granted to Congress."

The Lottery Case was decided by a divided court with four justices dịssenting. The dissenting opinion, written by Chief Justice Fuller, was based on the conviction of the minority that lottery tickets were not articles of commerce and that, even if they were, the power to regulate interstate commerce does not carry with it the absolute power to prohibit the transportation of articles of commerce. It was pointed out that when the court held that exclusion of lottery tickets from the mails was a proper exercise of the power of Congress over the postal system it had been expressly said that Congress did not have the power to exclude from transportation in interstate commerce articles which 
it might properly exclude from the mails. ${ }^{\top}$ This dissent is also interesting because it specifically states that Congress does not have as extensive power over interstate commerce as it does over foreign and Indian commerce. "There is no reservation of police power or any other to a foreign nation or to an Indian tribe, and the scope of the power is not the same as that over interstate commerce." Consequently the instances in which Congress has excluded various articles from importation or from traffic with the Indian tribes do not serve as precedents for similar restrictions upon interstate commerce. ${ }^{8}$

The decision in the Lottery Case has been discussed at leingth because it was in a sense a pioneer decision, because it has had a profound influence upon the subsequent development of the national police power, and because, in spite of Mr. Justice Harlan's warning against making unwarranted deductions from it, it has been regarded by many as establishing a doctrine regarding the power of Congress to prohibit various kinds of interstate commerce which is far more revolutionary than it was the expressed purpose of the court to sanction. It is quite as important to keep clearly in mind the things which the Lottery Case does not hold as it is to remember the things which it does. In the first place, it does not hold that Congress has the same power to exclude articles from interstate commerce that it has to exclude them from importation in foreign commerce. It already has been suggested that this view was urged upon the court by counsel for the government, but that the decision carefully avoided any expression of opinion regarding it. ${ }^{9}$ In the second place, it does not hold that Congress may exclude anything from interstate commerce except those commodities the distribution of which menaces the public health, morals, or safety. Finally, it does not hold that Congress has the power to exclude harmless and legitimate commodities or transactions from interstate commerce merely because such exclusions would result in a needed or desirable protection to the public health, safety, or morals. It does not, therefore, establish a precedent for the recently invalidated Child-Labor Law. It merely upholds the exclusion of such com-

7 In re Rapier, (1892) 143 U. S. 110, 12 S. C. R. 374, 36 L. Ed. $93 . \quad$ Ex parte Jackson, (1877) 96 U. S. 727, 24 L. Ed. 877.

8 The Lottery Case is severely criticized in an article by W. A. Sutherland, Is Congress a Conservator of the Public Morals? (1904) 38 Amer. Law Rev. 194.

9 See first section of this article, 3 Minnesota Law Review 301. 
modities as are themselves by their nature and effects a menace to the public welfare.

(b) Exclusion of Obscene Matter: The use of the power of Congress to regulate commerce for the purpose of suppressing the circulation of obscene literature or pictures dates back to the year $18+2 .{ }^{10}$ However, this early statute merely forbade the importation of obscene matter into this country from abroad. As time went on the scope of this legislation was expanded to include within its prohibitions not only obscene literature and prints but also contraceptive devices, drugs, and information. ${ }^{11}$ But it was not until 1897 that Congress finally penalized the distribution of such literature and articles through the channels of interstate commerce. ${ }^{12}$ With some slight modifications, this statute forms a part of the present criminal code of the United States. ${ }^{13}$ The act contains the two fairly distinct types of prohibition already in the earlier statutes. In the first place, it makes it a crime to deposit with any common carrier for the purpose of interstate transportation any obscene literature, pictures, images, or articles. In the second place, it excludes from interstate commerce in the same way all articles or drugs designed to prevent conception or to produce illegal abortions and all literature or advertisements containing contraceptive information or telling where the articles or information may be secured.

It is quite clear that the purpose of this legislation was to protect the public morals and not to protect interstate commerce. Certainly that commerce is in no greater danger of destruction, loss, or interference from the transportation of obscene literature than it is from the transportation of Bibles. In passing these laws Congress aimed to prevent interstate commerce from being used as a medium for distributing articles or printed matter which it regarded as morally degrading.

IV hile the Supreme Court of the Lnited States has never passed squarely upon the constitutionality of this legislation, it has cited with approval the decision of a lower federal court which held it valid, ${ }^{14}$ so that the constitutional soundness of such

10 Act of August 30, 1842, 5 Stat. at L. 562, Sec. 28.

11 Act of March 2, 1857, 11 Stat. at L. 168; March 3, 1873, 17 Stat. at L. 598: March 3, 1883, 22 Stat. at L. 489: October 3, 1913, 38 Stat. at L. 194.

12 Act of February 8, 1897, 29 Stat. at L. 512.

13 Narch 4, 1909: 35 Stat. at L. 1138. Sec. 245. 523

${ }^{14}$ Hoke v. United States, (1913) 227 C. S. 308, 33 S. C. R. 281, 57 L. Ed. 
use of the commerce power may be said to have passed into the realm of settled law. That part of the statute which forbids the transmission through interstate commerce of contraceptive articles or information was the first to be subjected to judicial scrutiny, and its validity was sustained by the United States district court in the case of United States $v$. Popper. ${ }^{15}$ The statute was attacked primarily upon the ground that Congress was without constitutional authority to pass it, since it dealt with the internal affairs of the states and invaded, therefore, the field of legislative authority reserved to the states by the Tenth Amendment. The court disposed of the contention with a confident directness and brevity of argument that is in striking contrast to the labored treatment which the principle involved usually received in other cases. The power to regulate commerce "includes power to declare what property or things may be the subjects of commerce." The power of Congress to prohibit commerce in certain commodities with the Indian tribes has long been recognized. ${ }^{16}$ In the Liccnse Cases Chief Justice Taney asserted that the power of Congress to regulate the commerce with foreign nations conferred the authority to "prescribe what articles of merchandise shall be admitted and what excluded," and also declared that the power to regulate interstate commerce was equal in scope to the power to regulate foreign commerce. ${ }^{17}$ It follows, therefore, that under its power over interstate commerce Congress has the power to prohibit the transportation of articles designed for immoral use.

It is interesting to notice that, while the result reached in the Popper case has been regarded as correct, the theory upon which the court relied in reaching that result has been tacitly if not openly discredited. That theory is that Congress may exclude things from interstate commerce because it niay exclude them from foreign and Indian commerce; and it has already been made clear $^{18}$ not only that the Supreme Court in deciding the Lottery Case refused to make any use of the argument that the power of Congress over foreign and interstate commerce is the same, but also that a growing body of legal opinion has been won over to the view that the two powers are quite different in scope. No

15 (1899) 98 Fed. 423. 182.

16 Citing United States v. Holliday, (1866) 3 Wall. (U. S.) 407, 18 L. Ed.

17 (1847) 5 How. (U. S.) 577, 12 L. Ed. 256.

1 Supra, p. 387. 
other case has been found in which the reasoning of the court in this case has been followed.

That portion of the act of 1897 relating to the exclusion of obscene literature from interstate commerce was held constitutional in a case in the United. States circuit court of appeals in 1914. ${ }^{19}$ The opinion in this case does not call for extended comment. The contention that congressional authority does not extend to the prohibition of commodities from interstate commerce was met by the citation of the cases in which the Supreme Court had upheld the power of Congress to prohibit the interstate transportation of lottery tickets, diseased cattle, and women for immoral purposes. The argument that the statute violated the First Amendment by abridging the freedom of the press was disposed of with the succinct remark that "we think that the freedom of the press has enough to answer for without making it a protecting shield for the commission of crime."

(c) The White Slav'e Act: In 1910 Congress enacted the famous Mann Act, which bore the title, "An Act Further to Regulate Interstate and Foreign Commerce by Prohibiting the Transportation Therein for Immoral Purposes of Women and Girls, and for Other Purposes."20 Here again Congress was not protecting interstate commerce from any dangers, direct or indirect, which menaced that commerce; the safety and efficiency of interstate commerce is not dependent upon the private morality of the passengers on interstate trains. The purpose of the statute was to strike a blow at the white slave traffic by refusing to allow interstate commerce to be used any longer as a means of assisting those who promote the nefarious system of commercialized vice.

The Mann Act was held constitutional by the Supreme Court in 1913 in the case of Hoke $v$. United States. ${ }^{21}$ The statute was attacked on the ground that it violated the privileges and immunities of citizens of the United States by denying free right of passage in interstate commerce; that it was a perversion of the power of Congress to regulate interstate commerce by exceeding unduly the proper scope of that power; and on the ground that it contravened the Tenth Amendment by invading the legitimate domain of the police power of the states in an attempt to regulate the private morals of the people.

19 Clark v. United States, (1914) 211 Fed. 916.

20 June 25, 1910. 36 Stat. at L. 825.

21227 . U. S. 308, 35 S. C. R. 281, 57 L. Ed. 523. 
In answer to the first objection, the court denied that any person enjoys a constitutionally protected right to use interstate commerce for the furtherance of immoral designs. "The contention confounds things important to be distinguished. It urges a right exercised in morality to sustain a right to be exercised in immorality. . . . It is misleading to say that men and women have rights. Their rights cannot fortify or sanction their wrongs; and if they employ interstate transportation as a facility of their wrongs, it may be forbidden to them to the extent of the act of June 25, 1910, and we need go no further. . . ." The court also disposed of the other contentions by declaring the act to be a proper exercise of the power to regulate commerce. This being the case its effect on the normal scope of state police power is quite irrelevant. The court alluded in rather sweeping terms to the police power which Congress may legitimately exercise through its control over commerce:

"The powers reserved to the states and those conferred on the nation are adapted to be exercised, whether independently or concurrently, to promote the general welfare, material and moral. This is the effect of the decisions; and surely if the facility of interstate transportation can be taken away from the demoralization of lotteries, the debasement of obscene literature, the contagion of diseased cattle or persons, the impurity of food and drugs, the like facility can be taken away from the systematic enticement to and the enslavement in prostitution and debauchery of women, and, more insistently, of girls.

"The principle established by the cases is the simple one, when rid of confusing and distracting considerations, that Congress has power over transportation 'among the several States': that the power is complete in itself, and that Congress, as an incident to it, $\sim$ may adopt not, only means necessary but convenient to its exercise, and the means may have the quality of police regulations."

While the opinion of Mr. Justice McKenna in the Hoke case rests upon the same principle as that upon which the Lottery Case was decided, the language used in certain portions above quoted is broad enough in its implications to sanction the doctrine that the power to regulate interstate commerce may take the form of prohibition not merely when such prohibition is necessary to prevent the distribution of commodities or the consummation of transactions in themselves definitely injurious to the public health, morals, or safety, but it may also take the form of prohibition, regardless of the character of the things exclitded, 
when such prohibition will contribute substantially to the national welfare. It is not surprising, therefore, to find Mr. Justice McKenna one of the four who dissented from the opinion of the majority in the case in which the federal Child-Labor Law was held invalid ;22 for his opinion in the Hoke case reflects the view that Congress has broad authority to use the power to regulate interstate commerce in any manner which will "promote the general welfare, material and moral."

(d) E.rclusion of Prize Fight Films: In 1912 Congress enacted a law excluding from foreign and interstate commerce and the mails all prize fight films or pictures. ${ }^{23}$ This was, of course, merely another attempt to keep the postal service and commerce from serving as distributing agencies for goods which Congress regarded as demoralizing in effect.

The only portion of this act which has thus far been attacked in the courts is that which prohibits the importation of the objectionable films from abroad. This was upheld by the United States Supreme Court in 1915 in the case of Weber $v$. Freed. ${ }^{2 *}$ In this case the court contented itself with the briefest possible conment on the argument that Congress had exceeded its delegated powers and had invaded the domain of state police legislation; comment which culminated in the statement, "But in view of the complete power of Congress over foreign commerce and its authority to prohibit the introduction of foreign articles recognized and enforced by many previous decisions of this court, the contentions are so devoid of merit as to cause them to be frivolous." While the court gave no hint of what its attitude would be toward the question of the validity of the provision of the act forbidding the shipment of prize fight films in interstate commerce, the act is so obviously identical in purpose and constitutional principle with the Lottery Act, the Obscene Literature Act, and the White Slave Act, as to leave no doubt whatever regarding its constitutionality. ${ }^{25}$ 1101

22 Hammer v. Dagenhart, (1918) 247 U. S. 251, 38 S. C. R. 529, 62 L. Ed.

23 Act of July 31, 1912.37 Stat. at L. 240.

24239 L. S. 325. 36 S. C. R. 131, 60 L. Ed. 308.

2. In two cases involving the validity of this law, Weber v. Freed, (1915) 224 Fed. 355. United States v. Johnson. (1916) 232 Fed. 970, the lower federal courts argued that Congress could exclude the films from foreign commerce because its power to exclude objectionable articles from interstate commerce had been so f requently sisstained. Such an argument leaves little room for doubt as to the views of these courts on the question of the validity of excluding the films from interstate commerce. After the efforts which have been made from time to time to prove that the power of Congress to 
2. Protection to Public Health. Congress has exercised a national police power by virtue of its authority to regulate interstate commerce nowhere more frequently and nowhere with more general public approval than in the enactment of laws designed to close the channels of commerce to impure, adulterated, or unhealthful products and to the possible breeders and carriers of disease. By far the greater portion of the rather voluminous legislation of this type which has been placed on the federal statute books has provoked neither serious discussion regarding its constitutionality nor actual litigation. And while in a few instances these laws have been squarely attacked in the courts, and decisions sustaining their constitutionality have been rendered, there have been other cases in which the court has found opportunity to give evidence of its approval of such legislation only in some collateral action. It is appropriate to the purpose of this article to consider only the more interesting and important of these laws and the cases construing them, rather than to attempt an exhaustive compilation. It seems natural to allow them to fall into two general classes: first, the acts excluding from interstate commerce impure, unwholesome, or adulterated food or drugs; and, second, the acts to prevent the spread through the channels of interstate commerce of disease, infection, or parasites.

(a) Exclusion of Impure, Unaholesome, or Adulterated Food or Drugs: The forerunners of the more recent acts excluding these objectionable commodities from interstate conmerce are the laws forbidding the importation of such commodities from abroad. This power Congress has exercised since 1848 . In that year it passed an act "to prevent the importation of spurious and adulterated drugs" and to provide a system of inspection to , make the prohibition effective. ${ }^{26}$ Such legislation guarding against the importation of unhealthfully adulterated food, drugs, or liquor has been on the statute books ever since. ${ }^{2 \pi}$ In 1887 the importation by Chinese of smoking opium was pro-

regulate interstate commerce is as broad as its power over foreign commerce, it is inter esting to see the court in the Johnson case arguing the other way and urging that "the constitutional power of Congress over commerce extends, not only to interstate, but to foreign conmerce, and what it may do with respect to the one it may do with respect to the other."

26 Act of June 26. 1848, 9 Stat. at L. 237.

27 See the following acts: March 1, 1899, 30 Stat. at L. 951 ; May 25. 1900, 31 Stat. at L. 196; March 2, 1901, 31 Stat. at L. 930 ; June 3, 1902, 32 Stat. at L. 296; March 3, 1905, 33 Stat. at L. 874; June 30, 1906, 34 Stat. at L. 684. 
hibitef, ${ }^{2 s}$ and subsequent statutes passed in $1909^{2.9}$ and $1914^{30}$ made it unlawful for any one to import it. In 1897 Congress forbade the importation of any tea "inferior in purity, quality, and fitness for consumption" as compared to a legal standard. ${ }^{31}$ The constitutionality of this provision was attacked in the courts, but the act was sustained by the Supreme Court in an opinion which has become one of the leading cases establishing the power of Congress to prohibit the importation of commodities. ${ }^{32}$

Ultimately Congress began to exclude from interstate commerce also various types of adulterated and unwholesome food and drug products. The earlier laws of this kind were not very comprehensive. In 1891 an act was passed which provided for the inspection of all live cattle destined for slaughter and intended for export or for shipment in interstate commerce, and the inspection of such cattle after slaughter, if that was considered necessary ; and cattle or carcasses found to be unsound or diseased were not allowed to be shipped in interstate or foreign commerce. $^{33}$ However, the shipment of cattle or meat which had not been inspected at all was not forbidden; a fact which put very obvious limitations upon the scope and effectiveness of the act. In 1902 a statute was passed forbidding interstate commerce in all viruses, serums, toxins, antitoxins, and the like, "applicable to the prevention of the diseases of man," except when

28 Act of February 23, 1887, 24 Stat. at L. 409.

29 Act of February 9, 1909, 35 Stat. at L. 614.

30 Act of January 17, 1914, 38 Stat. at L. 275. The Supreme Court upheld this statute in Brolan v. United States, (1915) 236 U. S. 216, 35 S. C. R. 285. 59 L. Ed. 541. The court said: "The entire absence of all ground for the assertion that there was a want of power in Congress for any reason to adopt the prorision in question is so conclusively foreclosed by previous decisions as to leave no room for doubt as to the wholly unsubstantial and frivolous character of the constitutional question based on such contention."

31 Act of March 2, 1897, 29 Stat. at L. 605 .

32 Buttfield v. Stranahan, (1904) 192 U. S. 470, 498, 24 S. C. R. 349, 356, 48 L. Ed. 525, 536. The conclusiven ${ }^{\circ}$ ss with which the court settled the case will be apparent from the following excerpt from Mr. Justice White's opinion: "Whatever difference of opinion, if any, may have existed or does exist concerning the limitations of the power [to regulate commerce], resulting from other provisions of the Constitution, so far as interstate commerce is concerned, it is not to be doubted that from the beginning Congress has exercised a plenary power in respect to the exclusion of merchandise brought from foreign countries; not alone directly by the enactment of embargo statutes, but indirectly as a necessary result of provisions contained in tariff legislation. It has also, in other than tariff legislation, exerted a police power over foreign commerce by provisions which in and of themselves amounted to the assertion of the right to exclude merchandise at discretion."

33 Act of March 3, 1891, 26 Stat. at L. 1089. 
such commerce is carried on by persons holding licenses from the Department of Agriculture, and except when the products mentioned conform to standards of purity and effectiveness established by the department. ${ }^{34}$ A similar law was passed in 1913, applicable to serums used for domestic animals. ${ }^{35}$ However, in 1906, Congress approached in earnest the problem of stopping the distribution and sale of impure food and drugs in so far as its power to regulate interstate commerce gave it authority to do so; and in that year it passed two comprehensive and far-reaching statutes known as the Pure Food $\mathrm{Act}^{36}$ and the Meat Inspection Act. ${ }^{37}$

It is unnecessary to discuss in detail the provisions of these acts. The Pure Food Act excludes from interstate commerce all adulterated and misbranded food and drugs. Its definitions of the terms "adulterated" and "misbranded" are broad enough to include practically all unwholesome food and drug products and those fraudulently compounded or labeled. It seems clear that Congress had two purposes in mind in passing the Pure Food Act; one was to "protect the health of the people by preventing the sale of normally wholesome articles to which have been added substances poisonous or detrimental to health," the other was to "protect purchasers from injurious deceits by the sale of inferior for superior articles." 38 Without attempting to decide which, if either, of these purposes was paramount in the congressional mind, it is entirely proper to regard the act as one which aims to protect the health of the nation.

After the decision in the Lottery Case, it would hardly be expected that the question of the constitutionality of the Pure Food Act would prove difficult of solution. Several of the lower federal courts disposed of the question by reference to the authority of that case, ${ }^{39}$ and in the two cases in which the validity of the act was touched upon by the Supreme Court such validity seems to. have been assumed rather than established by elaborate

34 Act of July 1, 1902, 32 Stat. at L. 728.

35 Act of March 4, 1913, 37 Stat. at L. 832.

36 Act of June 30, 1906, 34 Stat. at L. 768.

37 Act of June 30, 1906, 34 Stat. at L. 674.

38 From the opinion of the court in Hall-Baker Grain Co. v. United States, (1912) 198 Fed. 614.

39 Shawnee Milling Co. v. Temple, (1910) 179 Fed. 517 ; United States v. 420 Sacks of Flour, (1910) 180 Fed. 518; United States v. Serenty-four Cases of Grape Juice, (1910) 181 Fed. 629. For an elaborate discussion of the purpose and validity of the Act of 1906. with citation of cases, see Thornton, Pure Food and Drugs, (1912) Part II, Ch. II. 
argument. In the first of these cases, The Hipolite Egg Co. $v$. Unitcd States, ${ }^{40}$ the question arose whether the provisions of the act authorized the confiscation of adulterated food after it had reached its destination and was still in the original package. That there was no doubt in the mind of the court as to the validity of the law is evidenced by the language used in upholding the right of confiscation claimed by the government. The court said: "In other words, transportation in interstate commerce is forbidden to them [the adulterated products], and, in a sense, they are made culpable as well as their shipper. It is clearly the purpose of the statute that they shall not be stealthily put into interstate commerce and be stealthily taken out again upon arriving at their destination and be given asylum in the mass of property of the state." In the case of McDermott $v$. $W_{\text {isconsin }}{ }^{41}$ the point at issue was whether the provisions of a Wisconsin statute relative to the labeling of food products conflicted with the federal law. While the constitutionality of the Pure Food Act was not squarely attacked, the Supreme Court took occasion to express itself clearly upon that point. It said:

"That Congress has ample power in this connection is no longer open to question. That body has the right not only to pass laws which shall regulate legitimate commerce among the states and with foreign nations, but has full power to keep the channels of such commerce free from the transportation of illicit or harmful articles, to make such as are injurious to the public health outlaws of such commerce and to bar them from the facilities and privileges thereof. . . . The object of the statute is to prevent the misuse of the facilities of interstate commerce in conveying to and placing before the consumer misbranded and adulterated articles of medicine or food."

The Meat Inspection Act, as its name suggests, provides an elaborate system of government inspection of meat before and after slaughter and during the process of packing, as well as of the premises on which these processes are carried on, and forbids the shipment in interstate or foreign commerce of meat or meat products not so inspected. While applicable to a somewhat different set of conditions, it is quite clear that this statute is the same in purpose and rests upon exactly the same constitutional principles as the Pure Food Act. The validity of the act has never been questioned before the United States Supreme Court. 
(b) Exclusion to Prevent the Spread of Disease, Infection, or Parasites: Congress has imposed quarantine regulations upon foreign and interstate commerce to prevent the spread of human disease, diseases of livestock, and diseases and pests which attack plant and tree life. The more interesting and important of these acts may be briefly mentioned.

It is hardly within the scope of this article to allude to the numerous statutes whereby Congress has sought to prevent the introduction of human disease into this country through the channels of foreign commerce. ${ }^{42}$ During serious epidemics laws have sometimes been passed to prevent the spread of disease from state to state by imposing restrictions upon the freedom of passage in interstate commerce. Thus in 1890 the President was authorized by law to take such measures as might be necessary to prevent the spread of cholera, yellow fever, smallpox, and the plague. ${ }^{43}$

Much more numerous have been the statutes aimed to prevent the spread of animal diseases through the channels of commerce. By the act of 1890 the President was given power to suspend entirely for a limited time the importation of any class of animals when necessary to protect animals in this country from diseases. ${ }^{44}$ In 1884 the exportation or shipment in interstate commerce of livestock having any infectious disease was forbidden $;^{45}$ in 1903 power was conferred upon the Secretary of Agriculture to establish such regulations to prevent the spread of such diseases through foreign or interstate commerce as he might consider necessary $;^{46}$ in 1905 the same official was specifically authorized to lay an absolute embargo or quarantine upon all shipments of cattle from one state to another when the public necessity might demand it. ${ }^{47}$ While the Supreme Court has held unconstitutional such federal quarantine regulations of this sort as have been made applicable to intrastate shipments of livestock, on the ground that federal authority

42 For existing regulations see Comp. Stat. 1918, Secs. 9150-9182. See article by Edwin Maxey, Federal Quarantine Laws, (1909) 43 Amer. Law Rev. 382 .

43 Act of March 27, 1890, 26 Stat. at L. 31.

44 Act of August 30, 1890, 26 Stat. at L. 416.

45 Act of May 29, 1884, 23 Stat. at L. 31.

46 Act of February 2, 1903, 32 Stat. at L. 791.

47 Act of March 3, 1905, 33 Stat. at L. 1264. 
extends only to foreign and interstate commerce, ${ }^{48}$ the general validity of this type of regulation has been tacitly assumed. ${ }^{49}$

A statute of 1905 forbade the transportation in foreign and interstate commerce and the mails of certain varieties of moths, plant lice, and other insect pests injurious to plant crops, trees, and other vegetation. ${ }^{50}$ In 1912 a similar exclusion of diseased nursery stock was made effective, ${ }^{51}$ while by the same act, and again by an act of 1917,52 . the Secretary of Agriculture was invested with the same powers of quarantine on interstate commerce for the protection of plant life from disease as those above described for the prevention of the spread of animal disease. All of this legislation has apparently gone unattacked in the courts, but no doubt can possibly exist as to the congressional authority to enact it.

3. Protection of the Public Against Fraud. In concluding the treatment of this general type of national police regulation under the commerce clause, some instances may be mentioned in which Congress has excluded commodities from commerce in order to protect the public from fraud and deception. These statutes are included for the sake of logical completeness rather than because they contribute anything new to the constitutional principles already discussed.

There is probably no question that the act of 1902 excluding from commerce food and dairy products falsely branded as to the state in which they were made or produced ${ }^{53}$ was designed to prevent frauds upon the consumer rather than to protect him from any menace to his health. Butter made in Ohio does not become unwholesome because its label falsely states that it was made in Illinois; but the statute proceeds on the assumption that the purchaser has a right to know where it really was made.

As has already been suggested, when Congress passed the Pure Food Act of $1906^{54}$ it desired not only to protect the public health but also to protect the public from fraud, by making it possible for persons who receive food or drug products through foreign or interstate commerce to be reasonably sure of knowing

4 I11. Cent. R. Co. v. McKendree, (1906) 203 U. S. 514, 27 S. C. R. 153, 51 L. Ed. 298.

${ }^{49} \mathrm{As}$ in Reid v. Colorado, (1902) 187 U. S. 137, 23 S. C. R. 92, 47 L. Ed. 108, where the Act of May 29.1884, supra, was construed and applied.

50 Act of March 3, 1905, 33 Stat. at L. 1269.

$\therefore$ Act of August 20, 1912, 37 Stat. at L. 315.

:.2 Act of March 4, 1917, 39 Stat. at L. 1165.

83 Act of July 1, 1902, 32 Stat. at L. 632.

in Supra, note 36. 
what they were getting. To this end the statute was made to include detailed provisions regarding the adequate and honest labeling or branding of food or drugs, and adulterations and false markings were forbidden even though the products might be perfectly harmless and healthful. The provisions of the act, aimed at fraudulent brands and labels, were further strengthened by the enactment in 1912 of an important amendment which stipulated that drugs should be held to be "misbranded" if the "package or label shall bear or contain any statement, design, or device regarding the curative or therapeutic effect of such article or any of the ingredients or substances contained therein, which is false and fraudulent." ${ }^{55}$ An effective blow was thus struck at the advertising methods of the purveyors of "quack" medicines and nostrums. A still later amendment to the same act struck at a different sort of fraud by requiring that the net weight of the contents be marked on packages of food or druys. ${ }^{56}$

Various other statutes have been passed to deny the privileges of commerce to other kinds of fraudulent products. Among these may be mentioned the act excluding from commerce "falsely or spuriously stamped articles of merchandise made of gold or silver, or their alloys," 57 the act excluding adulterated or misbranded insecticides and fungicides, ${ }^{58}$ and the recent Grain Standards Act ${ }^{59}$ excluding all grain unless inspected and found to be of standard grade. None of this legislation calls for extended comment.

When one considers the wide scope of the police power which Congress has exercised by closing the channels of commerce to commodities and transactions which menace the public morals, health, and welfare, it is quite natural to let the highly important and salutary purposes which Congress has furthered by this legislation obscure the precise-and quite limitedmethods by which Congress accomplished these ends. From the fact that Congress has excluded from commerce articles which if distributed and consumed would prove dangerous to the public health, it has been an easy step to conclude that Congress might

55 Act of August 23, 1912, 37 Stat. at L. 416. This amendment was rendered necessary by the decision in United States v. Johnson, (1911) 221 U. S. 488,31 S. C. R. 627,55 L. Ed, 823 , which held that the word "misbranded" as used in the Act of 1906 did not apply to false statements as to the curative properties of drugs.

56 Act of March 3, 1913, 37 Stat. at L. 732.

57 Act of June 13, 1906. 34 Stat. at L. 260.

58 Act of April 26, 1910, 36 Stat. at L. 331.

59 Act of August 11, 19i6, 39 Stat. at L. 482. 
exclude from commerce anything, regardless of its character or intended use, if by using such exclusion as a club or penalty there might result a still more adequate protection of the public health. Whether or not it is logically possible to infer the existence of this broader national police power from the cases which have thus far been discussed-and this has proved to be a highly controversial question-there is small reason to believe that the courts by which those cases were decided expected or desired any such inferences to be drawn from them. All that it is necessary to infer from the statutes and decisions thus far reviewed is that under its power to regulate interstate commerce Congress may properly be charged with the responsibility of seeing that the commerce so committed to its care is not used as a "conduit" for the distribution of injurious products or as a facility for the consummation of injurious transactions.

\section{Regulations Barring the Use of Interstate Comanerce}

For the Evasion or Violation of State

\section{Police Regulations}

It will be noted that in the statutes discussed in the above section the articles or transactions which were barred out of interstate commerce were those which Congress itself regarded as injurious to the public welfare. A problem which has presented far greater difficulties both for Congress and the courts has been the problem of how to deal with the interstate transportation of commodities, such as intoxicating liquors, which Congress, instead of excluding from interstate commerce, has recognized as legitimate articles of that commerce, ${ }^{60}$ but which have, at the same time, been regarded by some of the states as so harmful as to warrant the complete prohibition of their production, sale, and even possession. The problem has taken the form of a dilemma. To allow the individual states at their discretion to exclude from their borders legitimate articles of commerce, or to allow them to decide for themselves what articles of commerce are legitimate and to exclude the others,

60 "By a long line of decisions, beginning even prior to Leisy v. Hardin, (1890) 135 U. S. 100 , it has been indisputably determined that beer and other intoxicating liquors are a recognized and legitimate subject of interstate commerce." Louisville \& Nashville R. Co. v. Cook Brewing Co.. (1912) 223 U. S. 70, 32 S. C. R. 189, 56 L. Ed. 355. See the exhaustive citation of cases in 12 Corpus Juris 20. 
would seem to be a reversion to the non-uniform, obstructive, and wholly unsatisfactory system of commercial regulation by the states which it was one of the primary purposes of the framers of the federal constitution to abolish forever. On the other hand, to pour intoxicating liquor through the channels of interstate commerce into a state which is struggling with the already difficult problem of making its prohibition laws effective seems to be very bad policy if not also bad law. It has taxed to the utmost the ingenuity of Congress and, it may be said, of the courts as well, to steer a middle course between the horns of this dilemma; to avoid forcing liquor down the throats of states which do not want it, without sacrificing the vital principle of uniformity in the regulation of interstate transportation of commodities. The steps in the development of this problem and the various efforts which Congress has made to solve it may properly claim some attention, inasmuch as these efforts may be regarded as exercises of a national police power under the commerce clause.

1. The Original Package Doctrine. ${ }^{61}$ That goods imported from foreign countries do not become subject to the jurisdiction of the individual states so long as they remain in the original packages in which they were shipped and have not been merged in the general mass of the property of the state was settled in $1827 .{ }^{62}$ But when twenty years later the question was presented to the Supreme Court in the License Cases $^{63}$ whether a state could prohibit or restrain by the requirement of a license the sale in the original packages of liquor brought in from other states or from abroad the court answered that it could. There was no act of Congress with which the state statutes in question could be said to conflict, and such regulation of interstate shipments of liquor could be held invalid only on the theory that the grant of power to Congress to regulate interstate commerce was exclusive and precluded any state regulation on the same subject even though Congress had not yet exercised its power over it. The leading opinion, which was written by Chief Justice Taney, definitely rejected this theory.

61 This problem is treated in detail in the first of a valuable series of articles by Lindsay Rogers on Interstate Commerce in Intoxicating Liquors Before the Webb-Kenyon Act, (1916) 4 Va. Law Rev. 174.

62 Brown v. Maryland, (1827) 12 Wheat. (U. S.) 419, 6 L. Ed. 678.

63 (1847) 5 How. (U. S.) 504, 12 L. Ed. 256. 
"The mere grant of power to the general government [declared the chief justice] cannot, upon any just principles of construction, be construed to be an absolute prohibition to the exercise of any power over the same subject by the states. The controlling and supreme power over commerce with foreign nations and the several states is undoubtedly conferred upon Congress. Yet, in my judgment, the state may, nevertheless, for the safety or convenience of trade, or for the protection of the health of its citizens, make regulations of commerce for its own ports and harbours, and for its own territory; and such regulations are valid unless they come in conflict with a law of Congress."

The decision in the Liccnse Cases reflects not only the "state's rights" constitutional principles of the Supreme Court as then constituted but the very obvious concern of the court at the prospect that the prohibition laws which a number of states were beginning to enact should be rendered ineffective by a use of interstate commerce which those states were powerless to prevent. $^{64}$

With the abatement of temperance zeal which followed the Civil War, it was more than twenty years before another grist of state laws purporting to restrain or prohibit the bringing of liquor into the state through the channels of interstate commerce claimed the attention of the Supreme Court. In 1888, however, the court threw consternation into the ranks of the prohibitionists by invalidating an Iowa statute which punished any railroad company for knowingly bringing into the state for any other person any intoxicating liquors without a certificate that the consignee was authorized to sell them. This was the case of Bowman $v$. Chicago and Northwestern $R y$. Co. ${ }^{65}$ It held that the statute was an attempt to exercise "jurisdiction over persons and property within the limits of other states" and, furthermore, "If not in contravention of any positive legislation by Congress, it is nevertheless a breach and interruption of that liberty of trade which Congress ordains as the national policy, by willing that it shall be free from restrictive regulations." The court did not cross any' unnecessary bridges in the Bozmman case, but merely held that even in the absense of conflicting federal legislation a state could not make it a crime to import an article of commerce within its borders.

64 An account of this ante-bellum prohibition movement is given in the Encyclopedia Britannica under Liquor Laws, Vol. XVI, p. 767. See also A. A. Bruce, The Wilson Act and the Constitution, (1909) 21 Green Bag 65 (1888) 125 U. S. 465, 8 S. C. R. 689, 1062, 31 L. Ed. 700. 
While the friends of prohibition in Congress were still endeavoring to enact some sort of statute which would patch up the havoc wrought by the Boiman case, ${ }^{66}$ a still greater calamity befell them in the decision of the Supreme Court early in 1890 in the case of Leisy $v$. Hardin ${ }^{67}$ This case, popularly known as the Original Package Case, overruled the decision in the License Cases $^{68}$ and held in substance that, even in the absence of congressional regulation of the subject, the police power of the sfate could not be exercised to prohibit the bringing of articles of commerce into the state and the selling of those articles in the original packages. An article of interstate commerce does not cease to be such until it has either been taken out of the original package or sold in that package; and until it ceases to be an article of interstate commerce it is beyond the reach of the state police power.

"Whatever our individual views may be as to the deleterious or dangerous qualities of particular articles [said the court] we cannor hold that any articles which Congress recognizes as subjects of interstate commerce are not such, or that whatever are thus recognized can be controlled by state laws amounting to regulations, while they retain that character. . . . To concede to a state the power to exclude, directly or indirectly, articles so situated, without congressional permission, is to concede to a majority of the pcople of a state, represented in the state legislature, the power to regulate commercial intercourse between the states, by determining what shall be its subjects, when that power was distinctly granted to be exercised by the people of the United States, represented in Congress, and its possession by the latter was considered essential to that more perfect Union which the Constitution was adopted to create."

Now it is perfectly clear that if a state cannot forbid the shipping in of intoxicating liquors from other states and canmot forbid the sale of those liquors in their original packages after they have been shipped in, then state prohibition becomes more or less of a farce. But close scrutiny of the opinion of Chief Justice Fuller in Leisy $z$. Hardin indicated to the friends of prohibition that there might still be a method of bettering this unfortunate plight of the prohibition states. Although it was unnecessary to the decision of the case, the Chief Justice had definitely

n6 These efforts are described by Lindsay Rogers, op. cit., second article, 4 Va. Law Rev. 294.

67 (1890) 135 U. S. 100,10 S. C. R. 681, 34 L. Ed. 128.

68 Supra, note 63. 
suggested at several points in his opinion that this incapacity of the states to protect themselves against interstate shipments of liquor was due to the fact that Congress had not given the states permission to exert any authority over such shipments. ${ }^{69}$ The inference from these dicta was perfectly plain: i. e., Congress might pass an act bestowing upon the states the power to pass the police regulations applicable to interstate consignments of liquor, which, in the absence of such permission, the court had held them powerless to enact. Congress, under pressure from the temperance forces, proceeded to give the states the desired permission, and the Wilson Act ${ }^{70}$ became law within a year after the decision in Leisy $v$. Hardin.

2. Congressional Permission to States to Protect Themselves from Certain Types of Interstate Commerce. The Wilson Act provided that "intoxicating liquors . . . . transported into any State or Territory or remaining therein . . . shall upon arrival . . . . be subject to the operation . . . . of the laws of such State or Territory enacted in the exercise of its police power . . . . in the same manner as though . . . . produced in such State or Territory, and shall not be exempt therefrom by reason of being introduced therein in original packages or otherwise." The Supreme Court promptly sustained the constitutionality of the act in the case of In re Rahrer. ${ }^{71}$ It is impossible to enter upon an extended discussion of the highly

$69135 \mathrm{U}$. S. at page 109: "Hence, inasmuch as interstate commerce, consisting in the transportation, purchase, sale and exchange of commodities, is national in its character, and must be governed by a uniform system, so long as Congress does not pass any law to regulate it, or allowing the states so to $d o$, it thereby indicates its will that such commerce shall be free and untrammelled."

At page 110: "If the importation cannot be prohibited without the consent of Congress, when does property imported from abroad, or from a sister state, so become part of the common mass of property within a state as to be subject to its unimpeded control?"

At page 114: "It cannot, without the consent of Congress, express or implied, regulate commerce between its people and those of the other States of the Union in order to effect its end, however desirable such a regulation might be."

At page 119: ". . . the states cannot exercise that power [to regulate commerce among the states] without the assent of Congress....."

At page 123: ".... the responsibility is upon Congress, so far as the regulation of interstate commerce is concerned, to remove the restriction upon the State in dealing with imported articles of trade within its limits. which have not been mingled with the common mass of property therein, if in its judgment the end to be secured justifies and requires such action."

The italics are the author's.

70 Act of August 8, 1890, 26 Stat. at L. 313.

71 (1891) 140 U. S. 545, 11 S. C. R. 865, 35 L. Ed. 572. 
controversial questions which came up in this case. ${ }^{72}$ The statute was attacked primarily on the grounds, first, that in passing it Congress had delegated to the states a portion of its authority over interstate commerce; and second, that it established a regulation of that commerce which was non-uniform in character. The court denied that the states had been given by the act any power to regulate interstate commerce. "Congress did not use terms of permission to the state to act, but simply removed an impediment to the enforcement of the state laws in respect to imported packages in their original condition, created by the absence of a specific utterance on its part," and it is entirely. proper for Congress to "provide that certain designated subjects of interstate commerce shall be governed by a rule which divests them of that character at an earlier period of time than would otherwise be the case." The court also denied that the act established a non-uniform regulation of commerce. Congress has "taken its own course and made its own regulation, applying to these subjects of interstate commerce one common rule, whose uniformity is not affected by variations in state laws in dealing with such property."

There is every reason to suppose that Congress in passing the Wilson Act believed that it was giving the states adequate authority to protect themselves from interstate shipments of liquor. It was not until the case of Rhodes $v$. Iow' ${ }^{i 3}$ was decided in 1898 that it became clear that the enactment of that statute and the decision of the Supreme Court sustaining its validity were but empty victories for the prohibition cause. In that case the Supreme Court decided that when the Wilson Act provides that intoxicating liquors brought into a state shall be subject to the state police power "upon arrival," the word "arrival" means, not arrival at the state line, but arrival in the hands of the one to whom they were consigned; and until such arrival they are exempt from state control or interference. ${ }^{74}$ Under this

72 See the second article by Lindsay Rogers, op. cit., 4 Va. Law Rev. 288; also A. A. Bruce, op. cit., note 64 . The article by Judge Bruce is a vigorous criticism of the Rahrer case.

73 (1898) 170 U. S. 412, 18 S. C. R. 664, 42 L. Ed. 1088 . This case reversed the decision of the Iowa supreme court in State v. Rhodes, (1894) 90 Iowa 496,58 N. W. 887,24 L. R. A. 245 , which held that under the Wilson Act shipments of liquor from other states bccame subject to the police power of the state as soon as they crossed the boundary line of the state.

74 The decision in Rhodes $v$. Iowa had been foreshadowed by the case of Scott v. Donald (1897) 165 U. S. 58, 17 S. C. R. 265, 41 L. Ed. 632,-see ałso Vance $v$. Vandercook Co.,(1898) 170 U. S. 438, 18 S. C. R. 674,42 L. Ed. 1100 ,-which held that the South Carolina dispensary system could not ex- 
construction it is apparent that the Wilson Act, instead of giving the states the virtual right to prohibit the importation of liquor by allowing them to confiscate it as soon as it reached the state line, merely gave them the right to forbid the disposition or sale of the liquor after the interstate carrier had actually delivered it to the consignee. By such a limitation on the scope of the prohilitive laws of the state so many opportunities for the evasion of those laws were opened up as to render the Wilson Act a very inconsequential gain to the temperance cause.

It may be noted in passing that in 1902 a statute practically identical in its terms with the Wilson Act was passed subjecting to the police legislation of the states, upon their arrival therein, interstate shipments of oleomargarine and other imitations of butter. ${ }^{75}$ This statute has never attracted much attention and it presents no new constitutional problem.

3. Making Articles Shipped in Interstate Commerce with Intention to Violate State Lau's Outlaws of That Commerce. (a) The Webb-Kenyon Act: No sooner had the Wilson Act been emasculated by the decision in Rhodes $v$. Iow' $a$ than agitation was begun in Congress for legislation which would actually give the prohibition states the protection against interstate shipments of liquor which that measure had been vainly supposed to provide. The problem, however, was growing increasingly difficult. Grave doubts were raised regarding the constitutionality of the various proposals for such legislation, but after considerable use of the trial and error method the Webb-Kenyon Bill was passed by Congress in 1913. ${ }^{i}$ It was vetoed by President Taft on the advice of Attorney-General Wickersham, on the ground that it was unconstitutional $; 7$ but it was promptly passed over his veto. The title of the statute described it as "An Act Divesting Intoxicating Liquors of Their Interstate Character in Certain Cases," and it proceeded to do this by prohibiting (without attaching any penalty) the shipment in interstate commerce of intoxicating liquors "intended, by any persons interested therein, to be received, possessed, sold, or in any manner used" in violation of

tend its monopolistic control of the liquor traffic in that state to the total exclusion of liquor from other states. See the third article by Lindsay Rogers, op. cit.. 4 Va. Law Rev. 355, dealing with The Narrowing of the Wilson Act.

75 Act of May 9, 1902, 32 Stat. at L. 193. The steps leading up to the passage of this act are set forth in the second article by Lindsay Rogers, op. cit., 4 Va. Law Rev. 288.

76 Act of March 1, 1913, 37 Stat. at L. 699.

it The veto message and the opinion of the attorney-general are found in Sen. Doc. 103, 63rd Congress, 1st Session. 
the law of the state of their destination. Hitherto the states had been unable to exclude shipments of liquor from other states because such action amounted to an unconstitutional prohibition of interstate commerce; under the Webb-Kenyon Act the exclusion of such liquors was made lawful by outlawing those shipments from interstate commerce and thereby depriving them of that federal protection from state regulation which articles of interstate commerce enjoy.

The Webb-Kenyon Act was held constitutional by the Supreme Court in 1917 in the case of Clark Distilling Co. $v$. Western Maryland Ry. Co ${ }^{78}$ The court pointed out that under the doctrine of the Lottery Case ${ }^{79}$ and Hoke $v$. United States ${ }^{50}$ no doubt remained as to the power of Congress to exclude intoxicating. liquor from interstate commerce altogether. The objection raised to the act was not, therefore, "an absence of authority to accomplish in substance a more extended result than that brought about by the Webb-Kenyon Law, but . . . . a want of power to reach the result accomplished because of the method resorted to." This method was not unconstitutional on the ground that it delegated power to the state to prohibit interstate commerce in intoxicating liquors (the argument on which President Taft's veto was based) and thereby permitted the nonuniform regulation of such commerce; the court declared that the argument as to the delegation of power to the states rested upon a misconception: ". . . the will which causes" the prohibitions to be applicable is that of Congress, since the application of state prohibitions would cease the instant the act of Congress ceased to apply." In regard to the alleged non-uniformity of commercial regulation the court declared: " . . . . there is no question that the act uniformly applies to the conditions which call its provisions into play-that its provisions apply to all the states-so that the question really is a complaint as to the want of uniform existence of things to which the act applies, and not to an absence of uniformity in the act itself." Having disposed of these objections the court could "see no reason for saying that although Congress, in view of the nature and character of intoxicants had power to forbid their movement in interstate commerce, it had not the authority so to deal with the subject as to establish a regulation (which is what was done by

78 (1917) 242 U. S. 311, 37 S. C. R. 180, 61 L. Ed. 326.

79 Supra. p. 386.

80) Supra, p. 390. 
the Webb-Kenyon Law) making it impossible for one state to violate the prohibitions of the laws of another through the channels of interstate commerce." ${ }^{81}$

(b) The Lacey Act: In 1900 Congress passed a statute making it unlawful to ship from one state or territory to another state or territory any animals or birds killed in violation of the laws of the state. ${ }^{82}$ It is quite clear that Congress was here using its power over interstate commerce for the purpose of co-operating with the states in the protection of wild game and birds. In fact, the first section of the statute declared frankly that its purpose was to "aid in the restoration of such birds in those parts of the United States adapted thereto where the same have become scarce or extinct." It should be noticed that this act differs in theory from the Webb-Kenyon Act, because the articles' which are here outlawed from interstate commerce are not articles which when distributed through that commerce will menace the public welfare. They are outlawed because of their illegal origin and possession and because Congress desires to prevent interstate commerce from being used as an outlet or place of refuge for such illegal commodities. By passing the Webb-Kenyon Act Congress refused to allow itself to become an accessory before the fact, by declining to place the facilities of interstate commerce at the disposal of those who are about to violate the prohibition laws of the states; by passing the Lacey Act Congress refused to become an accessory after the fact, by declining to place those facilities at the disposal of those who have just violated the state law by affording them a means of disposing of their unlawful possessions. This difference, however, should have no bearing upon the question of congressional power to pass the Lacey Act, and the only court which has passed upon its validity has held it constitutional on the authority of the Rahrer case upholding the Wilson Act. ${ }^{83}$

81 The Webb-Kenyon Act and the Clark Distilling Co. case have been widely discussed in the legal periodical literature. The following articles may be mentioned here: D. O. McGovney, The Webb-Kenyon Law and Beyond, 3 Iowa Law Bul. 145: S. P. Orth, The Webb-Kenyon Law Decision, 2 Corn. Law Quar. 283; T. R. Powell, The Validity of State Legislation Under the IVebb-Kenyon Law, 2 So. Law Quar. 112; Lindsay Rogers, The Webb-Kenyon Decision, 4 Va. Law Rev. 558. Other articles are cited in the notes to Decisions of the Supreme Court of the United States on Constitutional Questions, T. R. Powell, 12 Amer. Polit. Science Rev. 19 et seq.

82 Act of May 25, 1900, 31 Stat. at L. 188.

83 Rupert v. United States, (1910) 181 Fed. 87. 
4. The Reed "Bone-Dry" Amendment. The introduction for discussion at this point of the Reed Amendment by its popular title rather than by a caption indicating the principle on which it is based is a confession by the author of his inability to discover what that principle is, if there be any. This act was passed as an amendment to the Postoffice Appropriation Act of 1917. ${ }^{84}$ The pertinent provision reads as follows: "Whoever shall order, purchase, or cause intoxicating liquors to be transported in interstate commerce, except for scientific, sacramental, medicinal, and mechanical purposes, into any state or territory the laws of which state or territory prohibit the mamufacture or sale therein of intoxicating liquors for beverage purposes shall be punished as aforesaid." "85

A casual reading of this statute might lead one to assume that Congress had merely supplemented the Webb-Kenyon Act by punishing those who make interstate shipments of liquor which, in order to divest them of their interstate character, that act had prohibited without attaching a penalty. What the Reed Amendment really does is to impose, under penalty of the federal law, a "bone-dry" policy in the matter of shipments of liquor from other states upon any state which prohibits merely the manufacture and sale of intoxicants for beverage purposes. In other words, the amendment forbids the shipment of liquor even for personal use into a state which may permit the personal use of liquor but forbids its manufacture and sale.

The Supreme Court recently upheld the validity of the Reed Amendment in the case of United States $v$. Hill. ${ }^{86}$ It was urged

84 Act of March 3, 1917, 39 Stat. at L. 1069. The same act also prohibited sending liquor advertisements through the mails into states which forbade such advertising. See J. K. Graves, The Reed "Bone Dry" Amendment, 4 Va. Law Rev. 634.

85 Italics are the author's.

86 (1919) 248 U. S. 420, 39 S. C. R. 143. In McAdams v. Wells Fargo \& Co. Express, (1918) 249 Fed. 175, the law was enforced against the carrier and the court said: "It is quite evident that Congress, in adopting said act, intended to aid the states in the enforcement of their prohibition laws...... It may be that Congress builded better than it knew in passing the Act of March 3,1917; but there is no doubt that it prohibits the shipment of liquor in interstate commerce for beverage purposes into the dry parts of the state of Texas wherein the sale of liquor is prohibited by the state law. though intended only for personal use." In United States v. Mitchell, (1917) 245 Fed. 601, the court, while not declaring the Reed Amendment unconstitutional, held that the transportation of liquor for personal use in one's own baggage is not "commerce" and does not therefore fall within the prohibitions of the act. The view is, of course, in conflict with the decision of the Supreme Court in the Hill case. 
upon the court, and the lower court so held, that the prohibition of the act should be construed to apply only to such shipments of liquor as were in violation of the law of the state into which they went. But the Supreme Court refused to narrow the meaning of the act in this way. The illegality of the forbidden shipments of liquor does not depend upon the law of the state, as it does in the case of the Webb-Kenyon Act, but upon the law of Congress. While Congress may exercise its authority over interstate commerce "in aid of the policy of the state, if it wishes to do so, it is equally clear that the policy of Congress acting independently of the states may induce legislation without reference to the particular policy or law of any given state." It is well established that in certain cases congressional regulation of commerce may take the form of prohibition, and this is an appropriate case for the exercise of that power. "That the state saw fit to permit the introduction of liquor for personal use in limited quantity in no wise interferes with the authority of Congress, acting under its plenary power over interstate commerce, to make the prohibition against interstate shipment contained in this act. It may exert its authority, as in the Wilson and Webb-Kenyon Acts, having in view the laws of the state, but it has a power of its own, which in this instance it has exerted in accordance with its view of public policy."

A brief but vigorous dissenting opinion was written by $\mathrm{Mr}$. Justice McReynolds. He expressed his conviction that the Reed Amendment "in no proper sense regulates interstate commerce, but it is direct intermeddling with the states' internal affairs.

to hold otherwise opens possibilities for partial and sectional legislation which may destroy proper control of their own affairs by the separate states . . . . If Congress may deny liquor to those who live in a state simply because its manufacture is not permitted there, why may not this be done for any suggested reason-e. g., because the roads are bad or men are hanged for murder or coals are dug? Where is the limit?

. The Reed Amendment as now construed is a congressional fiat imposing more complete prohibition wherever the state has assumed to prevent manufacture and sale of intoxicants."

There is nothing in the majority opinion in the Hill case to throw any light upon Mr. Justice McReynolds' question, "Where is the limit?" The law classifies the states and prohibits the shipment of liquor for beverage purposes into the states comprising 
one of the classes. But there is nothing to indicate that the court regarded the constitutionality of the law as in any way contingent upon the intrinsic reasonableness of that classification. Emphasis is laid upon the fact that Congress could exclude all liquor from interstate commerce, and the suggestion that the Reed Amendment depends for its prohibitive force upon the existence of any particular type of state law relating to liquor is repudiated. The court does suggest that Congress apparently thought it would be a good thing to impose the "bone-dry" rule upon all states having more moderate prohibition laws, but this is far from saying that the statute would not have been an equally legitimate exercise of the commerce power if the purpose of Congress had been something quite remote from the suppression of the liquor traffic. If Congress has full power to stop all interstate traffic in liquor, but is under no constitutional obligation to prohibit the shipment of liquor into all states merely because it prohibits such shipments into some, being free to make the application of that prohibition depend upon the existence or non-existence of certain conditions in the states, then may not Congress by turning the interstate spigot on or off, as the needs of the case may demand, exert a pressure on the states which will lead them to comply with the congressional wishes in matters over which Congress has no direct authority? It is not impossible that Congress has stumbled inadvertently into an unexplored field of police regulation, although there is small probability that such an indirect method of exerting police power would ever prove particularly alluring.

Whatever may be the constitutional implications of the Reed Amendment and the case upholding it, it is impossible to classify it with any of the types of national police regulation which have been thus far discussed. It is not an exclusion from interstate commerce of a commodity which Congress regards as injurious to the national health or morals, because Congress docs not exclude all liquor from such commerce, but only that destined for certain states. Nor is it an act designed to co-operate with the states in the adequate enforcement of their police regulations relating to the liquor traffic, because it overrides the wishes of many of those states and imposes on them a more rigorous prohibition than they desire. It embodies neither the principle of positive national control over the interstate shipments of liquor nor the principle of local option or state home rule enbodied 
in the Wilson and Webb-Kenyon Acts. It proceeds upon the somewhat curious theory that Congress ought to impose its own brand of prohibition not upon all the states but only upon those states which have seen fit to adopt another sort of prohibition.

From the ground thus far covered it is apparent that the police power which Congress may exercise in protecting and promoting interstate commerce, substantial as that power has been shown to be, has been overshadowed by the police power resulting from the efforts of Congress to keep that commerce from being used to distribute objectionable commodities or to promote objectionable transactions. The goods or transactions which may thus be excluded from interstate commerce may be objectionable either because they are dangerous to the public morals, health, or welfare, or because they are to be used in violation of the legitimate police regulations of the state. The question which remains for consideration is whether or not a still more extensive national police power may properly be derived from the commerce clause by allowing Congress to deny the privileges of interstate commerce to commodities which are harmless in their nature and the use to which they are to be put, but which are produced under conditions which Congress deems objectionable. This problem will be dealt with in the concluding section of this article. 

THE NATIONAL POLICE POWER

UNDER THE

COMMERCE CLAUSE OF THE CONSTITUTION*

IV. Regulations Denying the Privileges of Interstate Commerce to Harmless Goods Produced under

Objectionable Conditions-The Federal

Child Labor Law

In PASSING the Keating-Owen Child Labor Law ${ }^{1}$ Congress plunged, probably with some misgivings, into what was expected to prove a new field of national police regulation. The act forbade the shipment in interstate commerce of the products of mines and factories in which, within thirty days prior to their shipment in such commerce, child labor had been employed. It was an entirely novel exercise of the power to regulate commerce. Even those who deny that the unique character of the act created any serious constitutional difficulty readily agree that it stands in a class by itself as an exercise of congressional authority. Hitherto Congress had exercised a national police power under the commerce clause in two general ways: first, to protect interstate commerce from injury and obstruction; second, by refusing to allow it to be used to further the distribution of obnoxious commodities or the consummation of injurious designs. Wherever Congress had resorted to prohibitions of interstate commerce the prohibition had been justified upon the harmful nature of the thing excluded; harmful either to commerce itself or harmful in the use to which it was put. The goods excluded by the Child Labor Law, however, were themselves entirely harmless and legitimate in character, and harmless and legitimate also in the use to which they were to be put; their harmfulness consisted in the fact that they were produced under conditions injurious to the public welfare. Like an illegitimate child, they were made to bear the taint of the evil which brought them into existence; the disability which attached to them was created not because Congress in any way objected to having that kind of goods distributed through interstate commerce but

*Continued from 3 Minnesota Law Review 412.

1 Act of September 1, 1916, 39 Stat. at L. 675, Chap. 432. 
because it wished to make it unprofitable to employ children in the manufacture of any kind of goods. The doctrine of the Child Labor Law would have extended enormously the scope of the national police power under the commerce clause by placing within congressional regulation the conditions, under which any articles of interstate commerce are produced.

The history of the movement for a federal child labor law shows that movement to have been in the main a trial and error search for constitutionality. The most dangerous opposition to such a law did not come from the friends of child-labor, a group which grows constantly smaller and more silent; nor did it come from the "states rights" advocates, who, on grounds of policy and expediency, objected to the placing of child labor under uniform national control-for few intelligent persons are now prepared to deny that there is small hope for an effective suppression of the child labor curse in the divergent legislation of forty-eight states. On the contrary, the opposition which counted most came from those who, while sympathising with the objects of the law, honestly doubted that there was any sound constitutional basis upon which a child labor law under the commerce clause could rest; who, in the apt phrase of one of their number, could not convince themselves "that 'accroachment of power' is expedient when benevolent, and that, though a child is entitled to protection, the constitution is not." 2 This was apparent from the very outset. The first federal child labor bill was introduced into the Senate in 1906 by Senator Albert J. Beveridge of Indiana. This pioneer bill forbade any interstate carrier to transport the products of any mine or factory in which children under fourteen years of age were employed; and to make the bill effective the management of any establishment desiring to ship goods in interstate commerce was compelled to give the common carrier a statement that no such children were employed in its plant. ${ }^{3}$ In a brilliant speech extending over three

2 Green. The Child Labor Law and the Constitution, Ill. Law Bul., April, 1917, p. 6.

${ }^{3}$ The portions of this bill which are of interest in this connection are as follows: "Be it enacted.. That six months from and after the passage of this act no carrier of interstate commerce shall transport or accept for transportation the products of any factory or mine in which children under fourteen years of age are employed or permitted to work, which products are offered to said interstate carrier by the firm, person, or corporation owning or operating said factory or mine, or any officer or 
days Senator Beveridge set forth the need for such legislation and defended its constitutionality. ${ }^{4}$ The most distinguished legal talent in the Senate was drawn into this debate; and it was plain to see that with but few exceptions their views of its validity ranged from skepticism to the clear conviction that it was unconstitutional. $^{5}$ The bill never became law, and the Judiciary Committee of the House of Representatives to which it was referred made a report setting forth its belief that the bill was clearly invalid. ${ }^{6}$ With the retirement of Mr. Beveridge from the Senate, the active efforts of congressmen to secure federal legislation upon the problem of child labor for the time being ceased.

The Keating-Owen bill was the successor to the Beveridge bill. As introduced into the House, it forbade the shipment in interstate commerce of goods produced in whole or in part by the labor of children under fourteen years of age. This bill was not wholly satisfactory to the National Child Labor Committee which was sponsoring it, because placing the prohibition merely upon child-made goods narrowed considerably the scope of the act; though there was a belief that a stronger argument could be made for its constitutionality than for one broader in

agent or servant thereof, for transportaton into any other state or territory than the one in which said factory is located.

"Sec. 2. That no carrier of interstate commerce shall transport or accept for transportation the products of any factory or mine offered it for transportation by ariy person, firm, or corporation which owns or operates such factory or mine, or any officer, agent, or servant of such person, firm, or corporation, until the president or secretary or general manager of such corporation or a member of such firm or the person owning or operating such factory or mine shall file with said carrier an affidavit to the effect that children under fourteen years of age are not employed in such factory or mine." The full text of this bill may be conveniently found at page 56 of the supplement to vol. XXIX, Annals of the American Academy, etc., (1907).

4 Cong. Rec. vol. 41, pp. 1552-1557, 1792-1826, 1867-1883.

${ }^{5}$ It was probably doubt as to the constitutionality of the Beveridge bill which led Senator Lodge to introduce a rival bill (S. 6730) on December 5,1906 , which provided: "That the introduction into any state or territory or the District of Columbia, or shipment to any foreign country, of any article in the manufacture or production of which a minor under the age of fourteen years has been engaged is hereby prohibited." The second section applied a similar prohibition to goods made by children between fourteen and sixteen years, except those made by "any minor between the ages of fourteen and sixteen years to whom has been granted a certificate" by various school authorities "testifying to the fact that he or she is able to read and write the English language." This bill was referred to the Committee on Education and Labor, but it seems never to have attracted much notice or discussion.

${ }^{6}$ House Rep. No. 7304, 59th Cong.. Second Session. Part of the argument of this committee is quoted in Watson, Constitution, I, pp. 532-534. 
scope. When the bill came before the Committee on Interstate Commerce in the Senate it was changed into the form in which it was finally enacted, a form which made it a far more effective law. ${ }^{7}$ In this form it forbade not merely child-made goods but the products of any mine or factory in which children were employed. The President signed the bill September 1, 1916, and by its terms it became effective September 1, 1917. Almost immediately a bill was filed in a federal district court in North Carolina by a father on behalf of himself and his two minor sons asking for an injunction against the enforcement of the act. The district court held the act unconstitutional, ${ }^{8}$ and an appeal was taken to the Supreme Court of the United States. On June 3, 1918, the Supreme Court handed down a five to four decision invalidating the law. ${ }^{9}$

Few questions have arisen in recent years in our constitutional law upon which the professional opinion of the country has been more evenly divided. Few questions have called forth on both sides abler or more convincing arguments. Discussion of the question had been kept up intermittently during the dozen years between the introduction of the Beveridge bill and the decision of the Supreme Court upon the constitutionality of the KeatingOwen Act; and that decision, rendered as it was by an almost evenly divided court with a vigorous dissenting minority, called

7 An account of the legislative history of the bill is found in Pamphlet No. 265 of the National Child Labor Committee (1916).

The relevant portion of this act is as follows: "Be it enacted

That no producer, manufacturer, or dealer shall ship or deliver $\dot{f} \cdot \overrightarrow{\text { in }}$ ment in interstate or foreign commerce any article or commodity the product of any mine or quarry, situated in the United States, in which within thirty days prior to the time of the removal of such product therefrom children under the age of sixteen years have been employed or permitted to work, or any article or commodity the product of any mill, cannery, workshop, factory, or manufacturing establishment, situated in the United States, in which within thirty days prior to the removal of such product therefrom children under the age of fourteen years have been employed or permitted to work, or children between the ages of fourteen years and sixteen years have been employed or permitted to work more than eight hours in any day, or more than six days in any week, or after the hour of seven o'clock postmeridian, or before the hour of six o'clock antemeridian."

${ }^{8}$ No opinion was written. This decision was rendered by the same judge who, according to press reports, has recently declared unconstitutional the clause of the Revenue Act of Feb. 24, 1919, placing a ten per cent excise tax upon the net profits of businesses employing children.

${ }^{9}$ Hammer v. Dagenhart, (1918) 247 U. S. 251, 62 L. Ed. 1101, 38 S. C. R. 529. 
forth a new grist of opinion. ${ }^{10}$ Even now the layman who approaches the problem without definite preconceptions is greatly in danger of experiencing a painful instability of opinion and of finding himself landed finally on the side of the advocate or critic to whose arguments he last gave ear.

There would be small justification for the writer to add to the already voluminous literature on the subject another argument for or against the validity of the federal Child Labor Law. However, a discussion of the national police power under the commerce clause would hardly be complete without some attempt to classify the precise constitutional issues involved in this attempt to extend that power so radically. An effort will be made, therefore, to set forth as plainly and fairly as possible the arguments which have been advanced, first by those who have believed the act to be unconstitutional and second by those who have regarded it as valid. In each case the reasoning of the majority and minority, respectively, of the Supreme Court will be briefly summarized as fitting conclusions to the briefs.

\section{The Argument Against the Constitutionality of the Law}

Inasmuch as the constitutionality of a law is to be presumed until disproved, it will be appropriate to present first the arguments of those who have attacked the validity of the law. ${ }^{11}$ These arguments quite naturally differ a great deal in persuasiveness, in thoroughness of reasoning, and in the emphasis placed upon the different points considered. In spite of this diversity it is possible to melt them all together into a brief composed of three major arguments, which will be considered separately. The writer has made no special effort at originality in setting forth

${ }^{10}$ While there are differences between the provisions of the Beveridge bill and the Keating-Owen Act, these differences are largely in the method used to accomplish the legislative purpose and not differences in constitutional principle. The fundamental issue of constitutionality seems to be the same in both, and the arguments for and against the measures are applicable to both alike.

11 In addition to the arguments presented in the debate in Congress above referred to (see note 4 , supra), the Beveridge bill was criticized on constitutional grounds by the following writers: Bruce, The Beveridge Child Labor Bill and the United States as Parens Patriae, (1907) 5 Mich. Law Rev. 627; Maxey, The Constitutionality of the Beveridge Child Labor Bill, (1907) 19 Green Bag 290; Knox, Development of the Federal Power to Regulate Commerce, (1908) 17 Yale Law Jour. 135; Willoughby, Constitution, II, Sec. 348; Watson, Constitution, I, pp. 523-534. Before the 
these arguments, but has attempted to present a sort of composite picture made up of all of them, a picture in which, as in the real composite photograph, the details of each component are lost to view, but in which the common characteristics stand out vividly.

1. It Is Not a Regulation of Commerce. It is important to bear in mind that Congress has no power to deal openly and directly with the evil of child labor. It merely has the right to regulate interstate commerce. Therefore, while the federal Child Labor Law was admittedly passed for the purpose of driving child labor out of existence, it was compelled, from the standpoint of constitutional law, to seek justification not as a child labor law but as a regulation of interstate commerce. If it can be shown that the law is not a regulation of interstate commerce, then its constitutional underpinning collapses and it must be regarded as an attempt by Congress to exercise a power which it does not possess under the constitution. Probably without exception the opponents of the law have built their case around this central and vital point, that it is not a regulation of commerce. The arguments advanced in support of this proposition may be set forth as follows :

(a) Not Every Regulation Dealing with Commerce Is a Regulation of Commerce in the Constitutional Sense: The fact that the Child Labor Law is entitled "An Act to Prevent Interstate Commerce in the Products of Child Labor, and for Other Purposes," coupled with the fact that the thing which the law punishes is not the employment of children, but the shipment in interstate commerce of certain commodities, raises an initial presumption that it is a regulation of commerce. Constitutional

Keating-Owen Act was declared invalid, its constitutionality was attacked in the following articles: Green, The Child Labor Law and the Constitution, Ill. Law Bul., April, 1917; Gleick, The Constitutionality of the Child Labor Law, (1918) 24 Case and Com. 801; Hull, The Federal Child Labor Law, (1916) 31 Pol. Sci. Quar. 519; Krum, Child Labor, (1917) 24 Case and Com. 486. See also the general criticism in Hough, Covert Legislation and the Constitution, (1917) 30 Harv. Law Rev. 801. The decision of the Supreme Court in Hammer v. Dagenhart, supra, note 9. was discussed with approval in the following articles: Berry, The Police Power of Congress under Authority to Regulate Commerce. (1918) 87 Cent. Law Jour. 314 ; Bruce, Interstate Commerce and Child Labor. (1919) 3 Minnesota LAw Review 89; Green, Social Justice and Interstate Commerce. (1918) 208 North Amer. Rev. 387; and note, (1919) 2 I11. Law Bul. 126: Taft, The Power of Congress to Override the States, (July, 1918) 15 Open Shop Rev. 273. See also editorial (1918) in 86 Cent. Law Jour. 441. 
phrases must not, however, be construed "with childish literalness." It must not be naively assumed that everything which is labeled a regulation of commerce or which in some way affects conmerce is a regulation of commerce in the constitutional sense. The extent and nature of the power of Congress over interstate conmerce must be interpreted in the light of the purposes for which the power was granted. ${ }^{12}$ For instance, the governments of the state and nation enjoy a power of taxation which in "the extent of its exercise is in its very nature unlimited;"13 yet when the state of Kansas authorized a city to levy a tax for a private and not a public purpose the Supreme Court of the United States declared that the levy was not a tax, merely "because it is done under the forms of law and is called taxation," but was "a decree under legislative forms." ${ }_{14}$ In like manner the Child Labor Law is not necessarily a regulation of commerce simply because it is done under the forms of law and is called "a regulation of commerce."

(b) Power to Regulate Interstate Commerce Was Given to Promote and Not to Destroy Commerce: If we had no light whatever upon the purposes for which the power to regulate commerce was given to Congress by the framers of the constitution, it would still be reasonable to argue that the power to "regulate" does not include any general power to "destroy" or to "prohibit" commerce. A grant of "the power to regulate necessarily implies the existence of the thing to be regulated."15 Where power has been given to state legislatures or city councils to "regulate" the liquor traffic the courts have held that no authority was thereby given to "prohibit" such traffic. ${ }^{10}$ It is logical to assume that the power to regulate commerce should be thoughi of as "a power to regulate acts of commerce so as to promote the good or prevent the evil that might flow from those acts."17 While it might properly include the power to make all necessary rules to protect commerce and promote its efficiency and to pre-

12 This point is clearly developed by Professor Green, op. cit., Ill. Law Bul., note 11, supra. 455.

${ }^{13}$ Loan Association v. Topeka. (1874) 20 Wall. (U.S.) 655; 22 L. Ed.

14 Ibid.

15 Watson. Constitution. I. p. 532, citing State v. Clark, 54 Mo. 17 ; State v. McCann, 72 Tenn. [4 Lea] 1.

${ }^{16}$ Watson, op. cit., p. 532.

1; Green, op. cit., Ill. Law Bul. 13. 
vent the injury to the national welfare which might flow from the acts and transactions of conmerce, it cannot be held to include the authority to prohibit commerce in innocent and harmless commodities.

But we are not entirely in the dark as to the purposes for which the "fathers" placed the power to regulate commerce in the hands of Congress. While the debates in the Convention of 1787 do not throw much light on the subject, the whole history of the Confederation as well as the contemporary literature of the period would seem to indicate a hope and desire that Congress would bring about freedom of commercial intercourse, freedom which would replace the oppressive and mutually retaliatory obstructions which emanated from the jealousies of the separate states. There was apparently no thought that Congress was being given power by the new constitution to prohibit commerce in legitimate articles because it disapproved of the local conditions under which they were produced. While the Convention of 1787 went out of its way to forbid in express terms any congressional interference with the importation of slaves prior to $1808,{ }^{18}$ yet it made no effort to prevent Congress from excluding from commerce the products of slave-labor,an exclusion clearly in line with the Child Labor Law-quite as though it assumed that Congress had no such authority. Certainly it can hardly be believed that either the framers of the constitution or the conventions which ratified it had any idea that they had given to Congress any power under the commerce clause to knife the institution of slavery in the back.

It has been forcefully argued that since, prior to the adoption of the constitution, the several states enjoyed full and sovereign power to prohibit commerce with the other states, as any independent nation might prohibit it, and that since the states gave up their power to Congress and made that power of Congress plenary and exclusive, it must therefore follow that Congress received all the power that the states gave up. ${ }^{19}$ Otherwise what became of it? The answer is that it went back into the hands of the people, the same "people" who hold all the other powers of government "not delegated to the United States by the Con-

18 Art. I, Sec. 9. On this point see Green, op. cit., North Amer. Rev. note 11 , supra.

19 Infra, p. 472. 
stitution" nor "reserved to the States respectively."20 Indeed, it is quite within reason to suppose that the framers of the constitution consciously intended to wipe out of existence entirely any power to prohibit interstate commerce in legitimate commodities by withdrawing that power from the individual states which had abused it and by failing to confer it upon Congres: which might abuse it.

(c) In Its Real Purpose and Effect the Law Has Nothing to Do with Interstate Commerce: The contention that the Child Labor Law is not a regulation of interstate commerce in the constitutional sense has been most frequently and cogently grounded upon the fact that the purpose and effect of the act is to prohibit child labor, something quite remote from the act of shipping commodities in interstate commerce. "Its purpose and effect are to benefit children and not to benefit commerce."21 Thus the statute is looked upon as somehow fraudulent, or misbranded. This argument is presented in several ways.

It has been urged by some that the Child Labor Law is in effect a denial by Congress of the privileges of interstate commerce as a penalty for doing things of which Congress does not approve but which it has no power to prohibit directly. This has been aptly expressed in this way: "Plainly the reason for the statute must be stated in the first instance in this form: "The state does not like what you are doing. Therefore it has forbidden you to do something else-ship certain goods-not because that is in the least degree objectionable, but because the state thinks it can in this way make you so uncomfortable that you will quit employing children." ${ }^{22}$ In commenting on the case in which the Supreme Court held the law invalid, exPresident Taft said: "The majority of the court decided that this was an attempt by Congress to regulate the use of child labor in the state. Will any man say that this was not its purpose? It was a congressional threat to the state, 'Unless you make your labor laws to suit us we shall prevent your use of interstate commerce for the sale of your goods." ",23 In short, when Congress uses its power over commerce as a "club for belaboring persons

${ }^{20}$ Constitution of the United States, Amendment X.

${ }^{21}$ Green, op. cit., I11. Law Bul., note 11, supra.

22 Ibid.

${ }^{23} \mathrm{Taft}$, op. cit., note 11 , supra. 
whose habits it does not approve," ${ }^{24}$ its action ought in reason to be regarded as a regulation not of the club but of the tling or person clubbed.

Others have laid emphasis in this connection on the fact that the statute is in effect a regulation of manufacturing or production. It is then pointed out that manufacturing is antecedent to and wholly separate from commerce and transportation and that the authority of Congress extends only to the latter. ${ }^{25}$

It is further suggested that the purpose and effect of the act is to regulate the relations between employers and employees who are not themselves engaged in the processes of interstate commerce, and to regulate them in respect to a matter that in no way concerns interstate commerce,-namely, the age of the employee. In the Adair case ${ }^{26} \mathrm{Mr}$. Justice Harlan pointed out that a regulation of the relations between master and servant in respect to the membership of employees in a labor union did not bear sufficiently close connection to interstate commerce to be regarded as a legitimate regulation of that commerce. The regulation imposed upon employers by the Child Labor Law is thought to be still less closely related to interstate commerce.

It is quite natural that those who attack the Child Labor Law on the ground that it is too remote from interstate commerce to be a legitimate regulation of it should be challenged to show that the law is less a regulation of commerce than the Lottery Act, the Pure Food Act, the White Slave Act, and the other statutes by which Congress has prohibited commerce in various commodities. The friends of the law claim that the only possible distinction between the Child Labor Law and these other acts the validity of which is no longer open to question is that in the one case Congress uses its power over interstate commerce to protect the producer and in the other case to protect the consumer. This distinction, it is urged, is wholly irrelevant and immaterial so far as any question of the constitutional limits of

24 Green, op. cit., North Amer. Rev., note 11, supra.

25 The cases usually relied on to support this view are United States v. E. C. Knight Co., (1895) 156 U. S. 1, 39 L. Ed. 325, 15 S. C. R. 249 ; Kidd v. Pearson, (1888) 128 U. S. 1, 32 L. Ed. 346, 9 S. C. R. 6; In re Greene, (1892) 52 Fed. 104.

${ }^{26}$ Adair v. United States, (1908) 208 U. S. 161, 52 L. Ed. 436, 28 S. C. R. 277, 13 Ann. Cas. 764. Professor Goodnow severely criticizes the use of the Adair case as an authority to prove the Child Labor Law not a regulation of commerce. See Social Reform and the Constitution, 87. 
congressional power over commerce is concerned, since there is nothing in the constitution nor in the decisions of the Supreme Court to indicate that the consumer is any more entitled to protection through any exercise of the commerce power than is the producer. ${ }^{27}$

It seems clear that this distinction between regulations which guard the interests of the consumer and those which seek to improve the condition of the producer has been given a prominence by writers on both sides of this controversy which has tended to obscure what the opponents of the law regard as the vital distinction between it and the police regulations which Congress has previously enacted under the commerce clause. This distinction is that in the Lottery and White Slave Acts Congress has used its power over interstate commerce to prevent evils which might be said to result in the sense of actual causation from the acts or processes of interstate commerce. "In all of these cases, the introduction of the thing carried into the state is an act of evil tendency. Introducing it contributes to produce evil; it is a part of a course of action by which evil is consummated."2s These acts are all "regulations of commerce made with a view to the results that may flow from the commerce regulated; to prevent evils that, unregulated, it might produce, or to promote benefits that, unregulated, it might not produce."'29 But the Child Labor Law does not prevent any evil which can be said to result from the acts or transaction of interstate commerce. The curse of child labor cannot be said to be promoted by the freedom of the employer of children to ship his products in interstate commerce simply because he might cease to employ children if that freedom were denied to him, any more than it can be said that child labor is promoted by free education because those who now employ children might cease to do so if, because of that, they were denied the right to send their children to the public schools. It cannot be said, therefore, that when Congress passed the Child Labor Law it was preventing the use of interstate commerce as a means of promoting a national evil, since the evil in question is not in any reasonable sense promoted by the uninterrupted flow of interstate commerce. This fact makes clear the distinc-

27 Infra, p. 475.

${ }^{28}$ Green, op. cit., North Amer. Rev., note 11, supra.

29 Ibid. 
tion between this act and the other instances in which Congress has exercised police power under the commerce clause.

It would seem that those who regard the Child Labor Law as just as real and thoroughgoing a regulation of commerce as the Lottery Act or the White Slave Act have trod, perhaps unconsciously, the following steps: (1) By passing these regulations of commerce, the Lottery Act and so forth, Congress has openly intended to protect the public morals, health, and safety, and has exercised a police power. (2) Therefore Congress enjoys a broad police power in the exercise of which it may set up any type of control over interstate commerce which will result in benefit to the public morals, health, and safety. (3) The exclusion of the output of child labor factories from interstate commerce will result in great good to the nation by safeguarding its children. (4) Therefore the Child Labor Law is a proper exercise of this police power of Congress under the commerce clause and should be regarded with no more suspicion or disfavor than the White Slave Act or the Lottery Act, which have also protected the national health, morals, and general welfare. Now the opponents of the Child Labor Law believe that there is a non sequitur between (1) and (2). It does not follow from the authority of the Lottery $\mathrm{Case}^{30}$ and the Hoke ${ }^{31}$ case that Congress has a police power unlimited in scope and limited only in the means available for its exercise. Congress has police power, but only such as can be exercised within the limits of the domain under congressional control-interstate commerce. This police power extends to the suppression of any evil which threatens interstate commerce or arises from or is being consummated by that commerce. Now the evil of child labor does not exist within the domain of interstate commerce; it exists where the children are employed. "The menace in the case of child labor is over and done with when the product is manufactured.

The exercise of the police power in prohibiting the use of interstate transportation for such products will operate of course as a deterrent. But it seems clear that thereby the police power becomes operative outside of the domain of interstate commerce. And beyond the borders of that domain the police power of

30 (1903) 188 U. S. 321, 47 L. Ed. 492, 23 S. C. R. 321.

31 (1913) 227 U. S. 308, 57 L. Ed. 523, 33 S. C. R. 281. 
Congress, like the king's. writ beyond his kingdom, does not run." ${ }^{32}$

This is not a matter of inquiring into congressional motives and invalidating a law because those motives were disingenuous. It is purely a question of power. The act fails as a regulation of commerce not because its purpose and effect are to prohibit child labor but because the child labor prohibited has nothing to do with interstate commerce. If interstate railroads employed children, Congress could doubtless forbid the employment of children in interstate commerce, just as it has prevented cruelty to animals while they are being transported by an interstate carrier. ${ }^{33}$ Such a law would deal with an evil which existed within the domain of interstate commerce and not an evil which is over and done with before the commerce the power to regulate which forms the basis of congressional action begins.

The opponents of the Child Labor Law argue further that the extensive and arbitrary power which Congress has used to prohibit foreign commerce in various commodities constitutes no authority for the exercise of a similar power over interstate commerce. The power of Congress over foreign commerce is more extensive than over interstate commerce. Several reasons support this view. In the first place, the commerce clause is not the exclusive source of the power which Congress enjoys over foreign commerce. The power over foreign commerce derived from the commerce clause is supplemented by the power derived from the sovereign authority of the federal government to regulate its relations with other countries. ${ }^{34}$ In the second place, assuming that the word "regulate" used in the commerce clause means the same and bestows the same power upon Congress in regard to both interstate and foreign commerce, nevertheless there are certain constitutional limitations which operate as restrictions upon congressional power over interstate commerce which do not apply to foreign commerce in the same way. The dissenting opinion of Chief Justice Fuller in the Lottery Case ${ }^{35}$ suggests that the power of Congress over interstate commerce is subject to a limitation growing out of the "implied or reserved power in the states" which would not apply to the regulation of

32 Hull, op. cit., 524, note 11 , supra.

33 Act of Mar. 3, 1891, 26 Stat. at L. 833.

34 Willoughby, Constitution, Secs. $64,66,374$, with cases cited.

35 Note 30 , supra. 
interstate commerce. This amounts to invoking indirectly the Tenth Amendment as a restriction on the power over interstate commerce. It has been intimated elsewhere by the court as well as by other authorities that while the complete prohibitions of foreign commerce would not deprive any one of property without due process of law, since no individual has a right to trade with foreign nations, ${ }^{36}$ a similar prohibition of interstate commerce might under many circumstances amount to a denial of due process of law by invading the constitutional right of the citizen to engage in such commerce. In the third place, in spite of numerous dicta in early opinions to the effect that the scope of congressional authority over the two kinds of commerce is identical, there is not a single case, out of all that have afforded an opportunity for such a decision, in which the Supreme Court has decided squarely that it is. ${ }^{37}$

In similar manner it is pointed out that the police power which Congress has exercised through its control over the postal system, a power which has been used to exclude from the mails a wide variety of things, does not constitute any authority for the power used to pass the Child Labor Law. In the first place, it is impossible to mention any act by which Congress has actually excluded any commodity from the mails because of the objectionable character of the conditions under which it was produced; and in the second place, the power of Congress over the postal system is broader than over interstate commerce, inasmuch as Congress has explicit authority to "establish post offices and post roads," ${ }_{38}$ while in respect to interstate commerce the power given is not to "establish" but to "regulate." It may very properly be argued that no one is deprived of any property right without due process of law by being denied the enjoyment even somewhat arbitrarily of privileges and facilities which Congress may not

36 "As a result of the complete power of Congress over foreign commerce, it necessarily follows that no individual has a vested right to trade with foreign nations which is so broad in character as to limit and restrict the power of Congress to determine what articles of merchandise may be imported into this country and the terms upon which a right to import may be exercised. This being true, it results that a statute which restrains the introduction of particular goods into the United States from considerations of public policy does not violate the due process clanse of the Constitution." Buttfield v. Stranahan, (1904) 192 U. S. 470,48 L. Ed. 525, 24 S. C. R. 349.

${ }^{37}$ Senator Knox made this statement during the course of the debatc in the Senate on the Beveridge bill. . Cong. Rec. vol. 41, p. 1879.

${ }_{38}$ Constitution of the United States, Art. I, Sec. 8. 
merely create but may also destroy; whereas he may claim a higher degree of protection for his right to engage in an interstate commerce which was not in the power of Congress to create but merely to "regulate." 39

The foregoing analysis presents what the writer regards as the more important arguments which have been used to prove that the Child Labor Law is not a regulation of commerce in the constitutional sense. A somewhat extended discussion of the point has seemed desirable, because it is without question the point which has been most hotly debated and which has seemed to the authorities on both sides of the case the most vital issue involved in the whole controversy.

2. It Violates the Tenth Amendment. - The Tenth Amendment reserves to the states or to the people all powers not delegated to the federal government nor prohibited to the states. It has been alleged that the federal Child Labor Law contravenes this amendment.

Now if the opponents of the law succeed in establishing their contention that the act is not a regulation of commerce, then it would seem to follow as a natter of course that Congress has passed a law which cannot be justified as an exercise of any delegated power, and such a law becomes ipso facto an invasion of the reserved rights of the states. The argument has not always been put, however, in this conservative form. More than one critic of the law has urged as a more or less separate objection to it that in its purpose and effect it invades the reserved rights of the states and therefore violates the spirit if not the letter of the Tenth Amendment. "It was conceded by all," declared ex-President Taft, "that only States could regulate child labor. . . Can any man fairly say that this was not an effort of Congress, by duress, to control the discretion of the

39 This distinction is emphasized with clearness by Bruce, op. cit., 3 Minnesota Law Review 96, and also by Willoughby, op. cit., Sec. 349. Both writers rely upon the statement of the court in Ex parte Jackson, (1877) 96 U. S. 727, 24 L. Ed. 877: "We do not think that Congress possesses the power to prevent the transportation in other ways, as merchandise, of matter which it excludes from the mails. To give efficiency to its regulations and to prevent rival postal systems, it may perhaps prohibit the carriage by others for hire, over postal routes, of articles which legitimately constitute mail matter, in the sense in which those terms were used when the Constitution was adopted, consisting of letters, and of newspapers and pamphlets when not sent as merchandise; but further than this its power of prohibition cannot extend." 
State intended by the Constitution to be free?" 40 Professor Willoughby regards it as "an attempt upon the part of the Federal Government to regulate a matter reserved to the control of the States." 41 The same view is most emphatically expressed by the Judiciary Committee of the House of Representatives in reporting upon the Beveridge bill. They said: "The lives, health, and property of the women and children engaged in labor are exclusively within the power of the States, originally and always belonging to the States, not surrendered by them to Congress. . . The assertion of such power by Congress would destroy every vestige of State authority, obliterate State lines, nullify the great work of the framers of the Constitution, and leave the State governments mere matters of form, devoid of power, and ought to more than satisfy the fondest dreams of those favoring centralization of power." 42

While courts have usually refrained from invalidating laws because of their alleged violation of the "spirit" of the constitutional prolibitions in cases where some doubt has existed as to the violation of the letter, attention is called to the fact that one of the important restrictions upon the power of the states and of the federal government to levy taxes has been grounded, not upon any specific clause of the constitution, but upon the essential nature of the federal union. This is the restriction upon the laying by either government of taxes upon the agencies, property, functions, or instrumentalities of the other. ${ }^{43}$ While this restriction has not rested upon any alleged violation of the Tenth Amendment, it has been argued that it would not be unreasonable for the Supreme Court to use it as authority by way of analogy for recognizing the existence of certain restrictions upon the exercise by Congress of its power to regulate commerce when by

40 Taft, op. cit., p. 273 , note 11 , supra.

41 Willoughby, op. cit., II, Sec. 348

42 Quoted by Watson, op. cit., pp. 532-534.

43 Willoughby, op. cit., I, Sec. 40. In The Collector v. Day, (187J) 11 Wall. (U.S.) 113, 20 L. Ed. 122. the court said: "It is admitted that there is no express provision in the Constitution that prohibits the general government from taxing the means and instrumentalities of the states, nor is there any prohibiting the states from taxing the means and instrumentalities of that government. In both cases the exemption re:ts upon necessary implication, and is upheld by the great law of self-preservation; as any government, whose means employed in conducting its operations, if subject to the control of another and distinct government, can exist only at the mercy of that government." See also Green, op. cit., I11. Law Bul. 13. 
such regulation the essential nature of the federal union in the matter of the distribution of powers is being threatened.

3. It Takes Liberty and Property Without Due Process.of Law. Even if it be granted, however, that the Child Labor Law is a regulation of commerce in the constitutional sense and that it is not a violation of the Tenth Amendment, it has still been the object of attack as an act which deprives persons of liberty and property without due process of law. It has already been made clear $^{44}$ that any exercise of a national police power must be kept within the limits of the specific restrictions of the Bill of Rights, perhaps the most important of which is the due process clause of the Fifth Amendment. ${ }^{45}$ The argument that the act is a violation of the guarantee of due process of law has taken two forms.

In the first place, it has been urged that "the right to liberty and property would certainly include the continuance of the right of interstate traffic in goods which were in themselves harmless and innocent." 46 No one can be said to enjoy a property right to ship commodities in interstate commerce when those commodities are harmful or when the shipment itself is an act of evil tendency. But any prohibition placed by Congress upon the right to ship harmless commodities destined for harmless uses constitutes an arbitrary invasion of a property right and is a denial of due process of law.

Now those who deny the validity of the Child Labor Law do not agree among themselves that there is a property right to ship goods in interstate commerce. ${ }^{47}$ But even assuming that no such right does exist, it is still urged that the law fails of due process. It is well established that any state may prohibit child labor without depriving any one of his constitutional rights; but it is equally well established that Congress cannot directly prohibit child labor under any power it tiow possesses. Now it is argued that even if the right to ship harmless goods in interstate commerce is one which Congress under the commerce clause might legitimately take away entirely, it would still be a denial of liberty or property without due process of law for Congress to make the continued enjoyment of the privileges of interstate commerce con-

\footnotetext{
443 Minnesota Law Review 299.

${ }^{45}$ Constitution of the United States, Amendment V.

${ }^{46}$ Bruce, op. cit.. 5 Mich. Law Rev, 636.

${ }^{47}$ See infra, p. 476.
} 
tingent upon abandoning a course of action which so far as any possible prohibition by Congress is concerned a person has a perfect right to pursue. In other words, Congress cannot withdraw a privilege which can be enjoyed only under its permission, for the purpose of making that withdrawal a punishment for doing something which Congress had no direct authority to forbid. Such an exercise of power by Congress rests upon the same principle as a state statute which, while not directly forbidding child labor, forbids those who employ children "to shave, to ride in an automobile, or to have children of their own." ${ }_{48}$ It is one thing to prohibit child labor directly; it is another and far different thing to permit the continuance of child labor only on the condition of the forfeiture of a right or privilege shared by all the other members of the community. In Western Union Telegraph Company v. Kansas ${ }^{49}$ the Supreme Court held that the plaintiff company had been denied due procéss of law by a statute which made its admission into the state as a foreign corporation-admission which it was granted the state was under no obligation whatever to allow-contingent upon payment by the company of taxes which the state was without constitutional authority to impose. There are other cases in which a similar principle has been applied. ${ }^{50}$ It is in the light of the authority of these cases and the reasoning set forth above that the Child Labor Law is believed to work a denial of due process of law.

4. The Majority Opinion of the Supreme Court. ${ }^{51}$ It is unnecessary to dwell at length upon the opinion of the majority of the Supreme Court which held the federal Child Labor Law invalid. That opinion was reasoned with a brevity that was entirely surprising considering the importance of the question involved. It does not allude in any way to the contention of the plaintiff that the act works a denial of due process of law. The decision rested upon two points : first, that the Child Labor Law is

48 Green, op. cit., Ill. Law Bul. 11. The most effective statement of this argument is found in Professor Green's article.

49 (1910) 216 U. S. 1, 54 L. Ed. 355, 30 S. C. R. 190.

50 Herndon v. Chicago, etc., Ry. Co., (1910) 218 U. S. 135, 54 L. Ed. 970, 30 S. C. R. 633; Harrison v. St. Louis, etc., R. Co., (1914) 232 U. S. 318, 58 L. Ed. 621,34 S. C. R. 333; New York Life Ins. Co. v. Head. (1914) 234 U. S. 149, 58 L. Ed. 332, 34 S. C. R. 879. These cases cited by Green, op. cit., Ill. Law Bul. 18.

51 Written by Mr. Justice Day and concurred in by Justices White, VanDevanter, Pitney, and McReynolds. 
not a regulation of commerce, second, that it violates the Tenth Amendment.

The first of these arguments proceeds along familiar lines. The power to "regulate" commerce is the power to "prescribe the rule by which commerce is to be governed," and does not include the right to "forbid commerce from moving and thus destroying it as to particular commodities." The cases in which Congress has prohibited interstate commerce in certain commodities have all rested "upon the character of the particular subjects dealt with and the fact that the scope of governmental authority, state or national, possessed over them is such that the authority to prohibit is as to them but the exertion of the power to regulate. . . . In each of these instances the use of interstate transportation was necessary to the accomplishment of harmful results." The Child Labor Law does not, however, regulate transportation, but aims to standardize child labor. The goods shipped are harmless and the fact that they may be intended for interstate commerce does not make them articles of that commerce at the time they were produced. There is no force in the argument that the law prevents unfair competition between states with child labor laws of different standards. So also there are many conditions which give certain states advantages over others, but Congress has no power to regulate local trade and commerce for such a purpose.

The act violates the Tenth Amendment. "The grant of authority over a purely federal matter was not intended to destroy the local power always existing and carefully reserved to the states in the Tenth Amendment to the Constitution." Under the law Congress "exerts a power as to purely local matters to which the federal authority does not extend. The far reaching result of upholding the act cannot be more plainly indicated than by pointing out that if Congress can thus regulate matters entrusted to local authority by prohibition of the movement of commodities in interstate commerce, all freedom of commerce will be at an end, and the power of the states over local matters may be elimi-. nated, and thus our system of government be practically destroyed."

The Argument for the Constitutionality of the Law

The constitutionality of the Child Labor Law has probably been discussed more trequently and at greater length by its 
friends than by its enemies. ${ }^{52}$ An analysis of the arguments in support of the law indicates that they clash squarely at all vital points with the arguments which have just been sêt forth. They may, therefore, be grouped under the same three headings.

1. It Is a Regulation of Commerce in the Constitutional Sense. The friends of the Child Labor Law have bent their efforts with special care to proving that it is a regulation of commerce in the constitutional sense, a task which has of course involved disproving the arguments of their opponents that the law is not such a regulation. This task has been approached in a wide variety of ways and from many different points of view. The writer believes, however, that these arguments may all be subsumed under three major propositions, which if established would prove the point at issue. These will be treated in order.

(a) The Pozver to Regulate Interstate Commerce Includes the Power to Prohibit Entirely Shipment in Such Commerce of Specified Persons and Property: In the first place, the power to prohibit is not incompatible with the power to regulate commerce. Even if it is true that "the power to regulate implies the existence of the thing regulated," 53 it is equally true that "the power to prescribe the rule by which commerce is carried on does not negative the power to prescribe that certain-commerce shall not be carried on."." As Mr. Justice Holmes puts it, "Regulation

52 Before the Supreme Court annulled the law, the following discussions had appeared supporting its constitutionality: Goodnow, Social Reform and the Constitution, (1911) 80; MacChesney, Constitutionality of a Federal Child Labor Law, (1915) The Child Labor Bul. IV, p. 155; Parkinson, Brief for the Keating-Owen Bill, (1916) The Child Labor Bul., IV, pt. 2, p. 219; Constitutional Prohibitions of Interstate Commerce, (1916) 16 Col. Law Rev. 367; The Federal Child Labor Law, (1916) 31 Pol. Sci. Quar. 531; Precedents for Federal Child Labor Legislation, (1915) The Child Labor Bul., IV, p. 72; Troutman, Constitutionality of a Federal Child Labor Law, (1914) 26 Green Bag 154; see also note, The Use of the Power over Interstate Commerce for Police Purposes, (1917) 30 Harv. Law Rev. 491. Since the decision in Hammer v. Dagenhart, supra, the opinion of the majority has been criticized in the following articles: Gordon, The Child Labor Law Case, (1918) 32 Harv. Law Rev. 45; Jones, The Child Labor Decision, (1918) 6 Cal. Law Rev. 395; Parkinson. The Federal Child Labor Decision, (1918) The Child Labor Bul., (1918) VII, p. 89; Powell, The Child Labor Decision. (1918) The Nation, vol. 107, p. 730; The Child Labor Law, the Tenth Amendment and the Commerce Clause, (1918) 3 So. Law Quar. 175; see also note, (1918) 27 Yale Law Jour. 1092, and (1918) 17 Mich. Law Rev. 83.

53 Note 15 , supra.

54 Powell, op. cit., So. Law Quar. 
means the prohibition of something, and when interstate commerce is the matter to be regulated I cannot doubt that the regulation may prohibit any part of such commerce that Congress sees fit to forbid." ${ }^{55}$

In the second place, there is evidence to indicate that the framers of the constitution intended the power given to Congress to regulate interstate commerce to include the power to prohibit such commerce in certain cases. This is shown, first, by the fact that they intended to give Congress all the power over interstate commerce that the states had previously had and this included the power to prohibit such commerce. ${ }^{56}$ It is shown, secondly, that they specifically denied to Congress the right to pass any law prior to 1808 which should prohibit the "migration or importation" of slaves, ${ }^{57}$ a denial of power entirely superfluous unless the power to prohibit such commerce existed, in the absence of such denial.

In the third place, the power to regulate foreign commerce has always been held to include the power to place prohibitions upon such commerce, ${ }^{58}$ and the commerce clause gives to Congress the same power over interstate as over foreign commerce. The friends of the Child Labor Law do not infer from this that Congress could necessarily impose the same restrictions upon interstate commerce as upon foreign commerce; but they assert that whatever difference there may be exists not because the power exercised is the power to regulate in the one case but not in the other, but because the limitations of due process of law affect the power to regulate in different ways. In other words, although the constitutional restrictions on that power may vary with the kind of commerce, the power to "regulate" remains the same. And since the power to regulate foreign commerce includes the power to prohibit it, it must of necessity follow that the power to regulate interstate commerce also includes the power to impose prohibitions upon it.

Finally, it is only necessary to refer to the Lottery Act, the White Slave Act, and the Pure Food Act to show that there have

55 Hammer v, Dagenhart, note 9, supra.

${ }^{56}$ This argument is carefully developed by Mr. Parkinson, op. cit., Col. Law Rev. 370 et seq.

57 The Constitution of the United States, Art. I, Sec. 9.

${ }^{58}$ For citation of cases in support of this view see Parkinson, op. cit., The Child Labor Bul. 225-228; also note by E. B. Whitney, (1898) 7 Yale Law Jour. 291. 
been other cases in which the Supreme Court has viewed with approval the exercise by Congress of the power to prohibit entirely interstate commerce in certain commodities.

(b) The Powier to Regulate Interstate Commerce May $\mathrm{Bc}$ Used for the Protection of Public Health, Morals, Safety, and Welfare in General: This point might perhaps be stated in this way: a regulation of commerce does not cease to be such merely because its purpose and effect are to eradicate evils over which Congress has no direct control. It is not the business of the Supreme Court to pry into the motives which prompt Congress to exercise its power to regulate commerce. Whatever restrictions there may be upon the power by reason of alleged violations of due process of law, the power to regulate commerce may properly be used by Congress to remedy any evils which may exist before, during, or after interstate commerce takes place, without making such action any less truly an exercise of the power to regulate such commerce. It is apparent that this view is in conflict with the position of the opponents of the Child Labor Law who argue that, while Congress may exercise a real police power under the commerce clause, that police power is limited to the actual domain of interstate commerce and may only extend to the prohibition of evils existing in or directly promoted by such commerce. The friends of the law, in short, look upon interstate commerce as a means entrusted to Congress to be used in any manner which will promote the public health, morals, and safety; and they find in the Lottery Act, the White Slave Act, and laws of similar character instances in which Congress has used the commerce power, not to protect any particular group of people, not to strike at evils which are limited to any particular locality, but to protect the nation at large from injury or danger. The evils, in other words, do not need to have any particular locus to be within the reach of congressional police power under the conmerce clause.

(c) No Distinctions Exist Between This Law and the Other Police Regulations Based on the Commerce Clause That Would Make It Less a Regulation of Commerce Than They: Those who believe the Child Labor Law to be constitutional feel that th: efforts to distinguish it from the Lottery Act and so forth and to prove that, while those earlier acts were bona fide regulations of commerce, the Child Labor Law is not, are after all merely efforts to set up straw men for the purpose of knocking them down. 
They take the position, first, that the alleged distinctions do not in fact exist; and, second, that if they did exist they would not prove the Child Labor Law to be any less a regulation of commerce than the earlier statutes mentioned.

In support of the first point it is contended that the Child Labor Law does not stand alone in excluding from interstate commerce articles in themselves harmless. Lottery tickets are no more harmful in themselves than milk tickets; the goods excluded by the Commodities Clause $^{59}$ are in all respects above reproach; the anti-trust statutes forbid the shipment of goods intrinsically indistinguishable from any other articles of commerce. Nor is it true that the Child Labor Law is unique in that it excludes goods when no danger or injury can result from their interstate transportation. The other police regulations passed by Congress under the commerce clause have rested usually on the ground that the forbidden shipments were "acts of evil tendency." So also is the shipment of goods manufactured in a child labor factory an act of evil tendency. It promotes child labor both before and after the actual shipment takes place: before, because a producer could not afford to continue the employment of children if it cut him off from interstate markets; after, because states which may honestly desire to abolish child labor feel a reluctance to place their own industries at the mercy of the competition which results from the shipping in from other states of goods made by children. It is a peculiarly naive logic which insists that a cause must always chronologically precede an effect, and that interstate commerce cannot cause or promote child labor because the immediate child labor is over before the immediate goods are delivered to the interstate carrier. The manufacture of goods is a continuous process, and its effects control its beginnings quite as much as with lottery tickets. This point has been clearly put in language which is worthy of quotation: "Clearly enough the transportation is a contributing factor to the employment of children, as it is to the consumption of liquor and the purchase of lottery tickets. In terms of physics, the transportation is a pull in the one case, and a push in the others. The matter belongs, however, to the realm, not of physics, but of economics. And in economics the push and the pull are not to be differentiated. In so far, then, as the majority [of the Supreme Court] imply

59 See note 71, (1919) 3 Minsesota Law Review 311. 
that the interstate transportation was not necessary to the harmful results aimed at by the Child Labor Law, they are obviously in error. Unless it were necessary, the law would have been idle and useless, no employer or 'next friend' of children would have objected to it, and it would not have touched, even obliquely, matters reserved to the states." ${ }^{60}$ In other words, just as the Mann Act forbids the use of interstate commerce as a facility in carrying on the white slave traffic, so the Child Labor Law prohibits such commerce from being used to promote the evil of child labor, and there is, accordingly, no difference in principle between the two as to their being each a bona fide regulation of interstate commerce.

But in the second place, even if it be admitted that there are important distinctions between the Child Labor Law and the other regulations enacted under the commerce clause, those differences do not have any bearing whatever upon the question whether the Child Labor Law is or is not a regulation of commerce. The distinction, for example, that the Child Labor Law benefits the producer, while the Lottery Act and similar statutes protect the consumer, is an entirely artificial and worthless distinction. The enemies of the law are challenged to show anything in the commerce clause itself, the acts of Congress passed in pursuance thereof, and the decisions of the United States Supreme Court, which in any way suggest that a prohibition of interstate commerce loses its character as a regulation of that commerce in the constitutional sense because it is the consumer of goods shipped, rather than the producer, who receives the benefit therefrom. To hold otherwise is to inject into the constitution something which the framers did not put there. "Proponents [of this distinction] are standing on their political ideas of what ought to be in the Constitution rather than on what the Supreme Court has said is there." ${ }^{\prime 1}$ In like manner, even if it is admitted for the sake of argument that the Child Labor Law excludes harmless commodities from interstate commerce, or even admitting that the exclusion established is arbitrary and unreasonable, this would not prove that the law is not a regulation of commerce. It would merely prove that Congress had regulated commerce in such a way as to deprive persons of

60 Powell, op. cit., So. Law Quar. 197.

${ }_{61}$ Parkinson, op. cit., 31 Pol. Sci. Quar. 537. 
liberty or property without due process of law. 'In the Lottery Case and in Clark Distilling Co. v. Western Maryland Ry. Co. ${ }^{62}$ the Supreme Court plainly intimated that power to exclude commodities from interstate commerce might be held to be limited so as to preclude its exercise in a manner palpably arbitrary, but in each of these cases the implication is very plain that any. such limitation would arise from the due process of law clause and not at all from any implied narrowing of the meaning of the word "regulate" as used in the commerce clause. What the critics of the law have done in using the distinctions mentioned to prove that the Child Labor Law is not a regulation of commerce is to employ an argument "built upon a due process distinction and then unwarrantably transferred to the commerce clause." ${ }^{63}$

2. The Child Labor Law Does Not Work a Denial of Duc Process of Law. When Senator Beveridge was defending the constitutionality of his child labor bill in 1906 he took the position that the power of Congress over interstate commerce was absolute, and that while Congress would naturally be restrained by considerations of policy and expediency from any arbitrary and unreasonable exercise of that power, the power itself was subject to no constitutional restrictions of any kind. ${ }^{64}$ This means, of course, that Congress in the exercise of its commerce power is not restricted by any limitations arising from the due process of law clause of the Fifth Amendment.

A writer on the subject who regards the law as unconstitutional upon other grounds takes the position that there is no property right to ship products in interstate commerce. That even if there were such a right it would be a "right to engage in interstate commerce lawfully regulated. So, if the regulation be lawful, the property right has existed subject to the regulation. And to assail the validity of the regulation by the due process clause is to argue in a circle." ${ }_{65}$

62 (1917) 242 U. S. 311, 61 L. Ed. 326, 37 S. C. R. 180.

${ }^{63}$ Powell, op. cit., 3 So. Law Quar. 194.

${ }^{64}$ In the course of the debate the senator said: "Will you ask me whether or not I think we have power to prohibit the transportation in interstate commerce of the milk of a cow milked by a young lady eighteen years old? Undoubtedly we have the power, but undoubtedly we would not do it. We have the power to prohibit the transportation through interstate commerce of any article." Cong. Rec., vol. 41, p. 1826.

65 Hull, op. cit., 31 Pol. Sci. Quar. 529. 
With these two exceptions, there would seem to be no disagreement among friends and critics of the Child Labor Law that the validity of any congressional prohibitions of interstate commerce must be subject to due process of law; and this view is supported by decisions of the Supreme Court. ${ }^{66}$ The proponents of the law, however, deny that it deprives any person of property or liberty without due process of law and they advance the following arguments in support of their view.

At the outset attention is called to the fact that "the due process does not protect things, but persons. Goods made by child labor have no constitutional immunities." 67 Therefore the law does not fail of due process merely because the goods shipped are harmless.

Compliance with the test of due process does not depend, therefore, upon the character of the goods excluded but upon the effect of that exclusion upon the rights and immunities of those who are forbidden to ship the goods. Now a constitutional right to ship in interstate commerce the products of factories employing children must of necessity rest upon a constitutional right to employ children; just as the constitutional right to ship lottery tickets in interstate commerce depends upon the existence of a constitutional right to conduct or engage in a lottery enterprise. The question then reduces itself to this: is there a right to employ children, of such a nature that an interference with it constitutes a denial of due proces of law? Now the tests of due process of law are not very definite, and the cases in which acts of Congress have been invalidated for violation of the due process clause of the Fifth Amendment are relatively rare and throw little or no light on this particular problem. However, it has been held that the requirement of due process of law imposed on the federal government by the Fifth Amendment is the same in principle as the requirement of due process of law imposed upon the states by the Fourteenth Amendment. ${ }^{68}$ And since it has long been established not only by the state courts $^{69}$

66 As, for instance, in Adair v. United States, note 26, supra. See also 3 Minnesota Law Review 299.

67 Powell, op. cit., 3 So. Law Quar. 194.

68 Parkinson, op. cit., The Child Labor Bul. v. IV, pt. 2, p. 245, citing Slaughter House Cases, (1872) 16 Wall. (U.S.) 26, 19 L. Ed. 915: Tonawanda v. Lyon, (1901) 181 U. S. 389, 45 L. Ed. 908,21 S. C. R. 609 ; Twining v. New Jersey, (1908) 211 U. S. 78, 53 L. Ed. 97, 29 S. C. R. 14. ${ }^{69}$ See 16 R. C. L. 477 and cases cited. 
but also by the Supreme Court $^{70}$ that a state may forbid or regulate the employment of children without depriving anyone of liberty or property without due process of law, it must follow that Congress does not violate due process by interfering in a similar or analogous manner with the employment of children.

It does not, however, follow from this argument that Congress can deny the privileges of interstate commerce to one who pursues any line of conduct that the state can interfere with without a violation on its part of due process of law. "So Congress could not prescribe that a man should not ship goods across a state line in case he violated his marriage vows. There would be no nexus between the infidelity and the transportation. But there is a nexus between making goods and shipping them. Evil in the making grows by the transportation it feeds on. Transportation increases child labor. It aids an evil which is a menace to the attainment of national objects. Congress cannot obliterate the evil. But it should be allowed to lessen it by denying it aid from the enjoyment of the highways under national control. If it ever should go further and seek to apply its commerce power to evils in no way dependent upon the commerce subject to its control, then the Supreme Court may with wisdom declare that it has failed to make a legitimate connection between its prohibition of transportation and the circumstances on which the prohibition is conditioned. But the court did not need to annul the Child Labor Law in order be free to deal with such cases if ever they should arise." 71

3. It Does Not Violate the Tenth Amendment. Those who defend the Child Labor Law regard the contention that the law violates the Tenth Amendment with less respect than any of the other arguments directed against its constitutionality. They point out three weaknesses in it which convince them of its lack of merit. In the first place, the Child Labor Law takes away from the states no right reserved to them by the constitution. The law forbids the shipment of certain commodities across state lines; it does not forbid the employment of children. No state at any time during its history has ever had the power to compel any other state to admit its products; and during the Confederation the states freely exercised the power to set up embargoes

io Sturges \& Burn Mfg. Co. v. Beauchamp, (1913) 231 U. S. 320,58 L. Ed. 245,34 S. C. R. 60.

${ }^{71}$ Powell, op. cit., 3 So. Law Quar. 201. 
and restrictions on goods from neighboring states. Therefore when the Child Labor Law takes from the individual states the right to impose the products of their industry upon other states through the channels of interstate commerce it takes away no right which the states ever had and therefore no right which could have been reserved to them by the federal constitution.

In the second place, it is held that it is unsound to declare the law void as an invasion of the reserved powers of the states because of its indirect or incidental effects. Never before has the exercise by Congress of an admitted power been held unconstitutional because of such incidental effects upon the authority of the states. Although there have been plenty of instances in which congressional authority over interstate commerce has been so exercised as to impair seriously the freedom of action of the states in matters within their jurisdiction, these have always been regarded as the inevitable results of our federal form of government. $^{72}$ Thus the Lottery Act, the Pure Food Act, the Meat Inspection Act, all in precisely the same way discourage the production of the commodities excluded from interstate commerce. To invalidate one law because of its indirect invasion of the power of the states and not to treat in the same way other acts which also invade that power leaves upon the shoulders of the court the burden of determining when the indirect effects of a law are a sufficiently serious interference with state authority to warrant the interposition of the judicial ban; and we have thus opened up another fertile field for the production of judgemade law.

Finally, the argument based on the Tenth Amendment is superfluous. "If the Child Labor Law was a proper exercise of power to regulate interstate commerce, it was by the explicit terms of the Tenth Amendment not an exercise of a power reserved to the states. If it was not a proper exercise of the power to regulate interstate commerce, it was unconstitutional. and nothing more need be said about it." "3

72 An extreme example of this is the "Shreveport Case," Houston, etc., Ry. Co. v. United States, (1914) 234 U. S. 342, 58 L. Ed. 1341. 34 S. C. R. 833, in which railroads were compelled to raise their intrastate freight rates which had been fixed by a state railroad commission, because those rates produced discrimination against competing shipments in interstate commerce which were being made at rates held reasonable by the Interstate Commerce Commission.

${ }^{73}$ Powell, op. cit., So. Law Quar. 
4. The Dissenting Opinion of Mr. Justice Holmes. ${ }^{74}$ The dissenting opinion of Mr. Justice Holmes is not an attempt to build up a constructive argument in support of the Child Labor Law, but is rather a pungent criticism of the reasoning of the majority. Since the majority opinion did not take up at all the due process of law argument, the justice confined the batteries of his criticism in general to a single concise attack upon the remaining two points of difference.

He protests most vigorously against invalidating an exercise by Congress of one of its admitted powers because of the collateral effect of such regulation upon matters reserved to state control. "I should have thought," declared the justice, "that the most conspicuous decisions of this court had made it clear that the power to regulate commerce and other constitutional powers could not be cut down or qualified by the fact that it might interfere with the carrying out of the domestic policy of any state." He then proceeds to comment on some of these "conspicuous decisions" in which the indirect effect upon state authority of congressional acts has been held quite irrelevant to the question of their validity. Furthermore, some of the acts already sustained have excluded from commerce commodities intrinsically harmless, and the Supreme Court in the Hoke case ${ }^{75}$ has specifically put itself on record as upholding the use of the commerce power for police purposes. In these cases "it does not matter whether the supposed evil precedes or follows the transportation. It is enough that in the opinion of Congress the transportation encourages the evil.", 76

It is no longer open to dispute that the power to regulate commerce includes the power to prohibit it in some cases. $\mathrm{Mr}$. Justice Holmes denies strenuously the propriety of upholding or invalidating the exercise of this power to prohibit commerce in accordance with judicial views of the morality or immorality of the transactions prohibited. But if this were permissible, there is no denying that child labor is an evil which ought to be dealt with as readily as any other. "I should have thought that if we were to introduce our own moral conceptions where in my opinion they do not belong, this was pre-eminently a case for upholding the exercise of all its powers by the United States."

74 Justices Brandeis, McKenna, and Clark concurred in the dissent.

75 Note 31 , supra.

i6 Mr. Justice Holmes, dissenting opinion, 247 U. S. at p. 279. 
And finally, the law does not interfere with any power reserved to the states. "They may regulate their internal affairs and their domestic commerce as they like. But when they seek to send their products across the state line they are no longer within their rights. . . . The public policy of the United States is shaped with a view to the benefit of the nation as a whole. . . The national welfare as understood by Congress may require a different attitude within its sphere from that of some self-seeking state. It seems to me entirely constitutional for Congress to enforce its understanding by all the means at its command."

\section{Conclusion}

In the foregoing analysis of the arguments for and against the constitutionality of the Child Labor Law, the effort has been to make clear the exact issues involved in that controversy. It should also make clear that the advocates and opponents of the law disagreed not only upon the question of its validity but also upon the question of just what the actual result would be of a decision sustaining the law. Clearly it would advance the national police power far beyond its old limits. To what extent would it be expanded? Would there be any real limits upon that expansion?

The opponents of the law have felt that to uphold its constitutionality would be to open wide the door to congressional interference in any and every matter now confided to state control. In fact, they have pretty unanimously been seized with an irresistible impulse to lapse into reductio ad absurdum and paint in the most lurid colors the constitutional havoc wrought upon state authority and state institutions by such a doctrine. They argue that, if a man can be denied the privileges of interstate commerce because he employs children, he can be denied those privileges because of any other line of conduct which a majority in Congress view with disapproval; the line which now exists between the police power of the state and the regulatory power of Congress would be obliterated, and the only difference between the authority of the two governments to regulate the conduct of its citizens would be that one could act directly and the other by a process of indirection. 
It seems clear that some at least who have taken this extreme view of the results of the Child Labor Law in expanding the scope of the national police power have lost sight of the fact that any exercise of that power must be kept within due process of law. But, even if this were not the case, it should be borne in mind that a court which has expressed its contempt for those who show a tendency to push the application of constitutional principles to a "drily logical extreme" is not apt to permit itself to be browbeaten by the requirements of absolute consistency into upholding any law which is a manifestly ridiculous or dangerous application of even the most harmless principle.

But if the Supreme Court had been willing to sustain the Child Labor Law on the basis of the argument advanced by its friends in its behalf, it is apparent that, while the national police power would have been strikingly enlarged, that expansion would not have been unlimited but would have been confined to well defined boundaries. Under this interpretation, the power of Congress to exclude commodities from the channels of interstate commerce could be used, not to strike at any evil which Congress might succeed by this method in bringing within its reach, but to strike at only those evils which could be said to be promoted by interstate commerce or motivated by the expectation or necessity of enjoying the privileges of such commerce. Concretely, those evils would be those connected with the processes of manufacturing the products destined for interstate markets. Congress would doubtless have gained the authority to regulate the conditions of labor in any industry dependent on interstate commerce for its markets, and this of course includes every industry of importance in the country; it is not clear that it would have gained much more.

But if the scope of the national police power under the commerce clause was not enlarged by the decision invalidating the Child Labor Law, neither was it narrowed. Congress still retains full authority to deal with any evil which threatens to injure, destroy, or obstruct interstate commerce. There still remains the authority to protect the national health, morals, safety, and general welfare from such evils as depend upon the physical agency of interstate commerce facilities for the transportation of commodities or persons. But evils which feed on interstate commerce only in the sense that they would dwindle 
away if the right of those responsible for them to engage in interstate commerce were withdrawn are still beyond the reach of congressional power as conferred by the commerce clause. Congress may exercise a police power to protect interstate commerce, and to protect the nation from the actual misuse of that commerce; it may not, however, protect the nation from all the other equally dangerous and much more numerous evils which would die of discouragement if the interstate commerce they thrive on were prohibited. 



\section{THE NATIONAL POLICE POWER UNDER THE TAX- ING CLAUSE OF THE CONSTITUTION*}

When the United States Supreme Court decided in the summer of 1918 that the Keating-Owen Act, ${ }^{1}$ closing the channels of interstate commerce to the products of mines and factories employing child labor, was an attempt by Congress to exercise a power not confided to it by the constitution and was therefore null and void, ${ }^{2}$ the child labor exterminators, in Congress and out, apparently undismayed, girt up their loins and sallied forth on what one of them aptly termed "a quest of constitutionality."3 There seemed to be no thought that Congress should abandon its efforts to prohibit child labor; the problem merely resolved itself into one of method. One method had failed and another must be found. ${ }^{4}$ Accordingly a rather astonishing variety of proposals was brought forward in the hope that an effective and at the same time constitutional federal child labor law might be evolved. Three resolutions were introduced proposing a child labor amendment to the national constitution. ${ }^{5}$ Senator Owen demanded the reenactment of the Keating-Owen Act with an added provision that no judge should have the power to declare it unconstitutional. $^{6}$ Also a bill embodying the principle of the Webb-

*This article, though complete in itself, is a development of the topic of National Police Power under the Commerce Clause, 3 Minnesora LAw REviEW 289, 381, 452.

1 Att of September 1, 1916, Chap. 432, 39 Stat. at L. 675.

2 Hammer v. Dagenhart, (1918) 247 U. S. 251, 62 L. Ed. 1101, 38 S.

C. R. 529 .

${ }^{3}$ Title of an article by Raymond G. Fuller, in Child Labor Bulletin, Nov., 1918, Vol. 7, 207.

4 Senator Lodge declared in the Senate debate on the Child Labor Tax (see infra note 10), "The main purpose is to put a stop to what seems to be a very great evil and one that ought to be in some way put a stop to. If we are unable to reach it constitutionally in any other way, then I am willing to reach it by the taxing power, which the courts have held can be used constitutionally for such a purpose. I see no other way to do it." Cong. Rec., Dec. 18, 1918, Vol. 57, 611.

5 House Joint Resolution 300, introduced by Mr. Mason (Ill.), Cong. Rec., June 11, 1918, Vol. 56, 7652; House Joint Resolution 302, Mr. Rogers (Mass.), ibid, 7776; House Joint Resolutions 304, Mr. Fall (Pa.), ibid, 7776.

B Cong. Rec. June 6, 1918, Vol. 56, 7418, Sen. bill 4671. Debated June 6. 1918, ibid, 7431, 7435 . 
Kenyon Act was introduced, forbidding the shipment of the products of child labor into states which prohibit the employment of children. ${ }^{7}$ Again it was proposed that the use of the mails be denied to the employers of children. ${ }^{8}$ Still another bill relied upon the war power as a basis for a flat prohibition of child labor by declaring such a prohibition necessary for "conserving the man power of the nation and thereby more effectually providing for the national security and defense." 9 Finally, proposals were made to drive child labor out of existence by use of the federal power of taxation; and when the Revenue Act of February 24, 1919, was passed, it contained provisions placing an excise tax of ten per cent upon the net profits of mining and manufacturing establishments employing children. ${ }^{10}$

Within three months of the enactment of this law it was declared unconstitutional by a federal district judge in North Carolina on the ground that it was an invasion of the domain of

7 Sen. bill 4762 , June 27, 1918, by Mr. Pomerene. Referred to Committee on Interstate Commerce. Cong. Rec., Vol. 56, 8341. See comments in Survey, June 15, 1918, p. 324.

8 Sen. bills 4732,4760 , June 27, 1918, by Mr. Kenyon. Referred to Committee on P. O. and P. Roads. Cong. Rec., Vol. 56, 8341 .

${ }^{2}$ House bill 12767, Aug. 15, 1918, by Mr. Keating (Col.), Cong. Rec., Vol. 56, 9238. Text of this bill is reprinted in Child Labor Bulletin, Aug., 1918, Vol. 7, 98.

${ }_{10}$ On June 27, 1918, Mr. Pomerene introduced a bill to tax the employment of children (S. R. 4763) which was referred to Committee on Interstate Commerce, Cong. Rec., Vol. 56, 8341. On. Nov. 15, 1918, he introduced a similar measure drafted in collaboration with Senators Kenyon and Lenroot as an amendment to the general revenue bill (H. R. 12863). This amendment was finally enacted.

The pertinent part of the act as passed is the first section, Act of Feb. 24, 1919, 40 Stat. at L. 1138. It reads as follows: "Every person (other than a bona fide boys' or girls' canning club recógnized by the Agricultural Department of a State and of the United States) operating (a) any mine or quarry situated in the United States in which children under the age of sixteen years have been employed or permitted to work during any portion of the taxable year; or (b) any mill, cannery, workshop, factory, or manufacturing establishment situated in the United States in which children under the age of fourteen years have been employed or permitted to work, or children between the ages of fourteen and sixteen have been employed or permitted to work more than eight hours in any day or more than six days in any week, or after the hour of seven o'clock post meridian, or before the hour of six o'clock ante meridian, during any portion of the taxable year, shall pay for each taxable year, in addition to all other taxes imposed by law, an excise tax equivalent to 10 per centum of the entire net profits received or accrued for such year from the sale or disposition of the product of such mine, quarry, mill, cannery, workshop, factory or manufacturing establishment."

Other proposals for destroying child labor by taxation were made in Congress. Two bills (H. R. 12705, 13087) introduced by Mr. Green (Ia.) and $\mathrm{Mr}$. Gard (Ohio) provided for the taxation of articles of interstate commerce in the manufacture of which child labor is employed. Cong. Rec., Vol. 56, 9051, 11310. It was proposed by Mr. Mason (III.) to levy 
state authority. ${ }^{11}$ At the time of the writing of this article an appeal from this decision is pending before the Supreme Court of the United States.

It would seem that in no case could the question be more squarely raised whether there are any constitutional limitations upon the purposes for which Congress may use its power to tax. The friends of this law do not claim that it was designed for the purpose of raising revenue, or for any other purpose than the destruction of child labor. ${ }^{12}$ If it should be held that this is a constitutional use of the taxing power it follows that there is stored up in the power to tax a most substantial fund of congressional authority to deal with social and economic problems, a police power more comprehensive and far-reaching in scope than can be derived from any other grant of power to Congress. ${ }^{13}$ It is the purpose of this article to examine the nature of such national police, power as may be derived from the power to tax and to determine what are the limitations, if there be any, to which that power is subject.

\section{The Clause Granting the Power to Tax}

Congressional authority to tax is granted in the following words of the federal constitution: "The Congress shall have Power (1) To lay and collect Taxes, Duties, Imposts and Excises, to pay the Debts and provide for the common Defense and general Welfare of the United States."14 For what seems at first glance to be a perfectly straightforward and unambiguous statement, this brief sentence has given rise to a surprising number of constitutional controversies of the very first magnitude. These disputes have related to two entirely separate

a tax of two dollars per day on all who employ chlidren. Cong. Rec., Vol. 56, Appendix, 461.

${ }_{11}$ May 2, 1919. The decision was handed down by Judge James $E$. Boyd, who rendered the district court decision in Dagenhart v. Hammer, invalidating the Keating-Owen Act. No opinion was written and the facts set forth above are based on press reports. See New York Times, May 2, 1919.

12 With the possible exception of its author, Senator Pomerene, who insisted that the purpose of its enactment was two-fold, to raise revenue and to destroy child labor. He expressed the belief that it would produce some revenue. Cong. Rec., Dec. 18, 1918, Vol. 57, 613.

${ }^{13}$ See articles by the writer on National Police Power under the Commerce Clause of the Constitution, (1919) 3 Mrnsesota Law Review, 289, 381, 452; Judge Charles M. Hough, Covert Legislation and the Constitution, (1917) 30 Harvard Law Rev. 801; Paul Fuller, Is There a National Police Power? (1904) 4 Col. Law Rev. 563.

14 Art. I, sec. 8, cl. 1. 
aspects of the taxing power. ${ }^{15}$ In the first place, there has been bitter disagreement as to the purposes for which. Congress is authorized to raise revenue. In other words, what may Congress legitimately do with the money raised by taxation? In respect to this question, which is not the one under consideration, we may merely note in passing that the following principles are now settled: First, the clause, "to pay the debts and provide for the common defense and general welfare of the United States," is not a separate grant of general legislative power, but is a statement of limitation indicating the purposes for which Congress may use the power to "lay and collect taxes, duties, imposts and excises." In short, Congress may lay and collect taxes in order to pay the debts and provide for the common defense and general welfare. ${ }^{16}$ Second, Congress is not limited in the purposes for which it may. spend money raised by taxation to such purposes as are covered by the legislative powers delegated to Congress by the constitution. It may spend money not only to aid in the exercise of those delegated powers, but also for the more comprehensive and general objects of "providing for the common defense and general welfare." ${ }_{17}$

15 Story, Commentaries on the Constitution, I, Sec. 958.

16 No one has expressed this more clearly than Jefferson in his opinion on the power of Congress to establish the Bank of the United States: "To lay taxes to provide for the general welfare of the United States, that is to say, 'to levy taxes for the purpose of providing for the general welfare.' For the laying of taxes is the power, and the general welfare the purpose, for which the power is to be exercised. Congress are not to lay taxes ad libitum, for any purpose they please; but only to pay the debts, or provide for the welfare of the Union. In like manner they are not to do anything they please to provide for the general welfare, but only to lay taxes for that purpose. To consider the latter phrase, not as describing the purpose of the first, but as giving a distinct and independent power to do any act they please, which might be for the good of the Union, would render all the preceding and subsequent enumerations of power completely “useless" Jefferson's Gorrespondence, Vol. 4; 524, 525. On the same point see Story, op. cit.. Secs. 907-930; Miller on the Constitution, 229: Hare American Constitutional Law, I, 241; Watson, Constitution. I, 390; Black. Constitutional Law, 207; Tucker, Constitution, I, 470; Federalist, No. 41.

Compare the opposite view of Chancellor Kent: "At present it will be sufficient to observe, generally, that Congress are authorized to provide for the common defense and general welfare; and for that purpose, among other express grants, they are authorized to lay and collect taxes, etc. . . Commentaries, 13th Ed., I, 259.

17 The classic argument in support of this position is. that of President Monroe in his message accompanying his veto of the Cumberland Road Bill. Richardson: Messages and Papers of the Presidents, II, 164-167; Hamilton's Report on Manufactures, Dec. 5. 1791. Works, Lodge Ed., Vol. 4. 151. See also Story, op. cit. Secs. 975-991; Willoughby, op. cit., I, 588. For opposite view see Tucker, op. cit., I, 475. 
The second group of controversies over the meaning of the taxing clause of the constitution has dealt, not with the question of the purposes for which revenue may legitimately be raised by taxation, but with the question whether or not Congress may use the power to tax for purposes which do not include the raising of any revenue at all, or include it only incidentally. For instance, may Congress tax solely in order to promote industry, or to drive out of existence practices or commodities injurious to the national welfare? It is clear that the scope and nature of any police power which Congress may enjoy under the taxing clause will depend upon the extent to which it may use its power to tax for purposes other than revenue.

The question of the puirposes for which Congress may use the power to tax has been answered with different degrees of conservatism. On the one hand are those who believe that this power may be legitimately used only for the raising of revenue. Midway, a more numerous group has urged that Congress may properly tax for revenue and in addition to accomplish or promote any other legislative object within the enumerated powers of Congress. Finally, the friends of the new child labor tax and measures like it allege that Congress may levy taxes for the purpose of regulating or controlling indirectly problems clearly outside of its delegated legislative authority, provided that such taxation has for its object providing for the common defense and general welfare of the nation. An examination of the merits of these three views in the light of the arguments advanced in their support will help materially in determining whether or not there is a national police power properly deducible from the congressional power to tax; and if there is such a police power, what, if any, are its.limits.

\section{Taxation for Revenue Only}

The proposition that Congress may use its grant of taxing power only to raise revenue is ancient and familiar doctrine. It has served as an argument for over a hundred years to those who have denied the constitutionality of the protective tariff. ${ }^{18}$ To that end it was vigorously urged by Calhoun and his South

18 For analysis of arguments for and against the constitutionality of protective tariffs, see passim Stanwood. Tariff Controversies in the United States in the Nineteenth Century. See also arguments on this point in Elliott's Debates, Vol. IV. Of course this is not the only argument urged against the validity of such tariffs. 
Carolina adherents in 1829 during the critical period of the nullification controversy; ${ }^{19}$ and it stood as a solemn pronunciamento in the party platform on which President Wilson was elected in 1912. ${ }^{20}$

It must not be assumed, however, that this view of the federal taxing power is the sole property of the free trader. It is not even incompatible with a belief in the constitutional propriety of protection. Nor does it place one in the position of maintaining with an unyielding literalness that Congress may, under no circumstances, impose a money exaction or tax for a purpose other than revenue. The present day advocates of this theory usually recognize that Congress may levy a tax to make effective some other power delegated to Congress by the constitution, such as the power to regulate commerce or to control the currency. They insist, however, that in such cases Congress has exercised not its delegated taxing power but its commerce power or its currency power. In other words, the power of taxation granted by article I, section 8 of the constitution is definitely limited to the laying of taxes for revenue only: but in addition to this expressly delegated and definitely limited power, there is derived from the other grants of congressional authority an implied power to levy money exactions which may be called taxes, so that a tax is constitutional which furthers any object within the scope of the delegated powers of Congress even though it is not levied by virtue of the taxing power specifically granted in article 1 , section 8 . To overlook this important distinction puts the adherent of the "revenue only" theory in an entirely false position.

This view that the power of taxation granted to Congress may constitutionally be used only for the purpose of raising revenue is supported by three main arguments which may be briefly reviewed. ${ }^{21}$

1. In its commonly accepted meaning as well as by legal definition, the term "taxation" is confined to the power of gov-

19 Works, VI, 1-59.

20 The Democratic Platform in 1912 contained the following declaration: "We declare it to be a fundamental principle of the Democratic Party that the Federal Government under the Constitution has no right to impose or collect tariff duties except for the purposes of revenue. . . " The Democratic Platform in 1892 contained a practically identical statement.

21 For an excellent presentation of this whole theory of federal taxation, see the valuable article by J. B. Waite, (1908) 6 Mich. Law Rev. 277. 
ernments to raise revenue. All the English dictionaries concur in regarding the purpose of securing money as an inherent attribute of a tax. ${ }^{22}$ The raising of revenue has been commonly recognized as the sine qua non of the taxing power. ${ }^{23}$ This general impression of the layman and the lexicographer has been confirmed with definiteness and precision in the law, which has recognized and emphasized the distinction between money exactions for revenue purposes and money exactions imposed for purposes of regulation or destruction. Charges of the first class are based on the taxing power; those of the second class upon the police power. Commentators ${ }^{24}$ and courts $^{25}$ have again and again insisted upon the observance of this classification. The state governments possess, of course, a general police power for the protection of public health, safety, morals and welfare. As a necessary and reasonable means of exercising this police power the state may levy what, for want of a better term, may be called taxes, which are prohibitive or repressive or regulatory in purpose and effect. In the legal and constitutional sense these taxes are to be regarded as police regulations, and not as exertions of the power of the state to tax. To prove this it is merely necessary to point out that these so-called "taxes" have been subjected to all the constitutional limitations resting upon the police power and when they have been imposed in a manner or for a purpose which cannot be justified under the police power, the courts have not, hesi-

22 Webster defines a tax as "a rate or sum of money assessed on the person or property of a citizen by the government for the use of the nation or state."

${ }^{23}$ While admitting that the purpose to raise revenue is a common attribute of the taxing power, there are those who deny that it is an essential attribute. See infra 261, 265.

24"License fees, occupation taxes, inspection fees, and other like exactions, which are not imposed for the purpose of raising revenue, but for the proper regulation of matters deemed essential to the public safety, health, or welfare, are not 'taxes' in the ordinary and proper sense of that term, and are not governed by the constitutional rules and maxims applicable to taxation, but by those which define and limit the exercise of the police power." Black, Constitutional Law, 3d Ed., 467; Cooley, Constitutional Limitations, 7th Ed. 283, n. 1, 709, n. 1, 713; Cooley on Taxation, 3d Ed. II, 1125; Freund, Police Power, Sec. 25; McClain, Constitutional Law in the U. S., 133; 27 Amer. \& Eng. Ency. of Law \& Proc., 578; 37 "Сyc." 707.

25 Gundling v. Chicago, (1900) 177 U. S. 183, 189, 20 S. C. R. 633,44 L. Ed. 725; Phillips v. Mobile, (1908) 208 U. S. 472, 478, 28 S. C. R. 370 , 52 L. Ed. 578; Reymann Brewing Co. v. Brister, (1900) 179 U. S. 445, 45 L. Ed. 269, 21 S. C. R. 201 ; Pabst Brewing Co. v Crenshaw, (1904) 198 U. S. 17, 49 L. Ed. 925,25 S. C. R. 552; Tanner v. Little, (1916) 240 U. S. 369,60 L. Ed. 691,36 S. C. R. 379. 
tated to declare them unconstitutional. ${ }^{28}$ If, therefore, it should be admitted that the power of taxation belonging to Congress, is exactly the same in nature and scope as that which the states enjoy, a proposition which has been vigorously urged, ${ }^{27}$ it by no means follows that that power affords any basis for the exercise of a general federal police authority by means of regulatory and prohibitive taxation. When the state lays a tax for police purposes, it is exercising one of its admitted powers, the police power. No one will deny that Congress, also, may lay taxes as a means of carrying out its own granted powers. ${ }^{28}$ But the use by the state of the power to lay taxes in aid of an admitted state power can furnish no authority for the exercise by Congress of the power to levy taxes in aid of powers clearly not granted to the national. government.

To regard the power of taxation as in its very nature limited to purposes of revenue is not to deny or discount the truth of Marshall's famous dictum, "the power to tax is the power to destroy." ${ }_{29}$ The two propositions are entirely compatible. This oftquoted maxim, instead of being regarded as a blanket authorization of the unrestrained use of the taxing power for any and all purposes irrespective of revenue, is more reasonably construed as an epigrammatic statement of the political and economic axiom that since the financial needs of a state or nation may outrun any human calculation, so the power to meet those needs by taxation must not be limited even though the taxes become burdensome or confiscatory. ${ }^{30}$. To say that "the, power

26 State v. Ashbrook, (1899) 154 Mo. 375, 55 S. W. 627, 48 L. R. A. 265, 77 A. S. R. 765; Sperry and Hutchinson v. Owensboro, (1912) 151 Ky. 389, 151 S. W. 932; Little v. Tanner, (1913) 208 Fed. 605 (overruled in 240 U. S. 369 on other grounds). Earlier cases are cited by Cooley, Taxațion, II, 1140 .

${ }_{27}$ See infra, p. 267.

28 See infra, p. 261.

${ }^{29}$ McCulloch v. Maryland, (1819) 4 Wheat. (U.S.) $316,431,4$ L. Ed. 579 ; Weston v. City Council of Charleston, (1829) 2 Pet. 449, 7 L. Ed. 481. It should be noted that this statement is in reality obiter dictum. What Marshall was proving was that a state could levy no tax whatever on an instrumentality of the federal government even though the tax was neither burdensome nor destructive. See article by T. R. Powell, Indirect Encroachment on Federal Authority by the Taxing Powers of the States, (1918) 31 Harvard Law. Rev. 321.

30 "The sense of the opinion is that, as a sovereign state, governments may be pressed for money, each may take from its people a portion of their possessions; that this right may be exercised again and again until the whole of the property has been exhausted: In this sense there is a like right in the federal government to destroy." Waite, op. cit., 6 Mich. Law Rev. 292. 
to tax is the power to destroy" is to describe not the purposes for which the taxing power may be used but the degree of vigor with which the power may be employed in order to raise revnue. $^{31}$

2. It is urged, in the second place, that the framers of the federal constitution intended to confer upon Congress the power to tax only for the purpose of raising revenue. ${ }^{32}$ It is true that the clause granting this power contains language susceptible of a more liberal construction. It authorizes the levying of taxes "to pay the debts and provide for the common defense and general welfare of the United States." The power described by these words, however, is the power to tax for the purpose of securing the necessary money with which to pay the public debts and provide for the common defense and general welfare. In other words," "to provide for the common defense and general welfare" is a statement of the objects for which money raised by taxation may be spent rather than a statement of the objects for which the power to tax may be used irrespective of revenue. It is urged that such meagre evidence as is available regarding the meaning attached to this clause by those who framed $\mathrm{it}^{33}$ and by

- 31 This view finds support in Marshall's further comment on the doctrine in the same case: "The people of a state, therefore, give to their government a right of taxing themselves and their property, and as the exigencies of government cannot be limited, they prescribe no limits to the exercise of this right, resting confidently on the interest of the legislator, and on the influence of the constituents over their representatives, to guard them against its abuse." 4 Wheat. (U. S.) 316, 428.

32 Waite, op. cit., 6 Mich. Law Rev. 284; Bruce, Interstate Commerce and Child Labor, (1919) 3 Minnesota Law Review 101; Tucker, op. cit., I, 478.

${ }_{33}$ The problem of the purposes for which Congress was to be authorized to lay taxes evoked little discussion in the Convention of 1787. The Virginia Plan as introduced by Randolph on May 29 contained no separate grant of the taxing power to Congress but provided "that the National Legislature ought to be empowered to-enjoy the legislative rights vested in Congress by the Confederation, and moreover to legislate in all cases to which the separate states are incompetent, etc. . . " Farrand, Records of the Federal Convention, I, 21.

Section 2 of the New Jersey Plan introduced by' Patterson on June 15 provided that Congress "be authorized to pass acts for raising a revenue, by levying a duty or duties on all 'goods or merchandise of foreign growth or manufacture, imported into-any part of the United States, by stamps on paper, vellum or parchment, and by a postage on all letters or packages passing through the general Postoffice, to be applied to such federal purposes as they shall deem proper and expedient." Ibid, I, 243.

The plan for a new constitution proposed by Charles Pinckney on May 29. provided in.Art. IV that "The legislature of the United States shall have the power to lay and collect taxes, duties, imposts and excises." Ibid, III, 595. This was the form in which the clause was reported by the Committee of Detail on Aug. 6. Ibid. II, 181. A, further report from the same committee on Aug. 22 added to the clause as quoted the 
those who discussed it while ratification of the constitution was pending ${ }^{34}$ tends to support the view here urged. The clause was placed in the constitution in order to remedy that serious defect of the articles of confederation arising from the inability of Congress to raise revenue directly. The new government must enjoy this power to raise revenue, and these were the words in which that power was conferred. ${ }^{35}$ That the framers did not intend to give Congress a general police power to be exercised by means of destructive or regulatory taxation is evidenced by two more definite considerations. First, the fundamental principle on which the new national government was to rest was that of enumerated powers. Its founders desired it to deal with a definitely limited group of subjects and no others. They cannot therefore reasonably be presumed to have intended to confer upon Congress, under the guise of the power to lay taxes, the power to deal with any problem of social or economic policy which might be indirectly affected or controlled by an ingenious use of the taxing power. Had they so intended, they would have swept away by this one specific grant of power most of those limitations upon the scope of federal authority which it was the purpose of the other spe-

words, "for the payment of the debts and necessary expenses of the United States." Ibid, II, 366. Among the records of the Committee of Detail was found a proposal in Randolph's writing that Congress should have power "To raise money by taxation, unlimited as to sum, for the past or future debts and necessities of the union." Ibid, II, 142.

On Aug. 25 a motion was lost to add to the clause granting Congress the power to tax the clause "for the payment of said debts and for the defraying the expenses that shall be incurred for the common defense and general welfare." Ibid, II, 408.

34 The Federalist discusses the federal taxing power at length. See Nos. $30-36$ inc. It nowhere suggests that the power could be used for purposes other than revenue.

Sherman and Ellsworth in transmitting a copy of the new constitution to the governor of Connecticut, Sept. 26, 1787, wrote: "The objects for which Congress may apply monies, are the same mentioned in the eighth article of the confederation, viz. for the common defense and general welfare, and for the payment of the debts incurred for those purposes." Farrand, op. cit., III, 99.

McHenry, member of the Convention of 1787 from Maryland, speaking on Nov. 29 before the Maryland House of Delegates, declared: "The power given to Congress to lay taxes contains nothing more than is comprehended in the spirit of the eighth article of the Confederation." Ibid, III, 149.

${ }^{35}$ Art. VIII of the Articles of Confederation had provided that "All charges of war, and all other expenses that shall be incurred for the common cause or general welfare, . . shall be defrayed out of a common treasury. which shall be supplied by the several States, in proportion to the value of all such land within each State, etc. . . " It was the method of raising money, rather than the purposes of taxation which the framers of the Constitution sought to change. 
cific grants of power to build up. ${ }^{36}$ And secondly, had the framers of the constitution desired to have Congress enjoy that generous police power which it has been urged it may exercise through the medium of taxation, is it probable that they would have limited Congress in the exercise of that police power to the inconvenient and indirect agency of taxation? Would they not rather have allowed a reasonable choice of method instead of saying, in effect, "you may exercise a police power, provided only you do it under the guise of taxation?"37

3. Finally, in every case in which the Supreme Court of the United States has been willing to recognize that Congress has levied taxes for purposes other than revenue, it has looked upon these taxes not as exercises by Congress of its granted power to tax, but as means employed for carrying out other delegated congressional powers. And this view has been shared by distinguished legal commentators. In other words, the cases commonly cited to prove that the delegated power of taxation may be used for purposes of regulation and destruction prove nothing more in fact than that the power of Congress to lay taxes may be an implied power derived from other congressional powers, or that Congress may lay taxes as a necessary and proper means of carrying out its other granted powers.

This is, in the first place, the constitutional justification of the prohibitive tariff. While there is no decision of the Supreme Court squarely upon this point, the weight of authority leans to the view that a prohibitive tariff is not an exercise of the taxing power at all, but should rather be classified as a regulation of commerce. $^{38}$ In cases where a tariff is levied not only to raise

${ }^{36}$ Tucker writes: "It is surprising how this sophistical device has been upheld by learned commentators, for it is obvious that, by such construction of the Constitution, Congress may range with no limit but its discretion through the realms of reserved and ungranted powers by means of a clause to tax ad libitum and appropriate at will the money of the people to the promotion of anything through other agencies than its own and to the accomplishment of anything it may deem to be for the common defense and general welfare; for this, in effect, is worse than if the words to provide for the common defense and general welfare' were held to grant the unlimited power claimed, as it incites to profuse expenditure and excessive taxation as the only avenue to the unlimited usurpation of ungranted powers." Op. cit., I, 484. See also Bruce, op. cit., 3 Minnesota Law Review 101-103.

${ }_{37}$ Waite, op. cit., 6 Mich. Law Review 285.

38 The authority most frequently cited is Cooley who writes: "Constitutionally a tax can have no other basis than the raising of a revenue for public purposes, and whatever governmental exaction has not this basis is tyrannical and unlawful. A tax on imports, therefore, the purpose of which is, not to raise a revenue, but to discourage and indirectly prohibit 
revenue but also for the protection of home industry, it may be regarded as an exercise of both the taxing and the commerce powers. $^{39}$ Even Story, who repudiates the doctrine of taxation for revenue only, regards the protective tariff as a means of regulating foreign commerce; $;^{40}$ and his view would probably be followed by any court before which the issue could be raised.

In the second place, Congress has laid destructive taxes as a means of regulating the currency. In 1866, shortly after the establishment of the national banking system, Congress laid a prohibitive tax of ten per cent upon state bank notes in order to protect the notes of the new national banks from their competition. ${ }^{41}$ The Supreme Court of the United States upheld the constitutionality of this tax in the case of Veasie Bank vs. Fenno, decided in 1869.42 Counsel for the bank urged upon the court that the tax was invalid because it was so excessive as to indicate a purpose on the part of Congress to destroy the thing taxed rather than to raise revenue. The court replied:

"The first answer to this is that the judicial cannot prescribe to the legislative department of the government limitations upon the exercise of its acknowledged powers. The power to tax may be exercised oppressively upon persons, but the responsibility of the legislature is not to the courts but to the people by whom its members are elected. So if a particular tax bears heavily upon a corporation, or a class of corporations, it cannot, for that reason only, be pronounced contrary to the constitution." .

some particular import for the benefit of some home manufacture, may well be questioned as being merely colorable, and therefore not warranted by constitutional principles. But if any income is derived from the levy, the fact that incidental protection is given to home industry can be no objection to it, for all taxes must be laid with some regard to their effect upon the prosperity of the people and the welfare of the country, and their validity cannot be determined by the money returns. .: And perhaps even prohibitory duties may be defended as a regulation of commercial intercourse." Principles of Constitutional Law, 3d Ed., 58. See also Hall. Constitutional Law, 181 ; Watson on Constitution, I, 485 n. s. ; Willoughby, op. cit., I, 607. See contra Pomeroy's statement: "A protective tariff is certainly not indispensable to the execution of the power to lay taxes; but it is so certainly one of the methods of exercising that power." Constitutional Law, 217.

39 "The protective tariff laws are measures properly enacted under the express power to raise revente and to regulate foreign commerce." McClain, op. cit., 88 .

$4^{\circ}$ Op. cit., Secs. 1084-1094. But note that Story also regards it as proper to base protective tariffs on the taxing clause, ibid, Secs. 962-965. $\mathrm{He}$ says, however, that the commerce power is the one from which the right to enact such tariffs "is more usually derived." Ibid, Sec. 763.

41 Act of July 13, 1866, 14 Stat. at L. 146.

42 (1869) 8 Wall. (U. S.) 533, 19 L. Ed. 482. 
It then went on to say that:

"Under the constitution the power to provide a circulation of coin is given to Congress . . . Having thus, in the exercise of undisputed constitutional powers, undertaken to provide a currency for the whole country, it cannot be questioned that Congress may, constitutionally, secure the benefit of it to the people by appropriate legislation. To this end, Congress has denied the quality of legal tender to foreign coins, and has provided by law against the imposition of counterfeit and base coin on the community. To the same end, Congress may restrain, by suitable enactments, the circulation as money of any notes not issued under its own authority. Without this power, indeed, its attempts to secure a sound and uniform currency for the cointry must be futile. Viewed in this light, as well as in the other light of a duty on contracts or property, we cannot doubt the constitutionality of the tax under consideration."

The first of the paragraphs quoted has frequently been cited as authority for the statement that Congress can tax to an unlimited degree for any purpose it chooses, irrespective of revenue and without fear of judicial interference. ${ }^{43}$ While it is hard to see in the passage much more than a statement of the perfectly obvious doctrine that a tax, otherwise legal, cannot be held void because a court thinks it is too high, it must be admitted that it does indicate an opinion on the part of the court that the power which is being exercised is the taxing power. Since the power is quite obviously not being employed to raise revenue, such. a view conflicts with the theory of taxation for revenue only which now is under consideration. But whatever comfort those who contend for a federal police power through taxation may derive from this statement will be minimized if not destroyed by the second of the paragraphs quoted, wherein it is plainly stated that this destructive tax is merely a convenient method of protecting the national currency. As a matter of fact, the Supreme Court in subsequent decisions ${ }^{44}$ as well as

43 This is apparent from a scrutiny of the debates in Congress upon any of the regulatory or destructive taxes which have been passed. See in fra, p. 266.

44 Miller, J. in The Head Money Cases said: "In the case of Veazie Bank v. Fenno, the enormous tax of eight per cent [it was in fact ten per cent] per annum on the circulation of state banks, which was designed, and did have the effect to drive all such circulation out of existence, and was upheld because it was a means properly adopted by Congress to protect the currency which it had created; namely the legal tender notes and the notes of the national banks. It was not subject. therefore, to the rules which would invalidate an ordinary tax pure and simple." (1884) 112 U: S. 580, 596, 5 S. C. R. 247, 28 L. Ed. 798. In National Bank v. U. S., (1879) 101 U. S. 1, 6, 25 L. F.d. 979, the court 
numerous text writers ${ }^{45}$ and other authorities ${ }^{46}$ have with practical unanimity regarded the Veazie Bank case in this light and leaned to the opinion that the constitutional basis for the levy imposed by the act of 1866 was the currency power and not the taxing power. ${ }^{47}$

In one or two other cases of less importance the Supreme Court has recognized the distinction between levies made under the taxing power and those made under other granted powers of Congress. In the Head Money Cases ${ }^{48}$ involving the validity of a duty of fifty cents for every alien immigrant brought by vessel into the United States, the court met such objections to the law as rested upon its alleged non-conformity to the constitutional requirements regarding federal taxation by declaring that "the true answer to all these objections is that the power exercised in this

commented on the Act of July 13,1866, as follows: "The tax is on the notes paid out, that is, made use of as a circulating medium. Such a use is against the policy of the United States. Therefore the banker who helps to keep up the use of paying them out, that is, employing them as the equivalent of money in discharging his obligations, is taxed for what he does. The tax was no doubt intended to destroy the use; but that, as has just been seen, Congress had the power to do." Flint v. Stone Tracy Co., (1911) 220 U. S. 107, 31 S. C. R. 342, 55 L. Ed. 389, Ann. Cas. 1912B 1312.

${ }^{45}$ Hall, op. cit., 311 ; Hare, op. cit., I. 269; McClain, op. cit., 133; Willoughby, op. cit., I, 580 .

46 Senator Hoar declared in the Senate in 1902 (in discussing the oleomargarine tax passed in that year), "We had no right to suppress the state banks in the time of war merely because the wildcat bank was an evil, it being confined to state business and authorized by state power; but when we established a national currency we had a right by any method of constitutional action to protect that national currency against the competition or rivalry of any other. Therefore we had the right to tax out of existence the currency of the state banks, just as we should have had the right to pass a law directly that no state bank should issue currency in competition with ours." Cong. Rec., Mar. 26, 1902, Vol. 35,3280 .

47 Those who adhere to the second and third of the three general views of the scope of the federal taxing power place a different interpretation on the Veazie Bank Case. There is eminent authority holding the power therein discussed to be the taxing power. See Cooley, Constitutional Limitations, 681, n. 685; Cooley, Principles of Constitutional Law, 58; Pomeroy, op. cit., 233. See also dissenting opinion of Holmes, J. in Hammer v. Dagenhart, (1918) 247 U. S. 251, 277, 62 L. Ed. 1101, 38 S. C. R. 529. Senator Spooner declared in the Senate in 1902 that the tax of 1866 did not rest on the currency power but that it was upheld "not because it was required in aid of another power, but because under the plain language of Sec. 8, it [Congress] had the power to do it." Cong. Rec., Apr. 1, 1902, Vol. 35, 3506.

${ }^{88}(1884) 112$ U. S. 580,5 S. C. R. 247, 28 L. Ed. 798. The court used these words: "If this is an expedient regulation of commerce by Congress, and the end to be attained is one falling within the power, the act is not void, because, with a loose and more extended sense than was used in the constitution, it is called a tax." Ibid, p. 596. 
instance is not the taxing power. The burden imposed on the ship owner by this statute is the mere incident of the regulation of commerce." Thus the requirement that a stamp be placed on goods intended for export in order to prevent fraud is not levying a tax even though a charge is made for the stamp. ${ }^{43}$ But if the charge is made for purposes of revenue rather than regulation it becomes a tax. ${ }^{50}$

Use of Taxing Power Not for Revenue But in Furtierance of Delegated Congressional Authority

The second view of the real scope of the federal taxing power may be regarded as middle ground between the revenue only doctrine just discussed and the theory that the power may be used for general police purposes. This second position admits the propriety of using the power of taxation for purposes other than revenue, but not for all such purposes. Its adherents claim that the grant of taxing power may be exercised for purposes of revenue plus any other purposes lying within the scope of delegated congressional authority. It has been seen that those who defend the revenue only theory are under the necessity of maintaining that when taxes are laid by Congress in order to regulate commerce or protect the currency, those taxes must be viewed constitutionally not as expressions of the granted power of taxation but rather as expressions of the power to regulate commerce or the currency respectively. The constitutional basis for such taxes is not the power of taxation at all but the particular power in aid of which the taxes are laid. Those who hold the second view, now being analyzed, maintain that taxes laid in order to help regulate commerce are exercises of the granted power of taxation and that it is quite proper to employ the taxing power as a means of supplementing and supporting any other granted power of Congress. Having thus admitted that the power of taxation itself, not as an implied power but as a granted power, may be used for purposes other than the raising of revenue, it is necessary to defend the position that there are still definite limits upon its scope. It is necessary to show why, from a constitutional viewpoint, the power of taxation may be used to regulate commerce or the national currency but not to regulate such mat-

49 Pace v. Burgess, (1875) 92 U. S. 372, 23 L. Ed. 657.

50 Almy v. California. (1860) 24 How. (U. S.) 169, 16 L. Ed. 655. 
ters as child labor, lotteries, ${ }^{51}$ or political campaign contributions. ${ }^{52}$

The argument in support of this position may be summarized as follows: The powers of Congress are enumerated and delegated. The grants of power to Congress taken together were clearly intended to constitute the sum total not only of the powers confided to that body but also of the legislative objects about which or in furtherance of which Congress might exercise those powers. In short, the various delegations of power must be regarded not merely as legislative instruments placed in the hands of Congress to be used for any or all purposes; they must be regarded also as the ends, objects, or purposes for which Congress may exercise legislative power. This, it is stated, is what Marshall had in mind when he said, "Let the end be legitimate, let it be within the scope of the constitution, and all means which are appropriate, etc. . . . are constitutional;"53 and when in the same case, he declared, "Should Congress, under the pretext of executing its powers, pass laws for the accomplishment of objects not entrusted to the government, it would become the painful duty of this tribunal, should a case requiring such a decision come before it, to say that such an act was not the law of the land."54 It follows, therefore, that when Congress attempts, through the

51 A destructive tax on lotteries was urged upon Congress with great vigor. See remarks of Senator White (now Chief Justice) of Louisiana upon the propriety of this legislation: "When my people were clamoring for its suppression and crowding upon me petitions to introduce a bill suppressing the Louisiana Lottery by the exercise of the power of federal taxation, I said to them, "Great as is this evil, there is an evil yet greater, and that is the disruption and the destruction of all the great principles of our government by calling upon the Federal Government to do an illegal and unconstiutional thing. . . I declined to introduce a bill taxing the Louisiana Lottery by the Federal Government because I thought it violated the Federal Constitution." Cong. Rec., July 21, 1892, Vol. 23, 6519. Such bills were, however, introduced. Compare with this the view of Judge Cooley, set forth in an article advocating such a tax, infra, note 81 .

32 Senator Thomas (Col.) introduced an amendment to the war revenue bill of 1919 , providing for a tax of $100 \%$ on any campaign contribution in excess of $\$ 500$ in any primary or election campaign for the nomination or election of presidential electors, senators, or members of the House. Cong. Rec., Oct. 10, 1918, Vol. 56, 11169. The amendment was defeated.

${ }^{53}$ McCulloch v. Maryland, (1819) 4 Wheat. (U. S.) 316, 421, 4 L. Ed. 579.

${ }^{54}$ Ibid, p. 423. For an analysis of this argument see Tucker, op. cit., I : Green, The Child Labor Law and the Constitution, Ill. Law Bull., April, 1917, 16. Compare Marshall's statement, "Congress is not empowered to tax for purposes which are within the exclusive province of the state." Gibbons v. Ogden, (1824) 9 Wheat. 1, 199, 6 L. Ed. 23.

See also Kent, Commentaries, 13th Ed. I 279. 
instrumentality of a granted power such as that of taxation, to regulate or control a subject matter nowhere confided to its authority by virtue of any delegation of power, such as the subject of child labor, it has exceeded its powers, usurped the reserved authority of the states, and violated the tenth amendment. ${ }^{55}$

This same doctrine may be put in slightly different form by saying that in exercising the powers delegated to it by the constitution Congress must be regarded as exercising them under the implied limitation that they shall be employed only for the objects or ends confided by the constitution to congressional authority. The taxing power has long since been held subject to two other implied limitations, the binding force of which there is no disposition to question: one is the limitation of public purpose in respect to the use of the money raised by taxation $;^{58}$ the other is the limitation implied from the essential nature of our federal

55 This doctrine has been accepted by the supreme court of the Commonwealth of Australia. In King v. Barger, (1908) 6 Com. L. R. 41, a federal tax on articles manufactured in the states, dependent upon the rate of wages paid and designed to control such wage rate, was held to be invalid on the ground that the federal government had no authority to control wages in the states. The following excerpts indicate the main features of the reasoning of the court:

Higgins, J., "This act is not a taxing act. This is quite a novel form of legislation, and, if held to be valid, will give to the Commonwealth Parliament complete control over everything which was intended to be reserved to the states. Under the guise of a taxing act with exemptions, the Commonwealth Parliament could control the whole of the business and social relations of the people of the Commonwealth, and the provisions of the constitution, intended to reserve to the states the right of managing their internal affairs, would be worthless. (P. 47)

The Commonwealth Parliament can tax any person and any thing; and it can divide persons and things into classes for the purpose of taxation. But the moment the particular discrimen for distinguishing between one class and another in itself involves a regulation of conduct which is within the exclusive power of the state legislature, the Commonwealth legislation is invalid:" (P. 52.)

Isaacs, C. J., "The power of taxation granted to the Commonwealth Parliament does not authorize the impairment of the power reserved to the states to regulate wages." (P. 49.) Par. $107 \mathrm{Ch}$. V of the Commonwealth of Australia Constitution Act reads: "Every power of the Parliament of a colony which has become or becomes a state, shall, unless it is by this Constitution exclusively vested in the Parliament of the Commonwealth or withdrawn from the Parliament of the state, continue as at the establishment of the Commonwealth, or as at the admission or establishment of the state, as the case may be."

Compare also the last clause in the following sentence from the Veazie Bank case, supra: "It would undoubtedly be an abuse of the power [of taxation] if so exercised as to impair the separate existence and independent self government of the states, or if exercised for ends inconsistent with the limited grants of power in the constitution." P. 451 . See Tucker, op. cit., I, 373.

${ }^{56}$ Loan Association v. Topeka, (1875) 20 Wall. (U.S.) 655, L. Ed. 455. This case involved the taxing power of the states but the principles 
system which forbids Congress to tax the governments, agencies, or functions of the state. ${ }^{57}$ It is urged that the taxation by Congress of the salary of a state judge is no more subversive of the fundamental principles of our constitutional system than the use by Congress of its taxing power to destroy child labor within the states. ${ }^{58}$ For to what purpose did the framers of the constitution reserve certain subjects to the exclusive jurisdiction of the states if Congress, under the guise of an exercise of the power to tax, may step in and control those subjects? To admit the power to tax on the part of Congress for any and all purposes would "abrogate and destroy every limitation found in the constitution and every reservation in favor of the states." 59

It is interesting to note that the present Chief Justice of the United States seems to share the view now under consideration. $\mathrm{Mr}$. White was United States senator from Louisiana at the time a destructive tax upon cotton and grain futures was being debated in Congress in 1892. ${ }^{60}$ At that time he expressed himself vigorously and at length upon the constitutionality of the proposed tax, taking the position that such "subterfugeous and cheating" use of the taxing power was clearly outside the constitutional authority of Congress: He took occasion in the course of his argument to draw the distinction between the use of regulatory or destructive taxation in aid of the exercise of delegated congressional power and its use for purposes not so delegated.

"In other words, I contend," he declared, "that where power to destroy exists, the use of a wrong instrumentality to do the destruction, may be the abuse of an instrumentality but not an abuse of power, because the power to destroy is vested. But where the power to destroy does not exist, the use of an instrumentality to destroy that which there is no power to destroy is

involved are applicable with equal force to the federal taxing power. It should be noted that the limitation of public purpose does not rest on the due process of law clause as has been sometimes assumed.

57 Collector v. Day, (1871) 11 Wall (U. S.) 113, 20 L. Ed. 122; Fifield v. Close. (1867) 15 Mich. 505.

58 "The principle is equally applicable to a case where the court can see that a power of government is called into play not for its professed object but solely for the purpose of defeating rights that cannot be destroyed consistently with any other of the principles upon which the constitution rests, but there is no principle more fundamental than the principle in fulfillment of which the national government was created of circumscribed powers, each conferred for the accomplishment of a specified object, purpose or end." Green. op. cit., Ill. Law Bull., April, 1917, 26.

5 Remarks of Senator White. Cong. Rec., July 21, 1892, Vol. 23, 6516.

60 The question of the constitutionality of this bill was discussed at great length. Senator White's long speech against the bill is found in Cong. Rec., July 21, 1892, Vol. 23, 6513-6520. The bill was defeated. 
not alone an abuse of the instrumentality but a usurpation of power itself." $" 11$

And in commenting upon the Veazie Bank case, he went on to state that according to that decision the destructive tax on state bank notes could be regarded as either a prohibition or a tax. If it be viewed as a prohibition, then it is merely an exercise of the admitted power of Congress over the currency. If it be viewed as a tax, it is not unconstitutional, "because Congress had the power to use the taxing power to prohibit that which it had the right to prohibit under another provision of the constitution." But he was emphatic in his belief that this affords no precedent for the use of the power to tax for purposes not confided to congressional authority. ${ }^{62}$

Destructive or Regulatory Taxation for Police Purposes Outside the Scope of Delegated Congressional Authority

It is clear that Congress has not acceded to either of the views thus far presented. It has regarded the purposes for which it may use its power to tax as limited neither to the raising of revenue nor to the furtherance of objects within its delegated authority. It has legislated more than once upon the theory that the power to tax is available as a means or instrument for accomplishing any purpose which will further the national welfare and that Congress may regulate or destroy by taxation things over which it plainly has no direct authority. Such legislation may be briefly reviewed.

1. Instances of Federal Taxation for General Police Purposes. $^{.3}$ In 1886 it was proposed to levy an excise tax of ten cents per pound upon all oleomargarine manufactured in the

61 Ibid, 6517.

62 Ibid, 6517. He further pointed out that the power to lay a prohibitive tariff did not furnish a precedent for the tax under discussion. To argue that it does, "overlooks the clear distinction between the nature of the taxing power lodged in the federal government for the purpose of imposts and the nature of the taxing power lodged in the federal government for the purpose of internal taxation. . . . When the federal government deals with imposts the constitution has vested in it the power which would be vested in any government in that regard. . . . No power as to imposts was reserved in the states by the federal constitution. All the lawful powers of government which could be exercised in that particular passed into the life and being of the federal government by the lodgment in that government of the power to levy imposts-imposts deal externally beyond our borders. Beyond those borders the power of the federal government was restricted and restrained by no limitation resulting from a reservation in the constitution." Ibid, 6516.

${ }^{63}$ No attempt has here been made to search out all the cases in which Congress has laid taxes for purposes of regulation. Only those are here treated regarding which there has been sharp controversy on the point of constitutionality. 
United States. After considerable debate in both houses of Congress, the tax was reduced to two cents per pound, a rate so low as to preclude the tax from being classed as destructive in character. ${ }^{64}$ In 1902, however, a tax of ten cents per pound was placed upon all oleomargarine colored to look like butter ; ${ }^{\mathbf{6 5}}$ and this tax has accomplished the purpose for which it was admittedly imposed, the destruction of the business of manufacturing colored oleomargarine. In 1892 it was proposed in Congress to place a license tax of $\$ 1000$ upon all brokers or dealers engaged in the selling of cotton or grain on future contracts or options and a tax of five cents per pound or twenty cents per bushel upon all products so sold. ${ }^{\text {Be }}$ This tax did not become law, but in 1914 Congress did impose a tax of two cents per pound upon all cotton sold on future contracts. ${ }^{67}$ In 1890 a tax of ten dollars was imposed upon the sale of smoking opium. ${ }^{68}$ In 1914 this tax was raised to $\$ 300$ per pound. ${ }^{69}$ In 1912 Congress drove out of existence the manufacture of matches made from poisonous phosphorus by subjecting these matches to the crushing tax of two cents per hundred. ${ }^{70}$ Finally, as has been already stated, Congress has placed a tax of ten per cent upon the net profits of establishments employing children. ${ }^{71}$

An examination of the congressional debates on these measures makes perfectly clear that Congress was not trying to raise revenue but was trying to exercise police power in matters outside the scope of its delegated authority. The oleomargarine taxes were openly defended upon the ground that the legitimate dairy interests of the country must be protected against the destructive competition of a product alleged to be not only inferior but positively dangerous to health. ${ }^{72}$ The taxes on options or sales on future contracts were urged as necessary restraints on com-

64 Act of Aug. 2, 1886, 24 Stat. at L. 209.

65 Act of 1902, 32 Stat. at L. 193.

${ }^{66}$ The text of this proposed measure is printed in the Cong. Rec., July 21, 1892, Vol. 23, 6514 .

67 Act of Aug. 18, 1914, 38 Stat. at L. 693. This was declared unconstitutional by a United States district court because, being a revenue measure, it originated in the Senate rather than in the House of Representatives as required by art. I, sec $7, \mathrm{cl}$. 1 of the constitution. Hubbard v. Lowe, (1915) 226 Fed. 135. It was re-enacted as Act of Aug. 11, 1916, 39 Stat. at L. 476.

${ }_{68}$ Act of Oct. 1, 1890, 26 Stat. at L. 5670.

69 Act of Jan. 17, 1914, 38 Stat. at L. 277.

70 Act of April 9, 1912, 37 Stat. at L. 81. The constitutionality of this act has never been passed upon by any court.

71 Supra. note 10 .

72 See debates on H. R. 9206, Index to Cong. Rec., Vol 35. 
mercial gambling. ${ }^{73}$ When the tax on white phosphorus matches was being discussed in the Senate in 1912, Senator Lodge, who was sponsoring the bill, declared without hesitation, "The real purpose of the bill is to destroy an industry that ought to be destroyed." 74 He was equally frank as to the purpose of the recent child labor tax, as were most of the other friends of the bill. $^{75}$ In fact, the debates on this measure show that the Senate Committee on Finance, in estimating the revenue expected from the various taxes included in the Revenue Act of 1919, placed no estimate opposite the child labor tax, indicating that they did not expect any revenue to flow from it into a sadly depleted treasury. ${ }^{76}$

2. Argument in Support of This Theory. In order to show that Congress enjoys the broad power of taxation for police purposes it is necessary at the outset to dispose of the revenue only theory already discussed. ${ }^{77}$ There are two steps in this process of refutation. It is pointed out, first, that the power of taxation granted to Congress is no different in character and no more limited, save as to the specific requirements of apportionment and uniformity and the specific prohibition against export taxes, than is the power of taxation possessed by the states of the union or by any other sovereign government. As Senator Edmunds expressed it in the debate on the oleomargarine tax statute of 1886, "the taxing power of the United States is just as extensive, just as supreme, just as illimitable as the taxing power of every state is." "rs Gray states this position even more strikingly in the following passage commenting upon the intentions of the framers of the federal constitution:

73 See debates on Senate bill 110; Index to Cong. Rec., Vol. 51.

74 Cong. Rec., April 3, 1912, Vol. 4235. In regard to the same bill Mr. Longworth (Ohio) declared in the House, "It is the purpose of the bill to destroy it [the poisonous match industry] and that is the reason I am for the bill. because I want it stamped out." Ibid, 3973.

75 Supra, notes 4 and 12.

76 In response to a question on this point. Senator Simmons, chairman of the Committee on Finance, stated: "I can only say to the Senator that I do not think there was an estimate made as to the amount of revenue that would be raised by it ... and I do not think any one suggested that any would be derived." Cong. Rec., Vol. 57, 612. It is interesting to compare this with the argument of Mr. Miller Outcalt for the plaintiff in error in the McCray case: "It is not out of place to advert to an overflowing treasury, and the expediency which this same Congress felt in reducing the revenue derived under the Spanish War Acts, in this same year, by an amount equal to $\$ 70,000,000$. The law was avowedly not a revenue measure but a police regulation." 43 L. Ed. 78, 80.

77 Supra, p. 251.

78 Cong. Rec., July 19, 1886, Vol. 17, 7139. 
"The example of a strong general government which they had in mind, and the only one with which most of them were familiar, was the government of Great Britain. The powers of that government were well known to them, its machinery had been copied in most of the states. In view of these facts it may be generally stated that in their bestowal of powers on the general government and in their restriction of those powers (particularly of taxing powers, since dispute as to taxation was one of the chief causes of the Revolution) they intended:

"1. To grant to the general government those powers usually exercised by the government of Great Britain, and in matters of taxation to grant the same general authority of classification and selection as was possessed by the British government and by the state governments modeled upon it.

"2. To restrict those powers thus granted in such a way as to prevent discrimination among the states."79

In short, unless state governments and the governments of sovereign nations generally at the time of the formation of our national government were limited in the use of their taxing powers to the raising of revenue, there is no reason to assume that the taxing power granted to Congress was so limited.

This raises the question, in the second place, whether the power of taxation enjoyed by sovereign governments at this period was thus limited to the raising of revenue. On this point there can be no clearer or more definite statement than that of Story's:

"Nothing is more clear, from the history of commercial nations, than the fact that the taxing power is often, very often applied for other purposes than revenue. It is often applied as a regulation of commerce. It is often applied as a virtual prohibition upon the importation of particular articles, for the encouragement and protection of domestic products, and industry; for the support of agriculture, commerce and manufactures, for retaliation upon foreign monopolies and injurious restrictions; for purposes of state policy and domestic economy; sometimes to banish a noxious article of consumption; sometimes, as a bounty upon an infant manufacture, or agricultural product; sometimes, as a temporary restraint of trade; sometimes, as a suppression of particular employments; sometimes, as a prerogative power to destroy competition and secure a monopoly to the government.

"If, then, the power to lay taxes, being general, may embrace, and in the practice of nations does embrace, all these objects, either separately or in combination, upon what foundation does the argument rest which assumes one object only, to the exclu-

${ }^{79}$ Limitations of the Taxing Power, p. 350. 
sion of all the rest, which insists, in effect, that because revenue may be one object, therefore it is the sole object of the power ...?" 80

Among the eminent authorities who have agreed with this view may be mentioned Judge Cooley, who, in 1892, in urging Congress to place a destructive tax on lotteries, declared, "Revenue is not and has never been the sole object of taxation."

In the third place, it should be noted that the constitutional clause granting the power of taxation seens to repudiate the revenue only doctrine. By the plain words of that clause, Congress enjoys the power to "lay taxes, to pay the public debts and provide for the common defense and general welfare." Now, as Story pertinently inquires:

"If the common defense or general welfare can be promoted by laying taxes in any other manner than for revenue, who is at liberty to say that Congress cannot constitutionally exercise the power for such a purpose? No one has a right to say that the common defense and general welfare can never be promoted by laying taxes, except for revenue. No one has ever yet been bold enough to assert such a proposition." 82

That Hamilton placed a similar broad construction upon this clause is evidenced by the fact that he defended the constitutionality of the protective tariff as an exercise of the congres-

${ }^{80}$ Commentaries, Sec. I, 965, 966. For analysis in this respect of the taxes imposed by England to which the American colonists. took exception see Farrand, The Development of the United States, p. 37. Farrand quotes Madison's statement made after the Revolution, that "The line of distinction between the power of regulating trade and that of drawing revenue from it, which was once considered the barrier of our liberties, was found, on fair discussion, to be absolutely undefinable." Ibid, 38 See also Story, op. cit.. II, Sec. 1080. For careful argument from the standpoint of economics that taxes laid tor purposes of regulation and destruction should be subsumed under the power of taxation and not under the police power, see Seligman, Essays in Taxation, pp. 402-406, 411-413.

${ }^{81}$ Federal Taxation of Lotteries, (1892) Atlantic Monthly, Vol. 69, 523. Supplementing the phrase quoted in the text, Judge Cooley adds that the lawmaker "must nct aim to make his law as productive as possible. but rather to make the demand upon the people as little burdensome as may be, and at the same time. as far as possible, incidentally beneficial." Commenting further upon the proposed tax he says: "Such taxation would, of course. contemplate no revenue to the government. It would be imposed for the express purpose of destroying altogether the institutions which, by any unfriendly action of Congress, taken with the express intent of destruction and shaped professedly to that end, it would be powerless to reach. It would, in other words, be making a practical application by the federal government of the legal anhorism that 'a power to tax is a power to destroy.' Ibid, p. 526. Arguments for and against the tax are discussed in the article. Compare with the statement of same writer in his work on Taxation, 3d Ed. I, 191.

82 Commentaries. I. 
sional taxing power for the purpose of providing for "the common defense and general welfare." ${ }_{83}$

After dealing thus with the revenue only theory of the federal taxing power, the friends of the child labor tax and similar legislation, in order to establish their case, must still demolish the proposition that Congress may use its power of taxation for only such purposes as fall within the scope of the other delegated powers of Congress. ${ }^{84}$ The argument on this point may be summarized thus: In the first place, while Congress enjoys only delegated powers, those powers, save when limited by an express restriction or prohibition, are plenary and complete. This is elementary constitutional law. ${ }^{85}$ "Except when expressly limited, . . . a power granted to the federal government is construed to be absolute in character." 86 This means that apart from these specific exceptions Congress has the same power to lay taxes or to regulate commerce as is possessed by the British Parliament or any other sovereign government in the world. ${ }^{87}$ Its granted powers do not shrink or melt away by the insidious working of implied restrictions or reservations. Secondly, it must be remembered that what section 8 of article $I$ of the constitution grants to Congress is "power." Nothing is said about the purposes for which the various grants of power there delegated are to be used. The grant stands as an independent and self-sufficient delegation of authority. Congress is not given a list of topics about which it is to be allowed to pass laws; nor is it given merely a set of legislative tools or methods to be used in doing a certain limited group of assigned tasks and in the use of which, to borrow Professor Powell's apt phrase, Congress "suffers the limitations of the player at jackstraws," 88 fearful

${ }^{83}$ Report on Manutactures, Dec. 5, 1791. Works, Lodge Ed., Vol. IV, 151. It should be noted, however, that Hamilton's argument did not proceed on the assumption that no revenue would be raised by the protective tariffs proposed.

84 Supra, p. 261.

85 "But it must not be forgotten that when the constitution was adopted there came into existence a nation (as distinguished from a league of states) which possessed absolute and unlimited inherent powers." Black, op. cit., 35; Hall, op. cit., 255; Hare, op. cit., 94; McClain, op. cit., 43; Pomeroy, op. cit., 70. McCulloch v. Maryland, supra, p. .05 ; United States v. Cruikshank, (1876) 92 U. S. 542, 550, 23 L. Ed. 588. ${ }^{86}$ Willoughby, op. cit., I, 54.

${ }^{87}$ Supra, p. 268. Story, op. cit., II, 1081. p. 730 .

The Child Labor Decision, The Nation, June 22, 1918, Vol. 106, 
always of trespassing on the domain of state authority. ${ }^{80}$ It is given the power to lay taxes and to coin money and to regulate commerce and these powers are to be used in the broad discretion of Congress for the promotion of the national welfare. Finally, by very definition it is utterly impossible for the reserved powers of the states to operate as a limitation upon the scope or method of operation of the powers delegated to Congress by the constitution. Such a conception involves a flat contradiction in terms. What are the reserved powers of the states but the powers left after the powers of Congress have been delegated? ?0 Curious indeed would be the arithmetical process of subtraction in which the remainder, somehow rendered inviolable in advance, helped determine the size of the subtrahend. And yet precisely this absurdity is involved in the theory that the reserved powers of the states have become transformed into a sort of ark of the covenant which Congress in the exercise of its granted authority must not touch. If a power is delegated to Congress, then by virtue of that very fact there can be no reserved power of the states with which it could in any way or under any circumstances conflict. ${ }^{91}$

If Congress is not limited in using its power to tax to the raising of revenue or to such purposes as may be subsumed under the grants of power in article I, it follows that that power may be wielded generously in any way which will promote the common defense and general welfare. It may stimulate industry; it may regulate the size of incomes or private fortunes; it may

89 "The question then is narrowed to whether the exercise of its otherwise constitutional power by Congress can be pronounced unconstitutional because of its possible reaction upon the conduct of the states in a matter upon which I have admitted that they are free from direct control. I should have thought that that matter had been disposed of so fully as to leave no room for doubt. I should have thought that the most conspicuous decisions of this Court had made it clear that the power to regulate commerce and other cunstitutional powers could not be cut down or qualified by the fact that it might interfere with the carrying out of the domestic policy of any state." Dissenting opinion of Mr. Justice Holmes, Hammer v. Dagenhart, supra.

9n "The powers not delegated to the United States by the Constitution, nor prohibited by it to the states, are reserved to the states respectively, or to the people." Constitution of U. S., Amendment X.

${ }_{91}$ Conmpare Professor Powell's argument on this point in respect to the Keating-Owen Act: "If the child labor law was a proper exercise of the power to regulate interstate commerce, it was by the explicit terms of the tenth amendment nct an exercise of a power reserved to the states. If it was not a proper exercise of the power to regulate interstate commerce, it was unconstitutional, and nothing more need be said ahout it." The Child Labor Law. the Tenth Amendment and the Commerce Clause, (1918) 3 So. Law Quar. 175. 
suppress vice or other conditions fraught with menace to the people. In short, questions which may arise regarding the purposes for which Congress uses its power of taxation are questions solely of legislative policy and not in any sense questions of constitutional law. ${ }^{92}$

The right to use the taxing power for these broad purposes would not, even in the judgment of its advocates, warrant its exercise in such a way as to destroy fundamental private rights. Should Congress impose a tax of a thousand dollars upon all persons who ate bread or were members of the Roman Catholic Church, the court would of necessity decide that such an exercise of the power to tax was an invasion of the rights which are, in any free government, inviolable. ${ }^{93}$ Such a limitation would clearly be in line with the theory upon which the Supreme Court has held that taxes may be levied only for a public purpose. ${ }^{94}$ But these limitations in behalf of the fundamental rights of the citizen would not interfere with the use of the congressional taxing power for any purposes related to the common defense and general welfare of the nation.

\section{The Problem of Objective Constitutionality}

Thus far the purposes for which Congress may use its power to tax have been considered in the light of general constitutional

92 After adverting to the implied restriction that Congress may not tax the states or their instrumentalities, Cooley states: "With the exception of cases resting on like or kindred reasons to those suggested, the protection as against the abuse of the federal power to tax must be looked for in the good sense of the representatives of the people, and in keeping alive the feeling that for all improper legislation they may be held to strict accountability by their constituents." Op. cit., Atlantic Monthly, Vol. 69, 534. "In selecting objects of taxation we have a right to keep in mind, as every Congress has kept in mind, the general welfare of the people of the United States. The object of taxation is revenue. The motive with which, for one, I vote to select this particular article for taxation is the interest, as I understand it, of the people." Speech of Senator Spooner on Oleomargarine Tax Act of 1902, Cong. Rec., April 1, 1902. Vol. 35, 3505 .

${ }_{93}$ "Let us concede that if a case was presented where the abuse of the taxing power was so extreme as to be beyond the principles which we have previously stated, and where it was plain to the judicial mind that the power had been called into play, not for revenue, but solely for the purpose of destroying rights which could not be rightfully destroyed consistently with the principles of freedom and justice upon which the constitution rests, that it would be the duty of the courts to say that such an arbitrary act was not merely an abuse of a delegated power, but was the exercise of an authority not conferred." White. C. J. in McCray v. U. S., (1904) 195 U. S. 27, 64, 24 S. C. R. 769, 49 L. E.d. 78, 1 Ann. Cas. 561 .

${ }^{94}$ Loan Association v. Topeka, supra. 
principles. The questions discussed here have been those which each member of Congress must settle in his own mind before voting for a taxing bill regarding which these controversies might arise, since he is bound by his oath of office to support the constitution. They have all been concerned with the broad issue: Is the use of the taxing power for'general police purposes defensible on sound constitutional principles? They all relate, therefore, to what has been aptly termed the problem of subjcctive constitutionality. ${ }^{95}$

There remains to be considered what may be called the problem of objective constitutionality. Assuming for the sake of argument that the child labor tax or some analogous act violates sound constitutional principles, can the Supreme Court actually get hold of that unconstitutionality and declare the tax null and void? In other words, is the constitutionality of the act of such a nature that the courts can afford judicial relief? For it must be borne in mind that there are plenty of instances in our constitutional system in which the Supreme Court is powerless to prevent even the flagrant violation of our fundamental law. ${ }^{96}$ Does the use by Congress of a constitutional power for an unconstitutional purpose create a case in which the remedy for unconstitutional action must be political rather than judicial?

Consideration of this problem may well begin with an examination of the case of McCray $v$. United States, ${ }^{97}$ in which in 1904 the Supreme Court sustained the validity of the oleomargarine tax of 1902. It was urged upon the court in this case that the tax of ten cents per pound upon colored oleomargarine was not designed to raise revenue but to suppress the manufacture of the article taxed. Everyone knew of course, that this was true. Such a tax was alleged to be unconstitutional because it amounted to an invasion of the reserved power of the states, because it was not in itself a legitimate means of exercising the taxing power, because of its destructive nature, and because it amounted to a deprivation of liberty and property rights which no free government might destroy.

The opinion of Mr. Justice White in the McCray case declared, first, that the court could not inquire into the motives

95 Infra, p. 275.

96 These instances are those in which the Court faces what it has called "political questions." See Black, op. cit.. 100, Cooley, Principles, 157. Hall. op. cit.. 40. Willoughby, op. cit., II. 999.

97 (1904) 195 U. S. 27,24 S. C. R. 769,49 L. Ed. 78, 1 Ann. Cas. 561. 
which actuated a particular exercise of an admitted power of Congress. This is, of course, familiar doctrine. ${ }^{98}$

"No instance is afforded," said the court, "from the foundation of the government where an act which was within a power conferred, was declared to be repugnant to the constitution, because it appeared to the judicial mind that the particular exertion of constitutional power was either unwise or unjust. . .

"It is, however, argued if a lawful power may be exerted for an unlawful purpose, and thus, by abusing the power, it may be made to accomplish a result not intended by the constitution, all limitations of power must disappear, and the grave functions lodged in the judiciary, to confine all the departments within the authority conferred by the constitution, will be of no avail. This, when reduced to its last analysis, comes to this: that because a particular department of the government may exert its lawful powers with the object or motive of reaching an end not justified, therefore it becomes the duty of the judiciary to restrain the exercise of a lawful power wherever it seems to the judicial mind that such lawful power has been abused. But this reduces itself to the contention that, under our constitutional system, the abuse of one department of the government of its lawful powers is to be corrected by the abuse of its powers by another department."

In the second place, the court refused to invalidate the act on the ground that the results of the law, irrespective of its form or the motives of its framers, were such as to indicate an unconstitutional use of the taxing power. The court said:

"Undoubtedly, in determining whether a particular act is within a granted power, its scope and effect is to be considered. Applying this rule to the acts assailed, it is self-evident that on their face they levy an excise tax. That being their necessary scope and operation, it follows that the acts are within the grant of power. The argument to the contrary rests on the proposition that, although the tax be within the power, as enforcing it will destroy or restrict the manufacture of artificially colored oleomargarine, therefore the power to levy the tax did not obtain. This, however, is but to say that the question of power depends, not on the authority conferred by the constitution, but upon what may be the consequence arising from the exercise of the lawful authority."

The upshot of the McCray case, then, seems to be that the Supreme Court will not invalidate any congressional act which "on its face" levies a tax, no matter what the motive or results

${ }^{98}$ Black, op. cit., 69; Cooley, Constitutional Limitations, 257; Story, op. cit., II, sec. 1090 ; Willoughby, op. cit., I. 18 ; United States v. Des Moines Nav. \& R. Co., (1891) 142 U. S. 510. 544, 35 L. Ed. 1099, 12 S. C. R. 308; Weber v. Freed, (1915) 239 U. S. 325, 330, 60 L. Ed. 308, 310, 36 S. C. R. 311. Ann. Cas. 1916C 317: Dakota Cent. Teleph. Co. v. South Dakota, (1919) 250 U. S. 163, 194, 63 L. Ed. 910, 924, 39 S. C. R. 507. 
of that act may be. This is all that the case actually decided. The court suggests by way of dictum that there may be attempts by Congress to exercise the taxing power which are not "on their face" acts of taxation and which not only amount to "an abuse of delegated power, but the exercise of an authority not conferred." But.it seems clear that what Mr. Justice White had in mind was the possibility of the use by Congress of its taxing power for the destruction of fundamental private rights. ${ }^{99}$

This raises the interesting question, when, if ever, does a law purporting to be an exercise by Congress of its power to tax cease to be a tax "on its face," so as to justify the court in declaring it null and void. ${ }^{100}$ The answer to this question is not to be found in Mr. Justice White's opinion in the McCray case, but some light upon the meaning which he attached to the phrase "on its face" may be gleaned from a further perusal of his remarks in the United States Senate while he was a member of that body.

In the first place, it is apparent from the statements of Senator White that a law purporting to be a tax law does not in his judgment necessarily cease to be a tax "on its face" and thereby fall under the judicial ban even when as a member of Congress he would be obliged to vote against the bill as unconstitutional because he knows the purpose of the tax to be not revenue but prohibition or regulation. ${ }^{101} \mathrm{He}$ cannot necessarily know and act upon as a judge the things which he knows as a legislator.

"It is perfectly self-evident when a bill, which is a revenue bill, comes to me for consideration, as to whether I will vote for it or not, it may be to me-if I may be allowed to use the word, a philosophical word-subjectively unconstitutional per se, and I may not vote for it as constitutional, because I know that, although it is a revenue bill, there is a purpose of destruction and prohibition contained in it. But when it comes to the court, the court can only look at it objectively. The court must look at its provisions, and if on its face it is a revenue bill, if on its face it be for the purpose of raising revenue, the court will say that it cannot consider the motive, but must decree its enforcement. . . .

${ }^{98}$ For the full context see note 93 , supra.

$100 \mathrm{It}$ is interesting to note that Cooley also uses this phrase "on its face" in discussing the validity of taxing acts. He says: Practically, therefore, a law purporting to levy taxes, and not being on its face subject to objection, is unassailable, whatever may have been the real purpose." Principles of Constitutional Law, p. 58.

$101 \mathrm{It}$ is clear, of course, that Senator White adhered to this narrower view of the proper purposes of federal taxation. Supra, p. 264. 
"If I were the Executive or a judge and the bill came to me, then having passed out of this sphere and into another sphere where motives could not enter, I should say the sole question presented to me was, does it raise revenue on its face, and if so, I would hold it constitutional."102

But in the second place, if a judge is convinced from a study, not of the congressional debates, but of the provisions of the taxing measure itself, that it cannot in practical effect raise any revenue, but must of necessity result in regulation or destruction of things outside congressional authority, he may then conclude that it is not a tax law "on its face" and may hold it unconstitutional. This was Senator White's attitude toward the destructive taxes proposed to be levied upon cotton and grain futures. He declared that:

"On the very face of the bill not even a pretext of taxation can be found. By the very terms of the bill no tax can result from its provisions.

"It is perfectly true that in two or three cases the Supreme Court of the United States has said that where on the face of a statute there was the exercise of taxation, as the statute was on its face a taxing statute, the court would not destroy the face of the statute with the sponge of the motives which may have actuated the members who passed it. Is that the case here? Where the face of the statute shows no tax, where the face of the statute itself eliminates all human possibility of the exercise of the taxing power for revenue, then I say the mission of jurisdiction is given to the courts of this land to brush that statute away for its flagrant and open violation of the constitution.

If the usurpation is clear on the face of the act, if the act itself shows the usurpation, the power exists in the Supreme Court to prevent the usurpation." 103

In short, when the court concludes from a scrutiny of the act itself that the act cannot in effect produce revenue, it need not

102 Cong. Rec., July 21, 1892, Vol. 23, 6518-6519.

Compare with this the following statement by President Cleveland in his message accompanying his approval of the Oleomargarine Tax Act of 1886: "It has been urged as an objection to this measure that while purporting to be legislation for revenue its real purpose is to destroy, by the use of the taxing power, one industry of our people for the protection and benefit of another.

"If entitled to indulge in such a suspicion as a basis of official action in this case, and if entirely satisfied that the consequences indicated would ensue, I should doubtless feel constrained to interpose executive dissent.

"But I do not feel called upon to interpret the motives of Congress otherwise than by the apparent character of the bill which has been presented to me, and I am convinced that the taxes which it creates cannot possibly destroy the open and legitimate manufacture and sale of the thing upon which it is levied." Richardson. Messages and Papers of the President, VIII, 427.

${ }^{103}$ Cong. Rec.. July 21, 1892, Vol. 23, 6516. 
hesitate, according to Senator White, to declare that Congress has tried to wield an authority which it does not possess and that such an exercise of the taxing power is "objectively" unconstitutional. ${ }^{104}$

Senator White's standard for judging the objective constitutionality of a congressional use of the taxing power has much more than an academic interest, first because his present position as Chief Justice of the United States gives him an opportunity to apply it or urge its application in the forthcoming decision on the validity of the child labor tax, and also because he has already had one opportunity to apply it, namely, in the McCray case, and it is therefore possible to observe its nature and limitations. The fact that the oleomargarine tax of 1902 was under the circumstances found objectively constitutional throws some light upon the true value of Senator White's test as a check upon the use of the federal taxing power for police purposes. In commenting in the Senate in 1892 upon the oleomargarine tax of 1886 , Senator White declared that when this measure was introduced into Congress it provided for a "prohibitive tax" but that in spite of the pressure for its passage it was too much for the "constitutional stomachs" of some of the members and it was accordingly reduced to a revenue-producing capacity. ${ }^{105}$ The implication is perfectly clear that Senator White regarded this "prohibitive" tax as one which was objectively unconstitutional; while the tax in its reduced form was objectively constitutional. Now this objectively unconstitutional tax on oleomargarine was a tax of ten cents per pound. In 1904, however, when as associate justice of the Supreme Court, Mr. White wrote the opinion in

104 "Now let us reason out the consequences, if it be not true. If this be not true, then the beautiful system by which, as I said just now, all the departments of the government move in a common orbit, vanishes out of the sidereal universe of government and passes into confusion and chaos. The precedents are against it. The power which the Supreme Court of the United States exercises in the review of statutes is like unto the power exercised by the supreme courts of all the states. The books are full of cases in the state courts drawing the distinction which I have made. In the Topeka case it is drawn in plain words by the Supreme Court of the United States. There a government appropriated a sum of money, declaring it to be for a public purpose. The case went to the Supreme Court of the United States and it said your motive and your purpose cannot be inquired into. That is removed beyond the domain of controversy or question. But where you have called the statute one thing and the very terms of the statute indicate another thing, and that other thing is outside the powers of government, then it is not a statute at all, but it is a violation of authority and we strike it from the statute books." Cong. Rec.. July 21, 1897, Vol. 23, 6516.

${ }^{105}$ Cong. Rec., July 21, 1892, Vol. 23, 6518. 
the McCray' case, the same tax of ten cents per pound on colored oleomargarine seemed to him "on its face" to be a revenue measure and therefore objectively constitutional. A tax objectively unconstitutional in 1886 turns out to be objectively constitutional in 1904. ${ }^{106}$ One is forced to the conclusion that he found as justice of the Supreme Court insurmountable difficulties in the way of declaring "objectively unconstitutional" a taxing statute which as a legislator he had felt convinced should fall under the judicial ban.

It is not at all surprising that the Supreme Court, even had it been unanimously inclined to do so, should have found it exceedingly difficult to declare unconstitutional a law purporting to be an exercise by Congress of its delegated power of taxation because it did not "on its face" levy a tax. In addition to the general presumption of constitutionality which attaches to any act of the legislature there is added, unless Congress is unusually careless, the presumption arising from the legislative label declaring the act to be for the raising of revenue. ${ }^{107}$ It is riecessary also for the court to give full weight to the unquestioned freedom of Congress to select the subjects of lawful taxation, ${ }^{108}$ and, having selected them, to impose rates which are restricted only by legislative discretion. ${ }^{109}$ The court must also exercise sufficient self-control to rule out of consideration all that it may know about the purposes and motives actuating the legislators responsible for passing the law. ${ }^{110}$ It is not at liberty to decide

106 There is a theory on which the Act of 1886 can be distinguished from the Act of 1902. The earlier law levied a uniform tax upon all oleomargarine. The Act of 1902 levied a tax of one-quarter of a cent per pound on uncolored oleomargarine and a tax of ten cents per pound on that which was colored. It was argued in Congress that the destructive tax upon the colored product was to aid the government in the enforcement of the revenue-producing tax on the uncolored product by preventing a deception which would facilitate tax evasion. See remarks of Senator Hoar, Cong. Rec.. Mar. 26, 1902, Vol. 35, 3282, and of Senator Spooner, ibid 3506. This is the theory upon which the Supreme Court upheld the Harrison Anti-Narcotic Act in the recent case of the United States r. Doremus, (1919) 249 U.S. 86, 63 L. Ed.-, 39 S. C. R. 214. There is no evidence, however, that Mr. Justice White attached any significance to this point when writing his opinion in the McCray case.

${ }_{107}$ The entire statute was entitled "An Act to Provide Revenue and For Other Purposes;" the section relating to child labor was entitled "Tax on the Employment of Child Labor."

108 Treat v. White, (1900) 181 U. S. 264, 45 L. Ed. 853, 21 S. C. R. 611 ; Patton v. Brady, (1902) 184 U. S. 608, 46 L. Fd. 713, 22 S. C. R. 493. See Cooley, Principles, p. 57 ; Cooley, Taxation, I, 179-180.

${ }^{109}$ Marshall established this doctrine in McCulloch v. Maryland. Knowlton v. Moore, (1900) 187 U. S. 41, 58, 20 S. C. R. 747, 44 L. Ed. 969. ${ }_{110}$ See note 98 , supra. 
whether or not "on its face" the act raises revenue by finding out whether or not, when set in operation, it actually does raise any revenue. ${ }^{111}$ Probably in most cases also such evidence would be lacking at the time the court needed it, ${ }^{112}$ and such evidence might be of very questionable reliability as a guide to the court. $^{113}$ If the court is able thus to orient itself sufficiently and to bring to bear on its problem the mental complex which should result from the considerations above noted, it must then address itself to the problem whether the provisions of the statute which it is scrutinizing are, in and of themselves, of such a character as to leave no reasonable doubt that the act is not an act to raise revenue. To make this judicial guess as to what the statute was probably meant to accomplish and what it probably will accomplish, the court must deal with factors which are not only highly speculative in character but have an awkward tendency to fluctuate. Whether an alleged revenue law may be reasonably presumed to produce revenue will depend upon circumstances, and circumstances may change. The measure of constitutionality might thus tend to shift. ${ }^{114}$ In short, in applying this test of objective unconstitutionality, the court will properly feel that it must be more than usually sure of its ground in respect to a

111 See paragraph quoted from Mr. Justice White's opinion in the Mc.Cray case, note 93 supra.

112 As when the question of the validity of the taxing act is raised in an action seeking an injunction to restrain enforcement. This was the nature of the proceeding in the United States district court in which the child labor tax has been held invalid. Supra, note 11. The court might be compelled to determine this question before the law had been fairly put into operation.

113 It is, of course, well known that even fiscal experts are frequently deceived as to the actual revenue-bearing capacity of a particular tax. Furthermore, interested parties might secure the payment for a temporary period even of prohibitive taxes in order to provide evidence of the ability of the tax to produce some revenue.

114 This was pointed out in humorous fashion by Mr. Hepburn in the debate in the House on the oleomargarine tax of 1886: "In the year 1887, when the effect of the bill, we will suppose, is to prohibit the manufacture of oleomargarine, the bill becomes unconstitutional. But suppose the next year on account of the withdrawal of $200,000,000$ pounds of this spurious butter that is sold, and used as butter, leaving on the market $1,000,000$ pounds of good butter, the price of butter is enhanced, going up to $25 \mathrm{c}$ or $30 \mathrm{c}$ a pound. The manufacturer of the bogus article can then compete, if he can make the article and pay the tax, so that there will be a revenue of $\$ 20,000,000$ to the government. Then the law becomes a constitutional measure! So that according to the gentleman's argument the bill may be constitutional in 1886, unconstitutional in 1887, and again become constitutional in 1888 . T he bill is not constitutional or unconstitutional because of the nature of the enactments that it contains, but because of the price of butter!" (Laughter.) Cong. Rec., Vol. 17, 4901. 
problem so vague and baffling in character that sureness of ground will frequently be well nigh unattainable.

The writer ventures the opinion that should the majority of the Supreme Court adopt either the revenue only theory of federal taxation or Chief Justice White's theory that the purposes for which Congress may tax are limited by the reserved powers of the states, it would find the problem of applying any satisfactory test of objective constitutionality for the purpose of enforcing such limitations so fraught with difficulties that those limitations would practically cease to function. Congress would find itself possessed in reality of practically the same broad powers of taxation which the states and other sovereign governments enjoy. Such power would continue to be subject to all the express limitations found in the constitution; it would be subject to the implied limitation that the revenue raised must be for a public purpose; it would be subject to the implied limitation that it must not burden the governments or functions of the states; it would be subject to the implied limitation that it must not infringe the individual rights which under a free government are inviolable. It seems exceedingly doubtful that any instance will arise in which a law passed by Congress in exercise of its power to tax which was safely within all these express and implied restrictions will be declared null and void by the Supreme Court because "on its face" it does not "levy a tax." If Senator White's standard of objective constitutionality failed to function in the McCray case, it is not easy to imagine the kind of taxing statute to which it would apply. If it was inapplicable to the oleomargarine tax of 1902 it is hard to discover its applicability to the child labor tax of 1919.

By way of summary and conclusion it may be suggested that the nature of the purposes for which Congress may properly use its power to tax is a question on which there is now and has always been a wide difference of opinion. There is plenty of respectable authority for the support of each one of the three views discussed. It may be noted that Congress has proceeded upon the theory that it may use its power to tax for the accomplishment of any purposes which will aid the common defense and general welfare. It is apparent that the Supreme Court has never put its official sanction upon any one of the three theories of federal taxation to the exclusion of the others. It seems probable that the narrower and more restricted conceptions of 
the taxing power would, from the standpoint of the practical problem of judicial construction, prove incapable of satisfactory enforcement. There is every indication that Congress, if it is sufficiently circumspect, may continue to exercise a liberal police power through the medium of regulatory and destructive taxes without fear of judicial interference.

But if the child labor tax is upheld, either because the Supreme Court decides upon broad grounds that the law is constitutional or because it finds its unconstitutionality inaccessible, Congress will be justified in feeling that it has been substantially fortified in its position that it may use its power to tax as an instrumentality for the exercise of a broad national police power. It will be reasonable to look for further and more farreaching measures seeking by means of taxation to regulate conditions and suppress evils over which Congress has no direct authority.*

*This series of articles will be concluded by an article, "The National Police Power under the Postal Power." 


\section{NATIONAL POLICE POWER UNDER THE POSTAL CLAUSE OF THE CONSTITUTION}

IF ONE were asked to explain and illustrate the doctrine of implied powers as it has functioned in the development of our constitutional law, there would probably be no easier way to do it than to point to the enormous expansion of the postal power of Congress. ${ }^{1}$ The clause in the federal constitution which grants to Congress the power "to establish Post Offices and Post Roads" was inserted there almost without discussion. ${ }^{3}$ It seems to have appeared entirely innocuous even to the most suspicious and skeptical of those who feared that the new government would dangerously expand its powers at the expense of the states and the individual. ${ }^{4}$ And yet that government had hardly been set in operation before this brief grant of authority began to be subjected to a liberal and expansive construction under which our postal system has come to be our most picturesque symbol of the length and breadth and strength of national authority. ${ }^{5}$

1 The subject of the expansion of the postal power of Congress has been fully treated in a very excellent monograph by Lindsay Rogers entitled "The Postal Power of Congress," Johns Hopkins University Studies in Historical and Political Science, 1916. The writer has drawn freely upon Professor Rogers' researches in the preparation of this article.

2 Art. I, Sec. 8, Cl. 7.

${ }^{3}$ In its present form it was not debated at all. In the New Jersey Plan introduced into the Convention by Paterson on June 15 it was proposed to allow Congress to raise revenue, among other ways, "by a postage on all letters or packages passing through the general Post Office." Farrand, Records of the Federal Convention, I, 243. The history of the postal clause in the convention is traced in Rogers, op. cit., 23. It throws no light on the present problem.

4 Madison, in the 42nd number of the Federalist, dismissed the subject with the statement, "The power of establishing post roads, must, in every view, be a harmless power; and may, perhaps, by judicious management, become productive of great conveniency."

5 "Under that six-word grant of power the great postal system of this country has been built up, involving an annual revenue and expenditure of over five hundred millions of dollars, the maintenance of 60,000 post offices, with hundreds of thousands of employees, the carriage of more than fifteen billions of pieces of mail matter per year, weighing over two billions of pounds, the incorporation of railroads, the establishment of the rural free delivery system, the money order system, by which more than half a billion of dollars a year is transmitted from person to person, the postal savings bank, the parcel post. an aeroplane mail service, the suppression of lotteries, and a most efficient suppression of fraudulent and 
This expansion of national authority under the postal power given to Congress has proceeded along two distinct but related lines. There has been, in the first place, a striking expansion of what may be called the collectivist or socialistic functions carried on through the post office. ${ }^{6}$ Here may be mentioned such enterprises as the postal money order system, the postal savings bank, the parcel post, and the use of the post office as an agency of publicity to aid in the marketing of farm products and in solving the problem of unemployment. In some countries, of course, the scope of the collectivist functions delegated to the post office is much broader than in the United States; but it seems highly probable that the American postal system has by no means reached the limit of its growth as an agency for positive service to the people. ${ }^{7}$ This interesting subject is not, however, the one under consideration in this article. In the second place, national authority under the postal power has developed in striking measure along the line of repression and regulation effected by the denial or forfeiture of postal privileges. Acting on the theory that the hand which bestows privileges may also withhold them, Congress has wielded the power of exclusion from the mails with a vigorous arm. It has refused to carry in the mails a long list of articles injurious in themselves or destined for injurious uses, has denied the use of postal privileges in aid of fraudulent transactions, and has seriously contemplated at times denying entirely all mail privileges as a penalty for certain acts on the part of the corporation or the individual which it would have no direct authority to punish. Congress has in this way generously extended the scope of its authority over many subjects which the framers of the constitution undoubtedly assumed they had

criminal schemes, impossible to be reached in any other way." Read into the opinion of the Supreme Court from the brief for the government in Lewis Publishing Co. v. Morgan (1912) 229 U. S. 288, 57 L. Ed. 1190, 33 S. C. R. 867.

Rogers, op cit., 33.

7 Possible expansion of postal functions is suggested by the types of service rendered by the post office during the war as fiscal agent for the government through the handling of IVar Savings Stamps as well as other miscellaneous activities. The war-time control of the telegraph and telephone systems by the postmaster general was effected as an exercisc of the war power, and no apparent effort was made to correlate the activities of those systems with those of the post office, as is done in some European countries. Whether Congress could, merely as an exercise of the postal power, acquire all the telegraph lines is a question which was referred to but left open by the Supreme Court in the case of Pensacola Telegraph Co. v. Western Union Telegraph Co., (1877) 96 U. S. 1. 24 L. Ed. 708. 
succeeded in leaving to the exclusive jurisdiction of the states. In short, the national government has managed to make the seemingly matter-of-fact and innocent grant of authority to establish post offices and post roads serve as a "constitutional peg" upon which to hang a very substantial federal police power which may be employed to regulate and protect the national safety, good order, and morals. The postal power, therefore, forms a very important adjunct to the power to regulate commerce, ${ }^{8}$ and to tax, ${ }^{9}$ the three powers building up both by direction and indirection what, for want of a better term, may be called the police power of the national government. It is the purpose of this article to trace the various lines along which this national police power has developed under the postal clause of the constitution, to examine the conflicting views regarding the constitutional propriety of that development, and to determine, if possible, what are the true limits of the police power so derived.

The problem under consideration may be conveniently treated under four principal topics: (1) First, there are police regulations which Congress has enacted to protect the safety and efficiency of the postal system. Here may be placed such laws as those excluding poisons and explosives from the mails. (2) Second, there are those police regulations enacted to prevent the postal system from being used for purposes which are injurious to the public welfare or to encourage such uses of the postal system as are beneficial to the public welfare. The fraud order legislation and the obscene literature acts will fall into this group. (3) Third, may be mentioned those regulations which deny the right to use the mails for the purpose of violating or evading the laws of the states. The act forbidding the mailing of liquor advertisements into prohibition states exemplifies this type of statute. (4) Finally, there are proposals that conformity to general police regulations be made the price of the enjoyment of postal privileges. Here would be classed the recent proposal to deny the privileges of the United States mails to all persons employing child labor. Each of these types of police regulation under the postal power may be briefly examined.

\footnotetext{
8 See Cushman, The National Police Power under the Commerce Clause of the Constitution, (1919) 3 Mixisesota Law Review 289, 381. 452.

9 See Cushman. The National Police Power under the Taxing Clause of the Constitution, (1920) + Mrsiesota Law Review 247.
} 


\section{Police Regulations to Protect the Safety and EFficiency of THE MaILs}

The right of Congress to pass such laws as are reasonably designed to protect the safety and efficiency of the postal system has at no time been seriously questioned, and is at present not questioned at all. Congress has been expressly granted the power to establish post offices; and it would be ridiculous to allege that the power to establish a governmental agency did not of necessity carry with it the power to preserve and protect it when once established. ${ }^{10}$ Congress has, in fact, exercised such power ever since our national postal system was created. The most obvious and natural form of postal protection has been, of course, the enactment of laws punishing various acts which are criminal in themselves. Some twenty sections of the United States Criminal Code $^{11}$ are devoted to such offenses as robbing, destroying, or obstructing the mails, injuring mail property, counterfeiting money orders and stamps, or in any way defrauding the post office. $^{12}$ But a consideration of these measures would not properly be included in a discussion of the national police power ${ }^{13}$ even if they raised, as they do not, any interesting or important questions of constitutional, construction. There are, however, two types of legislation which Congress has passed for protecting the mail service and promoting its efficiency which may be classified as police regulations and upon which brief comment may be made. The first comprises the enactments designed to make the postal service a government monopoly; the second includes the laws excluding from the mails things which would imperil or

10 In developing his doctrine of implied powers Marshall used what he thought must be regarded as an entirely obvious illustration, the right of Congress to protect the post office. He said: "Take, for example the power to establish post offices and post roads. This power is executed by the single act of making the establishment. But from this has been inferred the power and duty of carrying the mail along the post road and from one post office to another. And, from this implied power, has again been inferred the right to punish those who steal letters from the post office, or rob the mail. It may be said, with some platusibility. that the right to carry the mail, and to punish those who rob it, is not indispensably necessary to the establishment of a post office and post road. This right is, indeed, essential to the beneficial exercise of the power. but not indispensably necessary to its existence." McCulloch " $:$ Maryland, (1819) 4 Wheat. (U.S.) 316, 4 L. Ed. 579.

11 Act of March 4, 1909, 35 Stat. at L. 1088.

12 Ibid, Secs. 189-202, 205, 218-221, 227-228.

13 The enactment of ordinary criminal statutes is usualiy classified as an exercise of power outside the scope of the police power. See Freund, Police Power, Secs. 4-8. 
injure the mails themselves, or postal property, or postal employees.

1. Regulations to Insure Postal Monopolv. The national postal system was made a government monopoly in $1792^{14}$ and has remained so ever since. ${ }^{15}$ Although the grant of postal power to Congress did not by its terms create a government monopoly and although there is judicial authority for the view that the monopolistic character of the postal system results not from the postal clause but from the legislation enacted under it, ${ }^{16}$ there would seem to be some reason to believe that the framers of the constitution expected that the new post office would become a monopoly in the hands of the government. There was plenty of precedent as well as public policy ${ }^{17}$ to support such a principle. The British post office had long been a government monopoly ${ }^{18}$ and Blackstone had emphasized the paramount necessity for such .exclusive control. ${ }^{19}$ Thus while many questions have from time to time arisen as to the correct interpretation to be placed upon the acts of Congress penalizing the private carrying of the mails, ${ }^{20}$ there has been no serious attack made upon the constitutional right of Congress to pass those laws. ${ }^{21}$ The recent action

14 Act of Feb. 20, 1792, 1 Stat. at L. 232. In 1782 the Congress of the Confederation had passed "An Ordinance for Regulating the Post Office of the United States of America." By one of the provisions of this Ordinance, Congress attempted to create and maintain a postal monopoly. 7 Journals of Congress 383. For summary of this entire act, see Rogers, op. cit.. 17 ff.

15 United States Criminal Code, Act of March 4, 1909, 35 Stat. at L. 1088, Secs. 179, 181, 186.

16 "But the monopoly of the government is an optional, not an essential part of its postal system. The mere existence of a postal department of the government is not an establishment of the monopoly." United States v. Kochersperger, (1860) Fed. Cas. No. 15,541.

17 "The post office monopoly is primarily an institution for the public benefit which must exclude competition from its profitable business in order to carry on the unprofitable business," Freund, Police Power, Sec. 666. If the post office were to be used as a means of raising revenue as suggested in the Convention of 1787 (supra, note 3 ), another ground for monopoly would exist.

${ }_{18}$ The development of the British Post Office as a government monopoly is traced at length by Hemmeon, The History of the British Post Office, Ch. IX.

19 "Penalties were enacted in order to confine the carriage of letters to the public office only, except in some few cases: a provision which is absolutely necessary; for nothing but an exclusive right can support an office of this sort: many rival independent offices would only serve to ruin one another." Cooley's Blackstone, I, 323.

20 Rogers, op. cit., 41 ff.

21 "To give efficiency to its regulations ard prevent rival postal systems, it may perhaps prohibit the carriage by others for hire, over postal routes, of articles which legitimately constitute mail matter. . "Ex 
of the federal authorities to prevent under the terms of the Criminal Code the transportation of telegraphic night letters by train instead of by wire, indicates that the statutes under consideration are adequate to cope with new and unusual forms of competition against the United States mails. ${ }^{22}$

2. Exclusion of Articles Injurious to the Postal Service. If Congress in the exercise of its power to regulate interstate commerce may exclude from that commerce commodities which would endanger or injure the agencies by which it is carried on ${ }^{23}$ then, a fortiori, it must follow that Congress may provide similar protection to a postal system which it not merely regulates but establishes and conducts. While it is highly desirable that Congress should require that adequate safety devices should be installed on interstate trains and that reasonable regulations be complied with in transporting explosives or other dangerous materials, the fact remains that the federal government itself does not serve as a common carrier and its responsibility for the physical safety of interstate commerce is, perhaps, a secondary responsibility. ${ }^{24}$ The public which rides or which ships goods in interstate commerce would be loath to part with the protection guaranteed by federal laws; but their plight, were that protection removed, would be no different from that of the patrons of the wholly intrastate carriers which are not subject to federal authority. With the postal service, however, the case is very different. In respect to it Congress must assume a very definite and primary responsibility. In fact, there are at least four cogent reasons for the congressional exclusion of dangerous and injurious articles from the mails which do not apply to the exclusion of similar commodities from the channels of interstate commerce. In the first place, Congress has a proprietary interest in the postal system which it does not have in interstate commerce. In passing the laws in question Congress is but taking reasonable precautions for the protection of the property of the federal government. 'In the second place, in conducting its mail

parte Jackson, (1877) 96 U. S. 727, 735, 24 L. Ed. 877; United States v. Bromley, (1851) 12 How. (U.S.) 87, 13 L. Ed. 905: United States $r$ Thompson, (1846) 9 Law Rep. 451, Fed. Cas. No. 16,489.

22 New York Times, June 21, 1918.

${ }_{23}$ Cushman, op. cit., 3 Minnesota Law Review 303.

24 Persons sustaining loss by reason of the negligence of interstate carriers would, of course, have a right of action against the carrier to recover damages even in the absence of any statutory regulations insuring the safety of interstate commerce. 
service the federal government offers itself as a carrier of other people's property. Letters and property are confided to its possession and control; indeed the laws, as has been seen ${ }^{25}$ forbid all persons to confide mail matter to any one but the postal authorities. It follows, therefore, that the government must take every reasonable precaution to insure the safety of the property it not only permits but virtually requires to be confided to its care. If it fails to guarantee such safety there is no one else to whom the person who suffers the loss or injury of his property may look for reparation. In the third place, Congress should recognize a clear responsibility to provide adequately for the safety of its postal employees and to see that they are not exposed to avoidable dangers. Finally, since Congress has created the postal system and is the author and source of all postal privileges, the exercise of the power to deny those privileges to dangerous or injurious articles could not be attacked, as the congressional exclusions from interstate commerce have sometimes been attacked, on the ground that Congress is denying a right or privilege which it did not create and which it has the authority merely to regulate and not to destroy. ${ }^{26}$

Enough has been said to indicate that there can be no question of the constitutional power of Congress to exclude dangerous and injurious articles from the mails. It is not only the right of Congress to pass such legislation but it is also its duty. This duty has been fulfilled by the insertion into the Criminal Code of a substantial list of articles which are declared non-mailable because of their injurious character, ${ }^{27}$ and by the delegation to the postmaster general of the authority to expand that list. ${ }^{28}$ Not only has the validity of this legislation never been questioned, but the courts have not infrequently alluded to these laws as examples of the legitimate exercise of the postal power delegated to Congress. ${ }^{29}$ Needless to say, this is a type of legislation which

25 Supra. p. 406.

${ }^{26}$ For discussion of this distinction see infra, p. 423.

27 United States Criminal Code, Sec. 217, Act of March 4, 1909, 35 Stat. at L. 1131.

28 United States Official Postal Guide, 1918, p. 19.

29 "It [Congress] may also refuse to include in its mails such printed matter or merchandise as may seem objectionable to it upon the ground of public policy, as dangerous to its employees or injurious to other mail matter carried in the same packages. The postal regulations of this country issued in pursuance of act of Congress contain a long list of prohibited articles dangerous in their nature, or to other articles with which they may come in contact, such, for instance, as liquids, poisons, explosives and 
other countries have also enacted in order to provide adequate protection to their mails. ${ }^{30}$

\section{Classifications of Mailjing Privileges to Prevent Harmful and to Encourage Beñeficial \\ Uses of Postal System}

It requires no argument to prove that the vast postal system of the United States, rendering as it does its many varieties of service and reaching practically every home, is an instrumentality for promoting and spreading civilization and culture. It is an enormous agency for good. The characteristics which make it an agency for good, however, also make it an agency for evil unless measures are taken to prevent its misuse. To prevent the postal service from being used as a conduit for dumping injurious and harmful matter into millions of homes, and to keep it from serving as a means of consummating fraudulent and unlawful acts, Congress has passed a substantial body of legislation: These laws are manifestly designed.for the protection of the public and not of the postal service itself. They are designed to protect the public from the misuse of the mails. They are unmistakably police regulations for they aim squarely at the protection of the public health, morals, safety, and good order. This legislation may be briefly analyzed and described before an examination of its constitutional basis and limits is entered upon.

1. Obscene Literature. Since the regulation of private morals is by the division of power between the nation and the states left to the latter, there was, of course, no reason why Congress should concern itself with the problem of obscene literature until it became clear that the mails or the channels of commerce were being used as a means of circulating the obnoxious matter. Federal legislation relating to obscene literature began with the Tariff of 1842 , a provision of which forbade the importation into this country of obscene literature or pictures. ${ }^{31}$

inflammable articles, fatty substances, or live or dead animals, and substances which exhale a bad odor. It has never been supposed that the exclusion of these articles denied to their owners any of their constitutional rights." Public Clearing House v. Coyne, (1903) 194 U. S. 497, 48 L. Ed. 1092, 24 S. C. R. 789.

${ }^{30}$ For summary of articles, which, under the laws of foreign countries. may not be sent through the mails into such countries, see U. S. Official Postal Guide, 1919, 137 ff.

31 Act of Aug. 30, 1842, 5 Stat. at L. 562, Sec. 28. For the development of the policy of excluding obscene literature from interstate commerce see Cushman, op. cit., 3 Minnesota Law Review 388. 
It was not until 1865 that Congress took steps to exclude matter of this description from the mails $;^{32}$ and the first really effective legislation for this purpose seems to have been the Act of March $3,1873 .^{33}$ Various amendments to this law have been passed extending its scope and strengthening its provisions. ${ }^{34}$ At the present time there are two sections of the United States Criminal Code dealing with this subject. ${ }^{35}$ By the first of these provisions obscene and indecent writings, letters, pictures, or printed matter of any sort are declared to be unmailable as well as all contraceptive devices and information. ${ }^{36}$ Such matter may not be conveyed in the mails nor delivered by any post office employee. To deposit such matter in or to take it from the mails is made a criminal offense. The second provision makes non-mailable under severe penalties any mail matter on the outside cover of which is found any obscene, scurrilous, libelous, or defamatory inscriptions which would reflect injuriously upon the character or conduct of another. ${ }^{37}$ While the postal authorities are not permitted to receive or deliver mail matter known by them to be in violation of the provisions just described, they are rigidly forbidden to open sealed matter. ${ }^{38}$ While authority is given to exclude non-mailable matter, there is no power to prevent the subsequent circulation through the mails of later issues of the

32 Act of March 3, 1865, 13 Stat. at L. 507 . Amended June 8, 1872, 17 Stat. at L. 302.

3317 Stat. at L. 599.

34 Act of July 12,1876, 19 Stat. at L. 90; Act of Sept. 26, 1888, 25 Stat. at L. 496; Act of May 27, 1908, 35 Stat. at L. 416; Act of Mar. 4, 1911, 36 Stat. at L. 1339.

${ }^{35}$ Secs. 211, 212, Act of March 4, 1909, 35 Stat. at L. 1129.

36 "And the term 'indecent' within the intendment of this section shall include matter of a character tending to incite arson, murder, or assassination." Sec. 211, U. S. Criminal Code. The prohibitions of the act have been construed as applicable to the veiled advertisements of prostitutes. United States v. Dunlop, (1897) 165 U. S. 486, 41 L. Ed. 799, 17 S. C. R. 375.

${ }^{3 \pi}$ This provision is applicable to the sending of threatening or dunning inscriptions on packages or cards. United States v. Smith, (1895) 69 Fed. 971; United States v. Davis, (1889) 38 Fed. 326; United States v. Elliott, (1892) 51 Fed. 807 ; United States v. Simmons, (1894) 61 Fed. 640.

38 The inviolability of sealed mail matter from government invasion is guaranteed by the fourth amendment to the United States constitution which provides, "The right of the people to be secure in their persons, houses, papers, and effects, against unreasonable searches and seizures shall not be violated. . . "No law of Congress can place in the hands of officials connected with the postal service any authority to invade the secrecy of letters and such sealed packages in the mail; and all regulations adopted as to mail matter of this kind must be in subordination to the great principle embodied in the Fourth Amendment of the Constitution." Ex parte Jackson, (1877) 96 U. S. 727, 733, 24 L. Ed. 877. 
excluded publication or to forbid the subsequent use of the mails to any persons who have violated these provisions. ${ }^{39}$

While some persons have appeared from time to time to question the constitutionality of the obscene literature acts ${ }^{40}$ and numerous petitions have been presented to Congress urging their repeal ostensibly on constitutional grounds, ${ }^{41}$ there has never been any substantial body of opinion to doubt the authority of Congress to.pass them. There has been a considerable number of cases in which these acts have been construed and interpreted ${ }^{42}$ and a number of the lower federal courts have declared them to be constitutional, ${ }^{43}$ but their validity has never been attacked before the Supreme Court. ${ }^{44}$

2. Lottery Tickets and Circulars. Although Congress as well as the state legislatures at first regarded the lottery as a legitimate method of public finance, ${ }^{45}$ public sentiment condemning the institution soon began to make itself felt. In 1827 Congress passed its last act authorizing a lottery ${ }^{46}$ and its first act hostile to lotteries. ${ }^{47}$ This latter statute, however, was not a serious blow to lottery enterprises since it merely provided:

39 The annual report of the postmaster general for 1914 comments upon the many requests which come to the post office department for action of this sort and points out the limitations upon the power of the department in respect thereto; p. 48.

40 Schroeder, Obscene Literature and Constitutional Law, passim. See also Free Speech Anthology, by the same author.

41 On February 26, 1878, Congressman Benjamin F. Butler (Mass.) presented to the House of Representatives a petition signed by 50,000 persons protesting against the Obscene Literature Acts and asking their amendment in such a manner "that they cannot be used to abridge the freedom of the press or of conscience, or to destroy the liberty and equality of the people before the law and departments of the government on acount of any religious, moral, political, medical or commercial grounds or pretexts whatsoever." Congressional Rec. Vol. VII, p. 1340. Sixty-three petitions similar in character were presented during the first

42 See Thomas, Non-mailable Matter, Cl. V: Rogers, op. cit., 48 ff.

43 United States v. Wilson, (1893) 58 Fed. 768; United States v. Warner, (1894) 59 Fed. 355.

43 Rogers, op. cit., 48 ff.

44 "For more than thirty years not only has the transmission of obscene matter been prohibited, but it has been made a crime, punishable by fine or imprisonment, for a person to deposit such matter in the mails. The constitutionality of this law, we believe, has never been attacked." Public Clearing House v. Coyne, (1903) 194 U. S. 497, 48 L. Ed. 1092. 24 S. C. R. 789. In an earlier opinion the Supreme Court referred to the Obscene Literature Act of 1873 with apparent approval and said, "All that Congress meant by this act was, that the mail should not be used to transport such corrupting publications and articles. . . ." Ex parte Jackson, (1877) 96 U. S. 727, 736, 24 L. Ed. 877.

45 For summary of this early legislation see Thomas, op. cit., Secs. 1-4.

46 Act of Feb. 22, 1827, 4 Stat. at L. 105. This act authotized the city of Washington to include the lands of Thomas Jefferson within its lottery schemes.

47 Act of March 2, 1827, 4 Stat. at L. 238. 
"That no postmaster or assistant postmaster shall act as agent for lottery offices or under any color of purchase, or otherwise, send lottery tickets; nor shall any postmaster receive free of postage or frank lottery schemes, circulars, or tickets."

This mild law, however, very definitely suggests the constitutional principle upon which our present vigorous anti-lottery statutes rest: namely, that Congress may refuse to lend its postal facilities or agents in furtherance of lottery enterprises. The next congressional attack on lotteries did not occur until 1868 , when an act was passed providing:

"That it shall not be lawful to deposit in a post office, to be sent by mail, any letters or circulars concerning lotteries, so-called gift concerts or similar enterprises, offering prizes of any kind on any pretext whatever." 48

This act, however, provided no adequate means of enforcement and proved ineffective. ${ }^{49}$ In 1872 an act was passed which made it unlawful to deposit in the mail or to send by mail any letters or circulars concerning illegal lotteries, socalled gift concerts, or other similar enterprises, and the postmaster general was authorized to issue a fraud order against any person who conducted a fraudulent lottery, gift

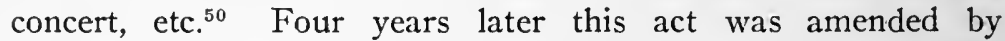
striking out the word "illegal" before lotteries and making the exclusion applicable to all lotteries whether forbidden by state law or not. ${ }^{51}$ The word "fraudulent" was retained, however, in the section relating to frand orders. ${ }^{52}$ In 1890 the law was amended so as to include lottery advertisements in newspapers within its prohibition and to eliminate the word "fraudulent" from the clause just mentioned. ${ }^{53}$ Under this legislation the postmaster general was authorized to prevent by the issuance of a fraud order the delivery of registered letters or the payment of money orders to persons known to be conducting lotteries or fraudulent schemes. By Act of 1895 the department was given power in such cases to withhold ordinary sealed mail matter as well as registered letters. ${ }^{54}$ The anti-lottery legislation has never

48. Act of July 27, 1868, 15 Stat. at L. 194.

49 There was no penalty provided for its violation and no appropriation to cover the cost of administration.

${ }^{50}$ Act of June 8, 1872, 17 Stat. at L. 283.

51 Act of July 12, 1876, 19 Stat. at L. 90.

52 This was construed to mean that a fraud order could be issued against only such lotteries as were actually fraudulent in character. Opinion of Attorney-General McVeagh, (1881) 17 Op. Atty. Gen. 77.

53 Act of Sept. 19, 1890, 26 Stat. at L. 465.

54 Act of March 2, 1895, 28 Stat. of L. 964. 
attempted to prohibit the operators of these enterprises from sending innocent matter through the mails.

While the constitutionality of this legislation has been bitterly attacked on various grounds, ${ }^{55}$ it has been sustained by numerous federal courts ${ }^{56}$ and by the United States Supreme Court in two important cases $^{57}$ the principles of which will be discussed at a later point in this article: $:^{58}$

3. Fraudulent Matter. The first attempt made by Congress to prevent the use of the mails for the circulation of correspondence relating to fraudulent schemes and enterprises was in $1872 .{ }^{59}$ This act subjected to severe penalty any person who devised any scheme or artifice to defraud.to be carried on by means of correspondence through the mails and who so used the mails in furtherance of such project. It authorized the postmaster general to withhold registered letters and payment on money orders from those who he had reason to believe were using the mails for the forbidden purposes mentioned. This law was expanded and strengthened by amendment in $1889^{\circ}$ by elaborating the list of schemes brought within the prohibition ${ }^{61}$ and by forbidding persons engaged in the proscribed enterprises to use the mails

${ }^{55}$ For a very able presentation of the case against this legislation see the argument of Mr. James C. Carter for the defendants in the case of In re Rapier, (1892) 143 U. S. 110, 113, 36 L. Ed. 90, 12 S. C. R. 353. See also brief for defendants in Ex parte Jackson, (1877) 96 U. S. 727, 24 L. Ed. 877. Also article by Mr. Hannis Taylor entitled, "A Blow at the Freedom of the Press," (1892) 155 North American Review 694. Mr. Taylor's attack is based largely on the fact that in the Lottery Act of 1890 the test of the immoral or injurious character of the matter excluded was not left to a jury but was determined by tests which Congress established in the act itself.

56 In re Jackson (1877) 14 Blatch. (U. S. C. C.) 245 , Fed. Cas. No. 7,124; New Orleans National Bank v. Merchant, (1884) 18 Fed. 841.

57 Ex parte Jackson, (1877) 96 U. S. 727, 24 L. Ed. 877; In re Rapier, (1892) 143 U. S. 110, 36 L. Ed. 90, 12 S. C. R. 353.

58 Infra, p. $419 \mathrm{ff}$.

59 Act of June 8, 1872, 17 Stat. at L. 283.

60 Act of March 2, 1889, 25 Stat. at L. 873 .

61 The prohibitions of the act were extended to apply to those who used the mails "to sell, dispose of, loan, exchange, alter, give away, or distribute, supply, or furnish, or procure for unlawful use, any counterfeit or spurious coin, bank notes, paper money, or any obligation or security of the United States or of any State, Territory, municipality, company, corporation, or person, or anything represented to be or intimated or held out to be such counterfeit or spurious articles, or any scheme or artifice to obtain money by or through correspondence by what is commonly called the 'sawdust swindle,' or 'counterfeit money fraud' or by dealing or pretending to deal in what is commonly called 'green articles; 'green coin,' 'bills,' 'paper goods,' spurious Treasury notes; 'United States goods,' 'green cigars,' or any other names or terms intended to be understood as relating to such counterfeit or spurious articles." 
under an assumed name. ${ }^{62}$ In 1895 the scope of the fraud orders issued was extended to include all first class mail. ${ }^{63}$ While post office officials have from time to time recommended the further amendment of the anti-fraud statutes to embrace within their provisions enterprises not now included, ${ }^{64}$ the present legislation has proved adequate to put an end to thousands of cheating and swindling schemes which had used the mails as the indispensable means of getting into touch with their victims. ${ }^{65}$

As in the case of the acts already examined, there has been a large amount of litigation over the construction of the antifraud acts and their applicability to specific schemes or enterprises. ${ }^{66}$ There have been attacks upon the constitutionality of the statutes on the ground of the procedure provided for the issuance of fraud orders and the courts have laid down certain rules respecting the scope and finality of the postmaster general's discretion in the matter. ${ }^{67}$ Both lower federal courts ${ }^{68}$ and the

$62 \mathrm{By}$ a section of this act, the postmaster general is authorized to require the personal identification of persons receiving mail matter when he has reason to believe that the names or addresses on such matter are fictitious.

${ }_{63}$ Act of March 2, 1895, 28 Stat. at L. 964.

64 The annual reports of the postmaster general in recent years have repeatedly urged the inclusion within the prohibitions of the law of all gambling devices or paraphernalia of any sort. For the text of this proposed legislation see Report of the Postmaster General for 1914, p. 81.

65 Data regarding the operation of the law is summarized yearly in greater or less detail in the report of the postmaster general. See report for 1918 , p. 58 .

${ }_{66}$ These questions are discussed in detail in Thomas, op. cit., Ch. IV. See also Rogers, op. cit., 56. It may be noted that schemes which may be included within the prohibitions of the act as "fraudulent" are not merely those which would be held fraudulent at common law as involving actual misrepresentation as to a past or existing fact, but extend to "everything designed to defraud by representations as to the past or present or suggestions and promises as to the future. . . It was with the purpose of protecting the public against all such intentional efforts to despoil and prevent the post office from being used to carry them into effect that this statute was passed; and it would strip it of its value to confine it to such cases as disclosed an actual misrepresentation as to some existing fact, and exclude those in which is only the allurement of a specious and glittering promise." Durland v. United States, (1896) 161 U. S. 306, 314, 40 L. Ed. 712,16 S. C. R. 508.

67 It has been held by the Supreme Court that the judgment of the postmaster general with reference to the issuance of fraud orders must be based on facts supported by evidence as to the fraudulent nature of the enterprise concerned and may not be based merely upon his personal belief that the scheme is fraudulent. A fraud order was held unlawfully issued against a concern which claimed to cure disease by the influence of the mind because "there is no exact standard of absolute truth by which to prove the assertion false and a fraud. . . We may not believe in the efficacy of the treatment to the extent claimed by the complainants, and we may have no sympathy with them in such claims, and yet their effectiveness is but a matter of opinion in any court." American School of 
United States Supreme Court ${ }^{69}$ have held that Congress enjoys power under the constitution to pass the legislation in question, which does not after all differ in principle from the acts relating to obscene literature and lotteries.

4. Prize Fight Films. By a statute passed in 1912 it is made a criminal offense to import from abroad for purposes of public exhibition pictures or moving picture films of prize fights or to send them in or to receive them from interstate commerce or the mails. ${ }^{70}$ The only litigation to date respecting the validity of this act concerns the provision against importation. ${ }^{71}$ There can be no doubt whatever that that portion of the act which authorizes the exclusion from the mails would be sustained by the Supreme Court should its constitutionality be questioned.

5. Seditious and Treasonable Publications. It will be recalled that one of the reasons which led England and other countries to make their post offices government monopolies was the desire to use the mail facilities for an official espionage on private correspondence with a view to discovering who were the enemies of the sovereign or his ministers. ${ }^{72}$ It is quite natural that this

Magnetic Healing v. McAnnulty, (1902) 187 U. S. 94, 47 L. Ed. 90, 23 S. C. R. 33.

The problem of the finality of the action of the postmaster general in issuing fraud orders is touched upon in a general article by Professor T. R. Powell entitled, Conclusiveness of Administrative Determinations in the Federal Government, Amer. Pol. Sci. Rev., Aug. 1907, p. 583.

For criticism of the broad powers conferred upon the postmaster general by this legislation see Pierce, Federal Usurpation, p. 354.

68 New Orleans Nat'l Bank v. Merchant, (1884) 18 Fed. 841 ; Hoover v. McChesney, (1897) 81 Fed. 472; United States v. Loring, (1884) 91 Fed. 881 . 789.

69 Public Clearing House v. Coyne, (1903) 194 U. S. 497, 24 S. C. R.

70 Act of July 31, 1912, 37 Stat. at L. 240.

71 Weber v. Freed, (1915) 239 U. S. 325, 60 L. Ed. 308, 36 S. C. R. 131. See Cushman, op. cit., 3 Minnesota Law Review 392.

72 Hemmeon points out that the proclamation of 1591 making the British foreign post a monopoly was issued "in order that the government might be able to discover any treasonable or seditious correspondence," History of British Post Office, 190. Freund states: "In a royal grant of the office of postmaster to foreign parts (July 19, 1632, XIX Rymer"s Foedera 385) the monopoly is justified by the consideration, how much it imports to the state of the King and this realm that the secrecy thereof be not disclosed to foreign nations, which cannot be prevented if a promiscuous use of transmitting or taking up of foreign letters and packets should be suffered.' Cromwell spoke of the Post Office as the best means to discover and prevent dangerous and wicked designs against the commonwealth," Police Power, Sec. 666, note. See also May, Constitutional History of England, II, 245 ff.

"The post office is no longer regarded in England as a means of detecting conspiracies. Letters passing through the mails may nevertheless be opened on the warrant of the secretary of state, but the occurence is 
early purpose should not be entirely forgotten even in those countries in which the secrecy of the mail is now preserved, and that in critical times efforts should be taken to prevent the use of mail facilities for treasonable or seditious purposes. ${ }^{73}$ No government can be expected to lend positive aid to those who are seeking to accomplish its destruction. It would, of course, be unnecessary to forbid specifically the use of the mails for the actual execution of a treasonable plot or conspiracy. ${ }^{74}$ In time of war, however, the United States government has taken steps to prevent the circulation through the mails of matter which would tend even indirectly to interfere with the success of the military preparations or campaigns of the government. During the Civil War the exclusion of objectionable matter from mails was carried on by the executive arm of the government ${ }^{75}$ without the authority of any statute but with the acquiescence of Congress. ${ }^{76}$ While there was protest from those subjected to this treatment, ${ }^{77}$ there seems to have been no litigation arising from these executive acts, which were apparently regarded as part of the military policy of the government. ${ }^{78}$ When the Obscene Literature Act of 1872 was passed Congress included in its description of proscribed matter "any letter upon the envelope of which, or postal card upon which scurrilous epithets may have

very rare, and would be sanctioned by public opinion only in extreme cases." Cooley's Blackstone, Book I, 323, note.

${ }_{73}$ See provisions of the recent Trading with the Enemy Act establishing a censorship of foreign mail and forbidden communications to foreign countries during the period of the war except through the mails. Act of Oct. 6, 1917, 40 Stat. at L. 412.

74 "The overt act of putting a letter into the post office of the United States is a matter that Congress may regulate. . . . Intent may make an otherwise innocent act criminal, if it is the step in a plot." Badders v. United States, (1916) 240 U. S. 391, 36 S. C. R. 367.

75 These exclusions do not seem to have been carried out by the post office department exclusively. This power was exercised by the secretary of state on some occasions. This officer withdrew mail privileges from the New York Staats Zeitung and from the National Zeitung (New York) in 1861. Official Records of War of Rebellion, 2nd Series, Vol. 2, 494, 501. For instances of such exclusion of newspapers from the mails by military authority see Sen. Doc. No. 19, 37 Cong., 3d Sess. The writer is indebted to Professor James G. Randall for this data.

${ }^{76} \mathrm{An}$ investigation into the alleged arbitrary acts of the postmaster general was conducted in 1862 and 1863 by the Judiciary Committee of the House of Representatives. The power claimed by the postmaster general was sustained by the committee and no action was taken. Burgess, The Civil War and the Constitution, II, 222-3.

${ }_{77}$ An editorial in the New York World for August 18, 1864, denounced the espionage upon private correspondence by postal authorities.

${ }^{78}$ See the valuable article by Professor James G. Randall, "The Newspaper Problem in Its Bearing upon Military Secrecy During the Civil War, (1918) 23 Am. Hist. Rev., 303. 
been written or printed or disloyal devices printed or engraved thereon." 79 When this act was amended and broadened in scope the next year, however, the phrase relating to "disloyal devices" was omitted. ${ }^{80}$ The first effective legislation which Congress enacted dealing with this problem is found in the Espionage Act of $1917 .{ }^{81}$ In addition to its general prohibitions the law provides that any mail matter which is in violation of any provisions of the statute is non-mailable, that any matter "urging treason, insurrection, or forcible resistance to any law of the United States, is hereby declared non-mailable." A heavy penalty is inflicted upon those who use or attempt to use the mails for the transmission of any matter thus declared non-mailable. ${ }^{82}$ In 1918 this act was amended so as to extend to the postmaster general during the period of the war authority to order all mail matter to be withheld from persons who, "upon evidence satisfactory to him," he concludes are using the mails in violation of any of the provisions mentioned above. ${ }^{83}$

This legislation has been much discussed both from the standpoint of public policy and from that of constitutional law. It seems clear, however, that most of the attacks which have been made upon it have been directed in reality not so much at the validity of the statute itself as at the administration of it and its proper applicability to concrete cases. On the point of constitutional power to pass the acts in question there can be no serious disagreement. The Obscene Literature Acts and the Anti-Fraud Acts afford clear precedents; and the lower federal courts which have passed upon the constitutionality of these clauses of the Espionage Act have uniformly upheld them. ${ }^{84}$

\section{Denial of Postal Facilities Used for Violating Federal} Law. In at least two of the statutes which have been mentioned, Congress has legislated upon the theory that it was proper to refuse to allow the postal facilities to be used as an agency in the violation of federal law. The Anti-Frand Act at the present time includes within its prohibitions the use of the mails to dis-

${ }^{79}$ Act of June $8,1872,17$ Stat. at L. 302.

80 Act of March 3, 1873, 17 Stat. at L. 599.

81 Act of June 15, 1917, 40 Stat. at L, 230.

82 The provision in the Trading with the Enemy Act for the licensing by the postmaster general under direction of the president of foreign language newspapers is not primarily a postal regulation, since the right was denied to unlicensed papers not merely to mail but to publish or circulate in any other way. Act of Oct. 6, 1917, 40 Stat. at L. 425.

${ }^{83}$ Act of May 16, 1918, 40 . Stat. at L. 553.

84 Masses Publishing Co. v. Patten, (1917) 244 Fed. 535; same. (1917) 245 Fed. 102; Jeffersonion Publishing Co. v. West, (1917) 245 Fed. 585. 
pose of, circulate, or procure counterfeit money or securities of the United States. ${ }^{85}$ Congress possesses, of course, adequate power to punish the counterfeiting of its own currency and securities and those of foreign countries and has long since exercised this power ${ }^{88} \mathrm{By}$ the provision dealing with the transmission of counterfeit money or securities through the mails, Congress has merely refused to permit the United States Post Office to act as an unwitting accomplice of those committing or intending to commit a crime against the laws of the United States. In the same way it will be recalled Congress made it unlawful to transmit through the mails any matter which was in violation of any provision of the Espionage Act. ${ }^{87}$ Upon the same theory rests the statutory provision declaring non-mailable any publication which violates any copyright granted by the United States. ${ }^{88}$

It would, of course, be possible to expand very greatly the amount of this type of legislation and there have been proposals from time to time to that effect. ${ }^{89}$ It would be entirely possible to penalize the use of the mails as an aid in the violation of the prohibition amendment, the Sherman Act, or for the purpose of soliciting unlawful campaign contributions in congressional elections. It is difficult to imagine any offense against the United States government in the furtherance of which the criminal might not make use of the facilities of the postal service. The power of Congress to punish the use of the mails for these unlawful purposes seems to be quite unassailable. As a matter of practical expediency, however, this sort of legislation is not apt to be resorted to unless the systematic use of the postal facilities is so vital to the accomplishment of the crime that under normal circumstances the post office affords a more or less effective means for its detection or prevention..$^{90}$

${ }^{85}$ Supra, note 61.

86 These prohibitions are to be found in Chapter VII of the United States Criminal Code, Act of March 4, 1909, 35 Stat. at L. 1115.

${ }^{87}$ Supra, p. 417. It is also made a criminal offense to send through the mails any threats against the life of the president of the United States. The same provision penalizes the making of such threats orally or in any other way. Act of Feb. 14, 1912, 39 Stat. at L. 919.

${ }^{88}$ Act of March 3,1879, 20 Stat. at L. 359. Section 320 of the Criminal Code makes it a penal offense to import from abroad through the mails any publication which violates copyright laws or infringes rights accruing thereunder. Act of March 4, 1909, 35 Stat. at L. 1083.

89 It has been proposed, for example, to penalize the use of the mails for the purpose of securing false witnesses, suborning perjury and like offenses. A bill to this effect was introduced in the Senate in 1917. See Sen. bill 2523, Cong. Rec., June 27, 1917, Vol. 55, p. 4337.

90 No useful purpose would be served by making it a crime to mail a letter in furtherance of such an offense against the criminal laws of the 


\section{The Question of Constitutionality}

The foregoing analysis has sketched briefly the principal types of statutes by which Congress has sought to prevent the federal postal system from being used as a means of distributing injurious matter or of aiding the consummation of injurious and illicit transactions. In every case in which the constitutionality of any of these acts has been passed upon by a court it has been sustained; and there can be no doubt but that those acts which have not been subjected to judicial scrutiny rest upon the same or equally firm constitutional grounds. The very unanimity with which the courts have declared that Congress has not gone too far in enacting these laws has, of course, precluded the making of any authoritative judicial pronouncement as to just how far Congress may still go in the exercise of this power. The question whether Congress has exhausted its authority in this particular legislative field remains open for speculation. It is a question which may conveniently be dealt with under two headings: first, the constitutional basis for the power now under consideration; this will involve a review of the various theories advanced in support of that power; and second, the constitutional limitations within which the power must be exercised. Consideration of these two problems may aid in reaching a conclusion as to whether Congress may go still further in prohibiting the use of the mails as an agency for evil or undesirable ends, or in encouraging such use for purposes beneficial to the public welfare.

1. Constitutional Basis of Legislation. Opinions regarding the power of Congress to exclude different classes of things from the mails range all the way from the view that Congress has no power to exclude anything which was mailable at the time the federal constitution was formed ${ }^{91}$ to the equally extreme view that Congress may exclude from the mails anything it pleases. ${ }^{92}$ But the theories on which the right of exclusion has most commonly been sustained are two in number.

United States as peonage, or piracy, or other crimes where the use of postal facilities would form a rare or very minor means of criminal accomplishment.

01 "So long as the duty of carrying the mails is imposed upon Congress, a letter or a packet which was confessedly mailable matter at the time of the adoption of the constitution, cannot be excluded by them, provided the postage be paid and other regulations be observed." Brief for defendants in Ex parte Jackson, (1877) 96 U. S., 727, 24 L. Ed. 877. The view was expressed, however, that matter which had become mailable since that time could be excluded.

${ }^{92}$ See infra, p. 421. 
(a) In the first place, there has been a general recognition of the fact that a very special duty and responsibility rests upon Congress to protect the public from certain types of evils or injuries to which the very existence of an efficient postal system would otherwise expose them. As has been pointed out elsewhere, Congress has long since recognized and assumed a similar responsibility in respect to foreign and interstate commerce. ${ }^{93}$ If Congress possesses such police power by reason of its authority over a commerce which it does not create but merely regulates, it cannot be doubted that equal or even greater authority would be derived from the power to "create" or "establish" a postal system. It may be urged, in fact, that while the constitutional authority arising from the commerce and postal clauses is ample in both cases to support this type of legislation, a much stronger moral obligation rests upon Congress to protect the public health, morals, safety, and general welfare from the misuse of the mails than from the misuse of the facilities of interstate commerce. Two considerations support this view. The first is that the responsibilities arising from the fact of creation, ownership, and operation of an institution may be reasonably regarded as greater than those arising from a poyer merely to "regulate" a system or institution which Congress did not create, does not own nor operate, and cannot destroy. The second is that the ordinary individual is in a much better position to protect himself from the misuse of interstate commerce than from the misuse of the mails. This is due to the essential differences between the two systems. Under normal circumstances the participation of the individual in the transactions of interstate commerce and his relations to interstate carriers result from a voluntary contractual relationship. Spurious or even harmful products may be sent to him, but rarely without his having bargained for the shipment of any products at all. A very different situation exists with respect to the postal system. At practically negligible cost to the sender, grossly indecent letters or papers could be brought several times a day to the door of any person by an employee of the United States government and this without the previous knowledge and against the wishes of the recipient. Without depriving himself of all the conveniences arising from the regular visits of the postman a person might be quite unable to protect himself against this sort of abuse. It is not unreasonable to

${ }^{93}$ Cushman, op. cit., 3 Minnesota Law Review $381 \mathrm{ff}$. 
assert that the governmental authority which thus penetrates daily the very homes of the people must recognize a commensurate duty of protecting those homes from the distribution of noxious matter. Even those who have been solicitous that the national government should not attempt to extend its authority over subjects commonly left to state control have looked upon the sort of national police regulations now under consideration as not only harmless but highly desirable. ${ }^{94}$ Assuming for the sake of argument that every citizen enjoys a well-protected constitutional right to the unrestricted and equal use of the mails, it would be useless to argue that the regulations in question unconstitutionally abridge that right, since no one can be said to have a right to circulate matter which is injurious to the public health, morals, or safety. ${ }^{95}$ Most of the court decisions in which the validity of this type of legislation has been considered have laid strong emphasis upon the right and duty of Congress to protect the public welfare from the abuse of mail privileges. ${ }^{96}$

(b) There are those, however, who go beyond this admittedly conservative view of the power of Congress to exclude various types of matter from the mails which has just been discussed. They take the position that Congress may not only make it unlawful to send through the mails such things as are dangerous to health, morals, or safety, either intrinsically or in the use to which they are to be put, but may also deny mail privileges to things or to transactions which do not conform to congressional views of public policy. In other words, the power of exclusion is held to extend not only to things which are actually or potentially injurious or dangerous but to those the circulation of which in the judgment of Congress would be undesirable or unwise. ${ }^{97}$

94 See discussion of Mr. Bryan's views on this point, infra p. 436.

95 Lottery Case, (1903) 188 U. S. 321, 23 S. C. R. 321, 47 L. Ed. 492 ; Hoke v. United States, (1913) 227 U. S. 308, 33 S. C. R. 281, 57 L. Ed., 523.

96 United States v. Journal Co., (1912) 197 Fed. 415; Knowles v. United States, (1909) 170 Fed. 409; In Jeffersonion Publishing Co, $:$ West, (1917) $245 \mathrm{Fed} .585$, the court said in respect to the exclusion of mail matter in violation of the Espionage Act, "Had the postmaster general longer permitted the use of the postal system which he controls for the dissemination of such poison, it would have been to forego the opportunity to serve his country afforded by his lofty station."

97 An extreme statement of this view is found in the argument for the government in Lewis Publishing Co. v. Morgan, (1913) 229 U. S. 288, 57 L. Ed. 1190,33 S. C. R. 867.

It was stated in substance that the postal power is one which "conveys an absolute right of legislative selection as to what shall be carried in the mails, and which therefore is not in any wise subject to judicial control, 
The considerations advanced in support of this position may be briefly reviewed.

At the outset it must be admitted that Congress in establishing a postal system must of necessity determine what is to be regarded as mail matter and what is not. Obviously not everything need be transmitted through the mails unless the post office is to perform all the functions of a common carrier. This necessity of determining what shall constitute mail matter carries with it the power and duty of setting up classifications as to various types of matter. No positive obligation rests upon the government to carry any particular class of articles. Should Congress decide that nothing but sealed letters of a certain size and weight may be sent through the mails, there could be no doubt of its constitutional authority so to legislate. The Supreme Court has recognized that Congress in establishing a postal system may properly set up classifications of matter in respect to mailing privileges.

"In establishing such a system, Congress may restrict its use to letters and deny it to periodicals; it may include periodicals and exclude books; it may admit books to the mails and refuse to admit merchandise; or it may include all of these and fail to embrace within its regulations telegrams or large parcels of merchandise, although in most civilized countries of Europe these are also made a part of the postal service." 98

This power of classification arises from the fact that Congress creates, owns, and operates the postal system and that in exercising this power of classification Congress may properly give effect to its own conceptions of public policy. Its position is that of a proprietor; and it is under no obligation to lend the use of its property for purposes which it regards as unwise and undesirable, nor is it prohibited from extending the use of its mail facilities on especially favorable terms to those who will make use of them for the promotion of constructive ideas of public policy. In short, Congress may not only discourage certain uses of the mails which it deems contrary to public policy but it may also stimulate and encourage other uses of the mails which it regards as helpful or beneficial to the national welfare. From the practical point of view, the latter method would of the two seem to

even although in a given case it may be manifest that a particular exclusion is but arbitrary, because resting on no discernable distinction, nor coming within any discoverable principle of justice or public policy."

98 Public Clearing House v. Coyne, (1903) 194 U. S. 497, 48, L. Ed. 1092, 24 S. C. R. 789. 
be easier of execution as well as less open to criticism; and Congress has employed it in numerous instances. The most conspicuous examples are the special privileges extended to periodical literature under the statutes creating second class mailing privileges, ${ }^{99}$ the extension of the franking privilege to the speeches of members of Congress printed in the Congressional Record, ${ }^{100}$ and the act providing for the free transmission through the mails of reading matter printed in raised characters for the use of the blind. ${ }^{101}$

If it is true that the relationship of the government to the post office partakes largely of proprietorship, it would follow that the use of the mail service by the individual is a privilege rather than a constitutional right. ${ }^{102}$ This seems to be recognized by the decisions of the courts either directly or by implication. ${ }^{103}$ It constitutes an important difference between the rights of the individual to engage in interstate commerce and to use th? mails. There is without question a constitutionally protected rig'st of the ci izen to engage in interstate commerce, subject, of course, to such rules and provisions as Congress may impose by virtue of its power to regulate that commerce. ${ }^{104}$ Congress may control the exercise of that right; but it may not destroy it entirely. ${ }^{105}$ The postal facilities, however, come into being only at the discretion of Congress; and neither the refusal of Congress to create them or expand them nor its complete withdrawal of them would violate an affirmative right guaranteed by the constitution. ${ }^{108}$ It was this distinction between the relation of the individual to the postal service and to interstate commerce which the Supreme

99 Act of March $3,1879,20$ Stat. 359 and subsequent amendments.

100 Act of March 3, 1875, 18 Stat. at L. 343 .

101 Act of April 27, 1904, 33 Stat. at L. 313 permits the free transmission of literature in raised characters to and from public institutions or libraries. Act of Aug. 24, 1912, 37 Stat. at L. 551 extended the privilege to all periodicals in raised characters irrespective of destination.

102 For valuable theoretical discussion of distinction between "rights" and "privileges," see Hohfeld, Fundamental Legal Conceptions as Applied in Judicial Reasoning, (1913) 23 Yale Law Journal 16.

103 People's U. S. Bank v. Gilson, (1905) 140 Fed. 1, 5; Missouri Drug Co. v. Wyman, (1904) 129 Fed. 623.

104 United States v. Del. \& Hudson Co., (1908) 164 Fed. 215, reversed on other grounds in 213 U. S. 366.

103 There is no decision of the Supreme Court squarely on this point since Congress has never tried to exercise such power of destruction. The reasoning of the Supreme Court in United States v. Del. \& Hudson Co., supra, certainly lends support to this view.

100 "A citizen of the United States as such has a right to participate in foreign and interstate commerce, to have the benefit of the postal laws - Cooley, Principles of Constitutional Law, 273. Italics are the writer's. 
Court apparently had in mind in the Jackson case, when, after upholding the authority of Congress to exclude lottery circulars from the mails, it declared : ${ }^{107}$

"But we do not think that Congress possesses the power to prevent, the transportation in other ways, as merchandise, of matter which it excludes from the mails."

This important distinction between a privilege and a right is one which is clearly recognized in our constitutional law; and there is plenty of precedent and authority for the view that in dispensing privileges which it has a right to withhold entirely the government may classify the recipients in order to give effect to its views respecting public policy, even though such classifications would be open to constitutional attack if applied to those enjoying a constitutional right. In the disposal of public lands. Congress may properly pursue a constructive policy of encouraging homestead development. ${ }^{108}$ Aliens seeking admission to the United States or seeking the privileges of American citizenship may be classified by Congress in ways which would seem arbitrary if the persons subjected to such discriminations had any constitutional right to demand of this government the thing they were seeking. ${ }^{109}$ It is well established that since no one has a right to perform work for the United States government Congress may provide that those who do enjoy that privilege may be subjected to the requirement of the eight-hour day for employees, ${ }^{110}$ although the right of a state to establish a general eight-hour day for all labor as an exercise of the police power must still be regarded as open to the most serious question. ${ }^{111}$ The establishment of similar classifications by the various states in respect to public work has been sustained. ${ }^{112}$ The United States Supreme Court has held, in fact, that while a state may not under its

107 (1877) 96 U. S. 727, 735, 24 L. Ed. 877.

108 See the Homestead Act of May 20, 1852, and subsequent legislation of similar nature.

${ }^{109}$ See pamphlet, "Naturalization Laws and Regulations" revised to October 10, 1919, published by United States Dept. of Labor. It is not intended to suggest, however, that aliens applying for citizenship may not be classified along lines much more arbitrary than would be permissible if they were citizens applying for some other privilege.

110 Act of Aug. 1, 1892, 27 Stat. at L. 340, upheld in Ellis v. United States, (1906) 206 U. S. 246, 51 L. Ed. 1047, 27 S. C. R. 600.

${ }_{111}$ This would seem to be suggested by the fact tnat regulations of the hours of labor are still upheld, if at all, mainly upon grounds of protection to health. See Bunting v. Oregon, (1917) 243 U. S. 426, 37 S. C. R. 435,61 L. Ed. 830 upholding the Oregon Ten Hour Law. It is doubtful if an eight hour law could be sustained on this basis. 148.

112 Atkin v. Kansas, (1903) 191 U. S. 207, 24 S. C. R. 124, 48 L. Ed. 
police power prevent the employment of aliens by private employers of labor, ${ }^{113}$ it may discriminate against aliens when it comes to work done for the state itself. ${ }^{114}$ The right to contract freely with other persons for the performance of labor is a right which cannot be denied by the state; but the right to be employed on the public work of the state itself is not a right at all, but a privilege.

Enough has been said to make clear that the power of Congress over the postal system is broader and more complete than over an institution or a system in respect to which its relation is not that of creator, owner, and operator. It is equally obvious that the so-called right of the individual to use the mails is not a right guaranteed to him by the constitution, such as the right to engage in interstate commerce or the right to be tried for crime only by a jury of his peers; it is a privilege the length and breadth of which is determined by a congressional discretion broad enough to allow general considerations of public policy to dictate the terms upon which it may be enjoyed.

It would, however, be entirely erroneous to assume that because Congress may for reasons of public policy set up classifications as to the purposes for which it is willing to allow the postal service to be used, it may make any and all classifications it chooses, no matter how arbitrary. The fact that Congress is under no constitutional compulsion to create a postal system at all does not mean that it may refuse to transmit in the system it has created the literature of one religious sect, or a particular political party. If it allowed the mailing of letters at all, it could not exclude love-letters and admit letters relating to the business of coal-mining. This is, of course, merely to say that although in the exercise of its power over the postal system Congress may give effect to its views of public policy, it must at all times keep its legislation within certain constitutional limits. The character and operation of those constitutional limits may now be examined.

\section{Constitutional. Limitations ÚPON Legislation ${ }^{115}$}

In classifying the uses and purposes to which it is willing to extend the privileges of the mails, Congress is subject to two im-

113 Truax v. Raich, (1915) 239 U. S. 33, 36, S. C. R. 7, 60 L. Ed. 131. 78.

114 Heim v. McCall, (1915) 239 U. S. 175, 60 L. Ed. 200, 36 S. C. R.

115 The constitutional prohibition in the fourth amendment against unreasonable searches and seizures (supra, p. 410) is of course a limitation 
portant constitutional limitations. One of these is the prohibition against the passing of any law abridging the freedom of religion or the press $;^{\mathbf{1 1 6}}$ the other is the more general prohibition against deprivation of liberty or property without due process of law. ${ }^{117}$

1. Freedom of Religion and the Press. It must be borne in mind that Congress is forbidden by the first amendment to the constitution not merely to interfere by direct and positive action with freedom of religion and of the press, but it is forbidden also to use its granted powers in such a way as to abridge those fundamental rights. ${ }^{118}$ It does not matter, therefore, how absolute or unlimited the power of Congress over the postal service might be, that power cannot be exercised to abridge religious freedom or to limit the freedom of the press. It does not, however, follow that no restraint may be placed upon the circulation of matter through the mails because of a possible abridgment of these rights. Neither freedom of religion nor freedom of the press is an absolute and unqualified right which may be set up against every conceivable governmental encroachment. They are both alike subject to reasonable restrictions in the interests of the public safety and morals and general welfare. ${ }^{119}$ Religion may not act as a cloak to protect polygamy from being attacked as subversive of public morals; and the exclusion from the mails of matter designed to promote the spread of polygamy on grounds of religion could no more be attacked as an abridgment of religious freedom than could a direct law which suppressed polygamy entirely as immoral be attacked as such an abridgment. ${ }^{120}$ So also the same power which justifies the penalizing of treasonable or seditious utterances or publications would naturally extend to the denial of mail facilities to matter of this character, nor could there be alleged any interference with the freedom of the press: ${ }^{121}$

upon every exercise of the postal power. This point need not be further discussed as it has no peculiar bearing upon the topic under consideration. 116 "Congress shall make no law respecting an establishment of religion, or prohibiting the free exercise thereof; or abridging the freedom of speech or of the press. . . " U. S. Const. Amendment I.

117 "Nor shall any person . . be deprived of life, liberty, or property, without due process of law." U. S. Const. Amend. V.

118 Monogahela Navigation Co. v. United States, (1893) 148 U. S. 312, 336, 13 S. C. R. 622, 37 L. Ed. 463.

${ }_{119}$ Freund, Police Power, Secs. 467, 468; Willoughby, Constitution, II, 841 ; Hall, Constitutional Law, 90.

120 Reynolds v. United States, (1878) 98 U. S. 145, 163, 25 L. Ed. 244.

121 In Schenck v. United States, (1919) 249 U. S. 47, 39 S. C. R. 247, the Espionage Act was upheld by the Supreme Court as against the criti- 
If, however, Congress should attempt to exclude from the mails the literature devoted to the propagation of Christian Science or Catholicism, or if it should enact that sectarian journals should be transmitted free or at lower rates than other religious periodicals, there is no doubt but that such legislation would be held to violate the freedom of religion. ${ }^{122}$ In like manner, if a Republican Congress should exclude Democratic campaign literature from the mails or refuse to carry it on equal terms with other matter of the same class, there would no less certainly be a denial of freedom of the press. What the precise outside limits may be on the power of Congress to make postal regulations affecting the two fundamental rights under discussion is a question which is not easy to answer. It is a question, however, a detailed discussion of which is beyond the limits of this article. ${ }^{123}$ It may in general be said that postal regulations excluding matter from the mails or establishing a preferred class of mail matter and founded upon a sound basis of public policy cannot be successfully attacked under the first amendment unless there is manifest in such legislation an intention unjustifiably to abridge the freedom of religion or of the press or unless such would be the natural result of its operation. ${ }^{124}$

2. Due Process of Law. While the declaration in the fifth amendment that Congress shall not deprive any person of life, liberty, and property without due process of law is less definite in meaning than the prohibitions upon congressional power which have just been discussed, it is a no less effective limitation upon Congress in the exercise of all its delegated powers including the postal power. It might on casual thought be urged that since the government is under no obligation to provide any mail facilities at all for the use of the people, no person could conceivably

cism -among others that it unduly abridged freedom of speech. No case involving the exclusion of seditious publications from the mails has thus far been decided by the Supreme Court.

122 "There is not complete religious liberty where any one sect is favored by the state and given an advantage by law over other sects." Cooley, Constitutional Limitations (7th Ed.) 663.

${ }^{123}$ Cooley, Constitutional Limitations, Ch. 12; Rogers, op. cit. 98 ff. See also Rogers, "Federal Interference with the Freedom of the Press," 23 Yale Law Journal 559. A valuable discussion of this point is also contained in Chafee, Freedom of Speech in War Time, (1919) 32 Harvard Law Review 932.

124 "In excluding various articles from the mails, the object of Congress has not been to interfere with the freedom of the press, or with any other rights of the people; but to refuse its facilities for the distribution of matter deemed injurious to the public morals." Ex parte Jackson, (1877) 96 U. S. 727, 24 L. Ed. 877. 
claim that he had been deprived of liberty or property by a statute which forbade him the right to use the mails for a specified purpose. This theory rests upon the supposed axiom that the greater power must include the lesser; and that the power to withhold all mail privileges must therefore include the power to withhold some or all of those privileges for any reason whatsoever or for no reason at all. There is a certain plausibility to this argument which arises from the fact that a private person engaged in a purely private business certainly does possess exactly this power and may discriminate amongst his patrons or among those to whom he desires to extend any privilege in any manner which seems to him desirable. ${ }^{125}$

It is hardly necessary to point out, however, that the government as a dispenser of privileges which may constitutionally be withheld does not enjoy the arbitrary and uncontrolled discretion just alluded to. While a person may not be in a position to compel the government to extend a privilege at all, he does have a constitutional right to enjoy it on equal terms with others who stand in the same general relation to the government as he does. It may not be a "liberty" within the meaning of the due process clause to be able to mail a letter or a book provided nobody else can do so. But if the government has created facilities for mailing letters and books it is a "liberty" within the meaning of the due process clause to use those facilities on equal terms with other persons in the same class. ${ }^{126}$ It is in this sense of the word that the use of the postal system has been declared to be part of the "liberty" secured by the fourteenth amendment against deprivation without due process of law. ${ }^{127}$ In short, the due process clause operates as a limitation upon the power of Con-

${ }^{125} \mathrm{~A}$ soon as a business comes to take on a public character or becomes "affected with a public interest" this arbitrary power of the proprietor to discriminate amongst his patrons ceases to exist.

${ }^{126}$ It seems clear that the "equal protection of the law" or protection against arbitrary discrimination is an essential part of the guarantee of due process of law. "Due process of law within the meaning of the Amendment is secured if the laws operate on all alike, and do not subject the individual to an arbitrary exercise of the powers of government." Giozza v. Tiernan, (1893) 148 U. S. 657, 13 S. C. R. 721, 37 L. Ed. 599. Freund, Police Power, Sec. 611. See 6 Ruling Case Law, Sec. 367, 437; 12 Corpus Juris 1190.

127 Allgeyer v. Louisiana, (1897) 165 U. S. 578, 41 L. Ed. 832, 17 S. C. R. 427. Cf. Statement in Hoover v. McChesney, (1897) 81 Fed. 472. "We think the right to use the mails though in degree much less valuable than the use of the transportation lines, would be equally a property right, and one which could not be taken away without due process of law." 
gress to make classifications which are arbitrary in character in respect to the enjoyment of mail privileges. ${ }^{128}$

This calls for a brief discussion of what sort of classification is to be regarded as arbitrary; for quite obviously many classifications are not only legitimate but necessary. While there has been a great deal of difficulty in deciding in concrete cases the precise character of the equality of treatment to which persons are constitutionally entitled, there is substantial agreement with reference to certain tests by which the validity of statutory classifications is to be-judged. No one will question, in the first place, that no classification would be constitutional in which the members of the class singled out for distinctive treatment dic. not differ in some substantial manner from those not included in such class. ${ }^{129}$ Congress is not apt to violate this principle in classifying mailing privileges. But if one could imagine a requirement that letters going from New York to Chicago should pay three cents postage while those going from Chicago to New York should pay two cents postage, or a requirement that morning newspapers should enjoy postal privileges denied to evening papers, there would be no hesitancy in concluding that such classifications rested upon no discernible differences between those inside and outside the class created. In the second place, there is equally unanimous agreement that when a class is created by law, the basis of classification must bear some reasonable relation to the object sought to be accomplished by the act which creates it. ${ }^{130}$ Congress could not, for example, provide that newspapers printed in foreign languages should be forbidden to circulate obscene matter but that papers printed in English should be exempt from such prohibition. Such discrimination would be void because the basis of the classification, namely, the language

128 This view is supported by analogy in the rule which restricts the right of states or municipalities to discriminate in favor of union labor employed on public work. This is held a denial of the equal protection of the law even though no one has a right to work for the state. Miller v. Des Moines, (1909) 143 Ia. 409, 122 N. W. 226, 21 Ann. Cas. 207. 23 L. R. A. (N.S.) 815 ; Fiske v. People, (1900) 188 I11. 206, 58 N. E. 985. 52 L. R. A. 291.

128 Seaboard Air Line Ry. v. Seegars, (1907) 207 U. S. 73, 52 L. Fd. 108, 28 S. C. R. 28; Deyol v. Superior Court. (1903) 140 Cal. 476. 74 Pac. 28, 98 A. S. R. 73; Ritchie v. Wyman, (1910) 244 111. 509, 91 N. E. 695,27 L. R. A. (N.S.) 994.

130 American Sugar Refining Co v. Louisiana, (1900) 179 U. S. 89. 45 L. Ed. 102, 21 S. C. R. 43 : Atchison, etc., R. Co. v. Matthews, (1899) 174 U. S. $96,105,43$ L. Ed. 909.19 S. C. R. 609 ; Kane v. Erie R. R. Co., (1904) 133 Fed. 681,67 C. C. A. 653,68 L. R. A. 788 ; Chicago, etc., R. Co. v. Westly, (1910) 178 Fed. 619, 102 C. C. A. 65. 
in which newspapers are printed, bears no relation whatever to the purpose which the statute seeks to serve, the suppression of the circulation of indecent matter through the mails. It is not enough that the distinction which marks the line of classification is one which may properly be made the basis of class legislation; there must be a relevancy between the basis of the classification and the particular purpose of the statute which creates that classification. ${ }^{131}$

These two protections against arbitrary class legislation have, however, a broader application to the classification of mailing privileges than the somewhat extreme illustrations used above would suggest. It must at all times be borne in mind that the power which Congress is exercising in setting up these classifications is, after all, the power derived from the clause authorizing the establishment of post offices and post roads. Statutes which aim to protect the national health, safety, and morals by excluding various things from the mails are postal regulations first and police regulations second. It follows, therefore, that when a person is forbidden to use the postal service for a certain purpose, he has a right to demand that the basis of classification bear a reasonable and substantial relationship not primarily to the general welfare of the country but to such aspects of the general welfare of the country as may properly be affected by Congress in the exercise of its postal power. When the Supreme Court declared that a postal regulation in order to be constitutional must treat alike "those who stand in the same relation to the government," 132 it meant the "same relation" in respect to the power of the government to exercise the postal authority and not in respect to liability to military service, the payment of federal taxes, or any other irrelevant consideration.

This leads, then, to a brief consideration of what the tests of relevancy must be between the postal power of Congress and the classifications of postal privileges which Congress may set up for the purposes of formulating national public policy and exercising a national police power. There can be no doubt that any classification which aimed at the protection of the postal system from injury or obstruction or was designed to promote its efficiency would rest upon a basis intiniately and immediately

131 State v. Loomis, (1893) 115 Mo. 307, 22 S. W. 350, 21 L. R. A. 789; State v. Currens, (1901) 111 Wis. 431, 87 N. W. 561, 56 L. R. A. 252.

${ }_{132}$ Public Clearing House v. Coyne, (1903) 194 U. S. 497, 48 L. Ed. 1092, 24 S. C. R. 789. 
connected with the postal power. It is equally certain that discriminations which sought to protect the public from the circulation through the mails of noxious or dangerous matter or from the consummation of injurious transactions which thrive on postal facilities would also bear a definite relation to the postal power. In neither of these cases could one complain that he had been subjected to discrimination the basis of which was irrelevant to the postal power. It is the belief of the writer that Congress may go still further and may set up classifications in respect to the use of postal facilities which are based merely upon congressional ideas of public policy when that public policy is one which is related to the development of functions which a postal system may naturally and reasonably be expected to perform or of interests which it may properly be used to promote. The postal service must be regarded not merely as an agency which exists for the purpose of performing messenger boy service for individuals but as an institution which actively and positively promotes the spread of intelligence as to current affairs, as well as to other matters of general interest. This is the basis upon which the special second class mail privileges are to be justified, although the Supreme Court has expressed its belief that the conferring of these privileges was "at least in form, a discrimination against the public generally." 133 In other words, the discrimination rested upon a basis definitely related to a public policy or benefit which it was natural and proper for Congress to promote through its postal system. It was in this light that the Supreme Court viewed the regulations imposed upon newspapers and periodicals by the Newspaper Publicity Act of 1912.134 One of the provisions of this statute will be discussed at a later point $;^{135}$ but it may be noted here that the prohibitions placed upon publications enjoying second class mailing privileges against printing editorial or other reading matter for which money is received without marking it "advertisement" are regarded by the Court as part and parcel of the congressional policy that the privileges thus extended to publications should be used primarily

${ }^{133}$ Lewis Publishing Co. v. Morgan, (1913) 229 U. S. 288, 304, 57 L. Ed. 1190,33 S. C. R. 867.

It is on this basis that the special mailing privileges accorded literature for the blind (supra p. 1423) may be sustained: They serve to aid the dissemination of intelligence amongst a group otherwise restricted in respect to such advantages.

134 Act of August 24, 1912, 37 Stat. at L. 553.

135 Infra, p. 438. 
for the "dissemination of information regarding current events" and only incidentally for the circulation of advertising matter. It is, therefore, the kind of requirement that may properly be imposed. ${ }^{136}$ But should Congress attempt to promote in this manner a public policy unrelated to the natural and customary functions and purposes of the postal system, a classification so founded would be arbitrary and unreasonable and would in consequence violate due process of law,- as well as be an exercise by Congress of a power not conferred by the constitution.

By way of summary it may be suggested that by classifying the uses to which it will allow the mails to be put, Congress exercises a generous police power for the protection of the public welfare from such evils as would be fostered and promoted by an entirely unrestricted use of postal privileges. It also enables Congress to promote a constructive public policy in respect to such matters as fall within the range of national interests which the postal system may properly be expected to serve. In short, these classifications may be established to prevent the misuse and to promote the most beneficial use of the postal service. But any discrimination in respect to mail privileges, no matter how commendable in purpose, which is not based upon some actual difference between the classes created in their. relation not to the national welfare but to the postal service, would be arbitrary and unconstitutional.

\section{Regulations Denying the Use of Mails for Purposes of Violating or Evading State Law}

It would seem fairly clear that if Congress may with propriety classify the uses to which the postal system may be put for the purposes which have just been examined, it would be equally legitimate to provide that those facilities should not be used for the purpose of evading or violating state law. Legislation analogous in character has been sustained as a proper exercise by Congress of the power to regulate interstate commerce, ${ }^{137}$ upon principles applying with equal or greater force to postal power.

The first proposal to adopt such a regulation of the mails seems to be that made by Calhoun at the time of the famous

${ }^{136} \mathrm{Cf}$. statement of Cooley: "The power to establish postoffices includes everything essential to a complete postal system under federal control and management, and the power to protect the same by providing for the punishment as crimes of such acts as would tend to embarrass or defeat the purpose had in view in their establishment." Principles of Constitutional Law, 95.

${ }_{137}$ The Webb-Kenyon Act. See Cushman, 3 Minsesota Law Review $406 \mathrm{ff}$. 
controversy in 1836 as to the power of Congress to exclude from the mails incendiary and abolitionist publications. ${ }^{138}$ Believing that the absolute exclusion from the mails of the objectionable matter would abridge the freedom of the press, Calhoun proposed it should be made unlawful for any postmaster to receive and send on through the mails any publication addressed to a destination in which its circulation was unlawful. It was made a penal offense to deliver such mail matter to any person not authorized by the local authorities to receive it. ${ }^{139}$ This bill was amended so as to make it unlawful for any postmaster to deliver publications the circulation of which was forbidden by local law. ${ }^{140}$ The bill failed of passage; but the discussions in Congress upon its constitutionality were long and interesting. ${ }^{141}$

It has already been seen that the second statute excluding matter relating to lotteries from the mails confined its prohibition to "letters or circulars concerning illegal lotteries, so-called gift concerts, or other similar enterprises." ${ }^{142}$ The purpose here seems to have been to make the illegality of the transmission of this matter contingent upon the illegality under state law of the enterprise to which it related. Such transmission would be unlawful even though lotteries might not be prohibited either in the state in which the circulars were mailed or in the state into which they were sent. In other words, the law would be violated by sending from one state to another in both of which lotteries were lawful, matter relating to a lottery in a remote state where such an enterprise was forbidden. This is not a case, therefore, in which matter is excluded from the mails because of the illegality of its origin ${ }^{14 s}$ nor because it is to be used for unlawful purposes at its destination, ${ }^{144}$ but because the enterprise which

${ }^{138}$ On December 2, 1835, President Jackson had sent a message to Congress urging the passing of legislation to prevent the circulation through the mails in the slave states of abolitionist literature. It was felt that such reading matter might stir up slave insurrection. Richardson, Messages and Papers of the Presidents, III, 177. This called forth extended discussion of the entire problem.

13912 Debates of Cong. 383.

14012 Debates of Cong. 1720.

14112 Debates of Cong. 26-23, 1103-1108, 1136-1153, 1155-1171. For a summary of this discussion see Rogers, op. cit., 103-115, Willoughby, op. cit., II, 786.

142 Act of June 8, 1872, 17 Stat. at L. 283.

143 For legislation based on this principle see the Lacey Act of May $25,1900,31$ Stat. at L. 188, which excludes from interstate commerce game killed in violation of state law. See Cushman, op cit., 3 MrnneSOTA LAW REVIEW 408.

${ }_{144}$ As is the case in the Webb-Kenyon Act and the act excluding liquor advertisements from the mails when addressed to states forbidding their circulation. See note 146 infra. 
certain staites have forbidden is of such a character that it thrives definitely and immediately upon the circulation through the mails of matter advertising and promoting it, no matter what the precise locality may be in which that circulation takes place. The act would, therefore, seem to fall squarely within the general principle of the legislation aimed to prevent the mails being used as an agency for the violation of state law.

Finally Congress has applied this same principle in its recent act making unlawful the sending by mail of liquor advertisements into states in which it is unlawful to advertise or solicit orders for intoxicating liquor. ${ }^{145}$ While this act differs somewhat from the Webb-Kenyon Act, the question of its constitutionality probably would be settled by the doctrine of the case in which the earlier legislation was sustained. ${ }^{146}$ Its constitutionality has not thus far been questioned. ${ }^{147}$

\section{Proposals that Conformity to General Police Regu- lations Be Made Price of Enjoyment of Mail Facilities}

In the discussion thus far there have been considered the various classifications of postal privileges based upon the nature of the matter excluded or the character of the uses to which the postal facilities were to be put. A discussion of the police power which Congress may exercise under the postal clause would be incomplete without some comment upon the proposals which have sometimes been made that postal facilities should be withheld entirely or in large part from persons who would not conform to various congressional mandates in respect to public policy and national welfare. It is perfectly obvious that there is a great difference between forbidding any person to send obscene literature through the mails and forbidding any person who publishes

145.Act of March 3, 1917, 39 Stat. at L. 1069.

146 The Webb-Kenyon Act made it unlawful to ship intoxicating liquors in interstate commerce which are "intended, by any persons interested therein, to be received, possessed, sold, or in any manner used" in violation of the laws of the state of their destination. There was no penalty, however, for violation; violators merely being placed at the mercy of the state authorities. Violation of the Liquor Advertisement Act is made a crime against the United States punishable by fine or imprisonment. The validity of the Webb-Kenyon Act was upheld by the Supreme Court in Clark Distilling Co. v. Western Maryland Ry Co., (1917) 242 U. S. 31. 61 L. Ed. 326, 37 S. C. R. 180. See, Cushman, op cit., 3 MinneSOTA LAw REviEw $406 \mathrm{ff}$.

147 For discussion of power of states to pass laws preventing various uses of the United States mails, see Rogers, op. cit., Ch. 5. 
obscene literature to use the mails for any purpose whatsoever. In the first case Congress prevents a misuse of postal facilities; in the second case Congress withholds postal privileges as a sort of penalty for non-compliance with the congressional policy for the suppression of obscene literature. It makes conformity to certain police requirements a condition precedent to the enjoyment of the use of the mails.

While no statute of this type has yet been passed by Congress, the desirability of enacting such laws has more than once been urged in recent years by those whose views as to the constitutional propriety of such legislation should be accorded respectful consideration. Perhaps the most conspicuous of these proposals and the one most widely discussed was the one made by the Pujo Money Trust Committee in 1913. This congressional committee proposed as a means of regulating and controlling stock exchange speculation "that Congress prohibit the transmission by the mails or by telegraph or telephone from one state to another of orders to buy or sell quotations or other information concerning transactions on any stock exchange, unless such exchange shall be a body corporate of the state or territory in which it is located" and unless it comply with other specified conditions. ${ }^{148}$ While the denial of mail privileges herein proposed was not absolute, it was nevertheless very substantial. The substance and effect of the proposed law was to penalize stock exchanges which refused to incorporate under the laws of any state by denying them mail privileges which were accorded to others. One writer has proposed a law similar in principle which would exclude from the mails papers of any corporation which refused to make full reports to the federal government respecting those aspects of its affairs in regard to which Congress desired full publicity. ${ }^{149}$ Dean J. P. Hall expresses the view that "as a last resort, Congress might deny the privileges of the mails to businesses, which, though operating wholly within a state, persisted in practices that Congress within a reasonable discretion saw fit to disapprove." ${ }^{150}$

148 Majority Report of the Committee to Investigate the Concentration of Money and Credit (February 28, 1913).

See Rogers, op. cit., 161 ff.

149 Pamm, Powers of Regulation Vested in Congress, (1910) 24 Harv. L. Rev. 77.

${ }_{150}$ This yiew is based on the authority of the Lottery Cases which Dean Hall says rested upon the ground that "Congress could regulate interstate commerce for any purpose not forbidrlen by the constitntion. not merely for purposes granted by the constitution," (1912) 20 Journal of Political Economy 473. 
Mr. Bryan, in a newspaper debate with Senator Beveridge in 1907 , in which he appeared as the champion of states rights, expressed the belief that Congress could properly deny all mail privileges to monopolistic corporations or trusts. ${ }^{151}$ In the autumn of 1918 two bills were introduced into Congress providing for a similar denial of postal privileges to those who employed children below a certain age. ${ }^{152}$

At the outset of any discussion of the constitutionality of this type of legislation, it would probably be admitted that Congress could deny mail privileges to persons as a penalty for crime. If Congress may constitutionally punish a criminal by depriving him of his citizenship, surely it could impose the lesser penalty of taking away a specific incident to that citizenship. It would make no difference what the offense was which was so punished, provided only that Congress had the constitutional authority to prohibit it and provided the denial of mail privileges was imposed as other criminal penalties are imposed after conviction in a court having jurisdiction. The imposition of such a penalty in any other manner would, of course, be a denial of liberty and property without due process of law. It would clearly be a type of authority which could not be delegated to an administrative officer. ${ }^{153}$ It may have been this rule which prompted the cautious language of the Supreme Court in sustaining the power conferred upon the postmaster general to refuse to deliver registered mail matter to persons shown to be using the mails for fraudulent purposes. The law authorized the withholding of all such mail, and not merely such as pertained to the fraudulent transactions. After commenting on the practical impossibility of determining whether sealed mail matter is innocent or not, the court went on to say:154

"It is true it may occasionally happen that he [the postmaster general] would detain a letter having no relation to the

151 "Congress has power to control interstate commerce, and the decision of the Supreme Court in the Lottery Case leaves little doubt that that power can be so exercised as to withdraw the interstate railroads and telegraph lines and the mails from the corporations which control enough of the product of any article to give them an actual monopoly." The Reader, Vol. 9, p. 356.

152 Sen. bills 4732, 4760, June 27, 1918, introduced by Mr. Kenyon. Cong. Rec., Vol. 56, 8341 .

153 Interstate Commerce Commission v. Brimson, (1894) 154 U. S. $447,485,38$ L. Ed. 1047,14 S. C. R. 1125,155 U. S. 3, 39 L. Ed. 49 ; Wong Wing v. United States, (1896) 163 U. S. 228, 234, 41 L. Ed. 140, 16 S. C. R. 977; Whitcomb's Case, (1876) 120 Mass. 118, 21 Am. Rep. 502.

154 Public Clearing House v. Coyne, (1903) 194 U. S. 497, 48 L. Ed. 1092,24 S. C. R. 789. 
prohibited business; but where a person is engaged in an enterprise of this kind, receiving dozens and perhaps hundreds of letters every day containing remittances or correspondence connected with the prohibited business, it is not too much to assume that, prima facie, at least, all such letters are identified with such business. . . . Whether, in case a private registered letter was thus seized and detained, and damage was thereby occasioned to the addressee, an action would lie against the postmaster general, is not involved in this case."

The Court seened to view with disfavor a construction of the law which would place in the hands of an administrative officer the power to deny to a person the right to receive innocent mail matter because he was found to be using the mails for forbidden purposes. Such a power would savor of the imposition of a penalty for crime by the postmaster general, whereas crime can legally be punished only by a court of law. ${ }^{155}$ It is the belief of the writer that the power exercised by the postmaster general to exclude permanently from second class mail privileges publications in the issues of which he has found non-mailable matter within the meaning of the Espionage Act, is open to various serious questions on the grounds just mentioned. It is one thing to allow an administrative officer the power to exclude non-mailable publications; it is a very different thing to allow him to keep on excluding the subsequent issues of such publications when in actual fact they might prove to be innocent in character. ${ }^{156}$ Such procedure raises, to say the least, a very close question of due process of law.

With such legislative proposals as those mentioned at the beginning of this section, however,-laws in which the denial of mail privileges is imposed as a penalty for acts of omission or commission which Congress has no power to punish directly, - the

155 A like construction would presumably apply to the clause of the Espionage Act conferring similar authority upon the postmaster general. ${ }_{158}$ The grounds upon which the postmaster general bases the propriety of his action in these cases are set forth by him as follows: "To be a 'newspaper or other periodical publication' within the meaning of the law governing second-class matter a publication must among other requirements, be composed in its entirety of mailable matter. A publication containing matter which is nonmailable is not a newspaper or other periodical publication' within the meaning of the law and therefore is not entitled to the second-class mail privilege. In administering the law governing second-class matter it has been found necessary to revoke the second-class mail privilege of some publications for the reason that their contents consisted more or less of matter which was nonmailable and which, therefore, removed them from the class of publications entitled under the law to that privilege." Report of the Postmaster General, 1917. p. 65 . 
question of constitutionality assumes a very different form. This is not so much the imposing of a penalty in the technical sense of the word as the setting up of an antecedent or even a continuing condition as the price of the enjoyment of mail privileges. The price of the privilege of using the mails is the abandonment of child labor, or the cessation of monopolistic practices, or the filing of reports regarding corporate business and activities. The test in the light of which the validity of these acts must be judged is, in the last analysis, the relevancy of the conditions thus imposed to the postal power and the interests and functions for the promotion of which that power may be used. This seems to be the test applied by the Supreme Court to the provision of the Newspaper Publicity Act of 1912 which denies the privileges of the mails to publications which fail to comply with the requirements of the law in respect to printing semi-annually certain facts respecting their ownership and control. ${ }^{157}$ In passing upon the validity of this act, the Supreme Court, after holding that the denial of nail privileges mentioned should be construed to mean second class privileges only, pointed out that the condition imposed on the publishers was intimately connected with the purposes for which second class mail privileges had been created and that it was within the scope of the postal power to extend those privileges "upon condition of compliance with regulations deemed by that body incidental and necessary to the complete fruition of the public policy lying at the foundation of the privileges accorded."158 The implication is clear that if the condition thus imposed had not been thus related to the public policy which Congress under the postal power could properly promote, it would have been void. ${ }^{159}$

If the conditions thus imposed as the price of the enjoyment of mail privileges are not thus relevant to the purposes of the postal power, as would seem to be the case with the proposed child labor law, the statutes creating them could be attacked

157 Act of August 24, 1912, 37 Stat. at L. 553.

158 Lewis Publishing Co. v. Morgan, (1913) 229 U. S. 288, 57 L. Ed. 1190,33 S. C. R. 867.

${ }_{159}$ The brief for the government had alleged that Congress possessed the most arbitrary power to classify mail privileges. See supra, note 197. The court concludes its opinion in this case with the following statement: "Finally, because there has developed no necessity of passing on that question, we do not wish even by the remotest implication to be regarded as assenting to the broad contentions concerning the existence of arbitrary power through the classification of the mails, or by way of condition, embodied in the proposition of the government which we have previously stated." 
upon two grounds. It could be urged, in the first place, that such laws were not in reality exercises of the postal power at all because the use of the mails has nothing whatever to do with the evil of the child labor which it is the object of the legislation to remedy. ${ }^{160}$ In the second place, such a statute would fail to meet the tests of due process of law. What has already been said upon the subject of due process of law in its application to arbitrary classifications of mail matter ${ }^{161}$ would apply with equal force to the classifications established by the acts now being considered. When persons are classified in respect to their privileges in the mails upon the basis of their employment or non-employment of children, they may properly urge that that classification is arbitrary and a denial of due process of law. It may further be suggested that the Supreme Court has declared in a well known case ${ }^{162}$ that a person is deprived of due process of law by being obliged to sacrifice a constitutional right as the price of securing a privilege which the government might withhold entirely in its discretion. This principle would seem to be applicable by way of analogy to the case of one who, as a condition of enjoying the privileges of the mails which Congress need not extend to any one, is required to do something which Congress could not make him do, or cease doing something which Congress could not forbid. ${ }^{163}$ It is the belief of the writer that the Supreme Court would not hesitate to declare such legislation unconstitutional on either or both of the grounds which have been mentioned.

\section{Conclusion}

It seems clear from the foregoing analysis that the postal power is one which may be wielded very effectively by Congress for the police purposes. That power extends to the adequate protection of the postal service from injury; it extends to the protection of the public from the various dangerous or harmful

${ }^{160} \mathrm{It}$ was urged by the proponents of the Keating-Owen Act that there was a substantial relationship between child labor and interstate commerce for the reason that child labor "feeds" on interstate commerce and is stimulated thereby. For discussion of this point, see Cushman, op. cit., 3 Minnesota Law Review $471 \mathrm{ff}$. The connection between child labor and interstate commerce and the postal system is certainly much less substantial than between child labor and interstate commerce.

161 Supra, p. 427.

162 Western Union Telegraph Co. v. Kansas, (1910) 216 U. S. 1, 54 I. Ed. 355,30 S. C. R. 355.

${ }^{163}$ For development of this point, see Green. The Child Labor Law and the Constitution, Illinois Law Bulletin, April, 1917. p. 17; also Beck, Nullification by Indirection, (1910) 23 Harv. L. Rev. 441. 
uses to which mail privileges may be put; it extends to the promotion of positive public policies related to the broad purposes for which the postal system exists; it extends to the withholding of postal privileges as a means of inducing persons to conform to reasonable requirements and regulations incidental to the privileges of the mails. But as soon as Congress begins to use its postal power as a lever or a club to compel people to do things or refrain from doing things which have no real or intimate relation to the postal system or any of the larger purposes which may properly be promoted by it, the line of constitutionality has been crossed and Congress has exceeded its powers. In exercising a police power under the postal clause, as under the powers to tax and to regulate commerce, the ultimate test of constitutionality must be, not whether the police regulation established is necessary or desirable for the protection of the national health, safety, or morals, but whether the evil which Congress is combatting has any real and practical connection with the particular delegated power which Congress is employing. Any other construction of the authority of Congress to exercise a police power would destroy the whole force of the doctrine of delegated national powers and allow Congress by a process of the most obvious indirection to deal with problems of purely local welfare. 



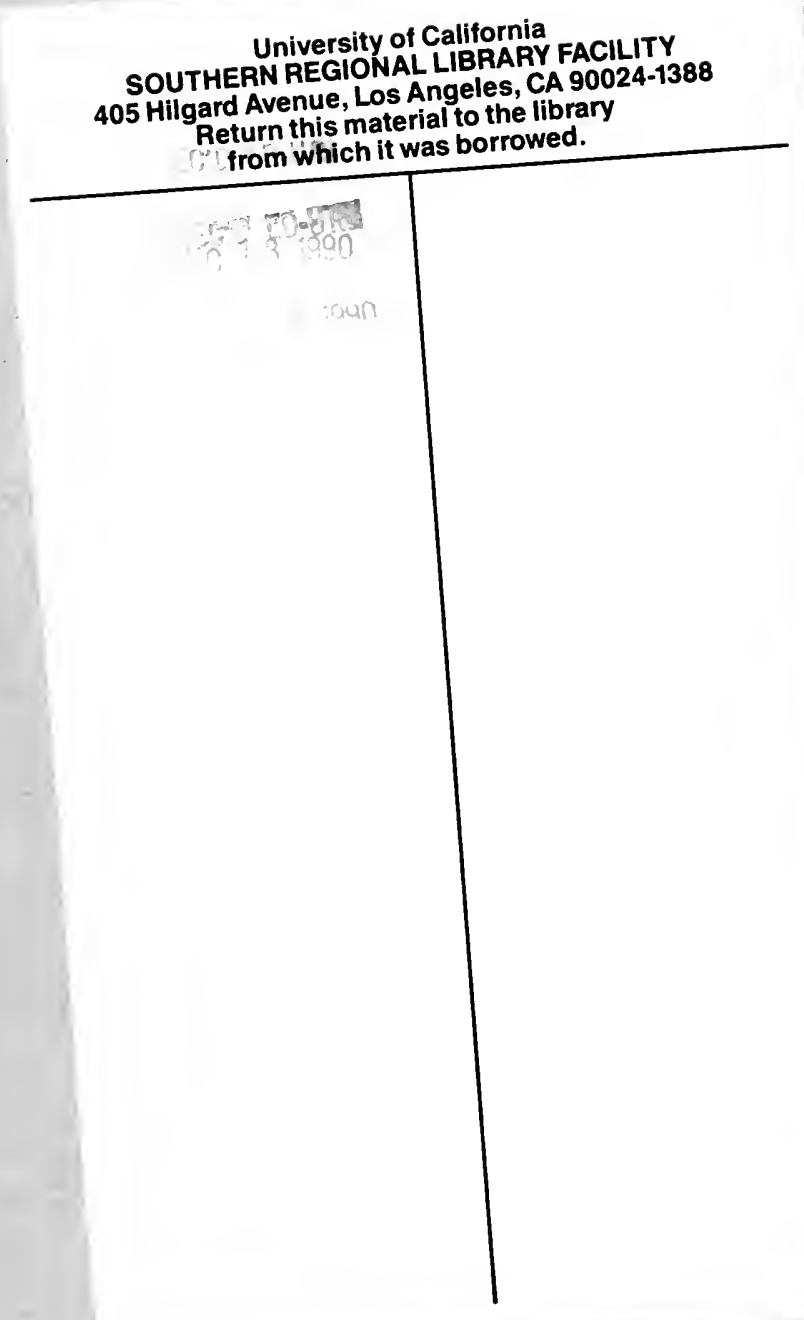


ar

A 000688360

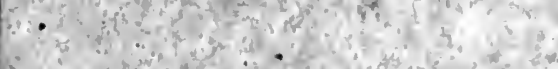

S.4.

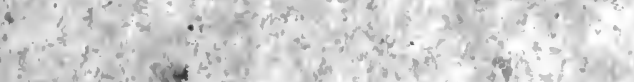

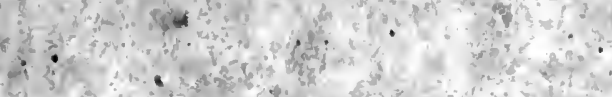

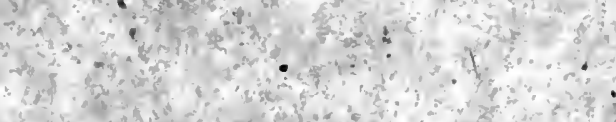

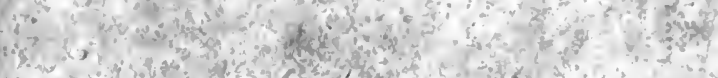

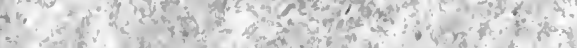

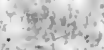

$7 \mathrm{~L}^{2} \mathrm{y}^{4}$

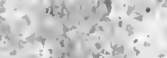

of $3(x)+3$

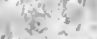

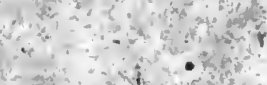

a

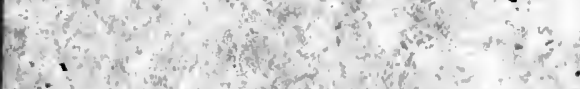

.

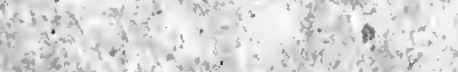

(a)

the 6

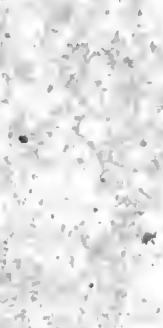


in:
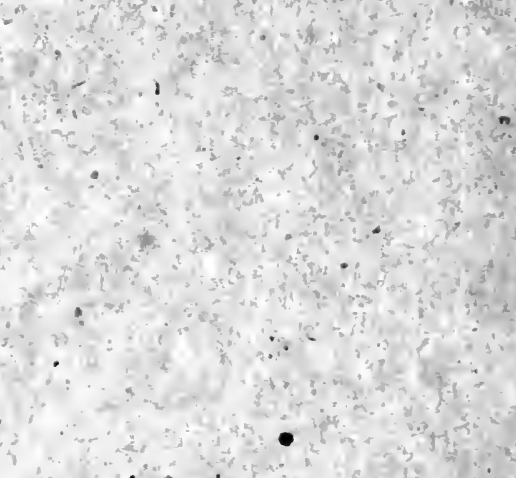